\title{
Engürüs Seferi ve Estergon Muhafazasına Katılan Geri Hizmet Birliklerine Ait 1685 Tarihli Defter
}

\author{
Zülfiye Koçak* - Dragana Amedoski**
}

\begin{abstract}
$\ddot{O} z$
II. Viyana seferinin başarısızlıkla sonuçlanması Osmanlı Devleti'nin batıdaki imajına zarar vermiş ve Avrupalı devletlerin Osmanlı Devleti'ne karşı kutsal ittifak anlaşması imzalamalarına neden olmuştu. Bu ittifaktan sonra Osmanlı Devleti, batıda birden fazla cephede mücadele etmiş ve en zorlu mücadelesini Avusturyalılara karşı yürütmüştü. Macaristan topraklarına hâkim olma düşüncesi çatışmaların temel nedenini oluşturmaktaydı. Bu süreçte Osmanlının, II. Viyana bozgunundan sonra Macaristan bölgesinde yürüttüğü en önemli faaliyetlerden biri Engürüs Seferi'ydi. Bu çalışmada Cumhurbaşkanlığı Devlet Arşivleri Başkanlığı Osmanlı Arşivi'nde Maliyeden Müdevver Defterler arasında 7723 numarayla kayıtlı bulunan ve Engürüs Seferi ve Estergon muhafazasında Serasker ve Vezir-î azam İbrahim Paşa'nın maiyetinde bulunan Lağımcı, Beldar ve Neccar isimlerini ihtiva eden defterin transkripsiyonu ve tıpkıbasımı verilecektir. Bu geri hizmet birlikleri 23 Zi'l-hicce 1096/20 Kasım 1685 ile gurre-i Ra (Rebiü'l-evvel) 1097/26 Ocak 1686 tarihleri arasında toplanmış ve kayda geçirilmiştir.
\end{abstract}

Anahtar Kelimeler: Engürüs, Osmanlı Devleti, Geri Hizmet Birlikleri, Estergon, 17. yüzyı1

\section{Record of Service Units Dated to the Ungurus Campaign and Siege Esztergom in 1685}

\begin{abstract}
The failure of the Second Siege of Vienna had disrupted the image of the Ottoman Empire in the West resulting in signing The Holy Alliance Treaty by the European states against the Ottomans. Following this alliance, the Ottoman Empire fought in more than one front in the West, while the most difficult struggle was the one led against the Austrians. The thought of controlling the lands of Hungary was the main reason for these conflicts. The Ungurus campaign was among the most important activities of the Ottomans in the Hungary region after the defeat in the Second Siege of Vienna. In this work, the transcription and facsimiles of the census no. 7723 which is kept in the Ottoman Archive Division in the Directorate of State Archives, Maliyeden Müdevver Defterler, will be given. This source includes the names of Lağımc1, Beldar and Neccar who took part in

* Doç. Dr., Bitlis Eren Üniversitesi, Fen-Edebiyar Fakültesi, Tarih Bölümü, Bitlis/TÜRKIYE, zkocak@beu.edu.tr ORCID: 0000-0002-1352-9849 DOI: 10.37879/belgeler.2021.1

** Dr., Belgrat Tarih Enstitüsü, Belgrat/SIRBIISTAN, draganaamedoski@yahoo.com ORCID: 0000-0002-7645-5832
\end{abstract}


Ungurus campaign and the Siege of Esztergom in the employ of the Seraskier and the Grand Vizier Ibrahim Pasha. These service units were drafted and recorded in the period from 23 Zi'l-hicce 1096/November 20, 1685 to gurre-i Ra (Rebiü'l-evvel) 1097/ January 26, 1686.

Keywords: Ungurus, Ottoman Empire, Esztergom, Service Brigade Units, $17^{\text {th }}$ century.

\section{Giriş}

II. Viyana kuşatmasının başarısızlıkla sonuçlanması Osmanlı Devleti'nin içinde bulunduğu durumu zorlaştırmış ve başarısızlığın nedeni olarak görülen Merzifonlu Kara Mustafa Paşa'nın idamına neden olmuştu ${ }^{1}$. Merzifonlu'nun yerine vezir-i azam olan İbrahim Paşa ${ }^{2}$, yaptığ1 faaliyetlerle durumunu sağlamlaştırmaya çalışırken, Osmanlıyı Avrupa'dan atma zamanının geldiğine kanaat getiren Papanın teşvikiyle Avrupa-Hıristiyan Birliği oluşturulmuştu. Papanın Osmanlılara karşı barıştırdığı Leh kralı ve Avusturya imparatoruna, 1684 yılında Venedik üçüncü ortak olarak katılmıştı. Yüzyılın sonlarında, savaşın bitmesine yakın da Rusya bu birliğe dahil oldu. Adı geçen devletler aralarındaki anlaşmazlıkları bir kenara bırakarak Osmanlı Devleti'ne karşı topyekûn bir savaş başlattılar³. Bu durum İbrahim Paşa'yı endişelendirmiş ve kendisi cephelere gitmekten kaçınarak buralara serdarlar göndermeyi tercih etmişti ${ }^{4}$.

Osmanlı Devleti'nin ittifaktan sonra savaşmak zorunda kaldığı en sıkıntılı cephe Avusturya cephesi olmuştu. Macaristan tarafına Bekri Mustafa Paşa serdar tayin olundu. Yeni serdar, Belgrad sahrasında Diyarbekir Beylerbeyi Şeytan İbrahim Paşa ile buluşarak, Budin'e gitme kararı aldı. Avusturyalılar çok sayıda asker ve mühimmatla Ciğerdelen'e oradan Estergon'u geçerek Vişegrat'a ve son olarak da Vaç üzerine yürüdüklerinde Bekri Mustafa Paşa, Budin Beylerbeyi Kara Mehmed Paşa’yı serasker olarak görevlendirdi. Düşman, Peşte kalesini kuşattıktan sonra Bekri Mustafa Paşa kuvvetlerini Budin civarında yenilgiye uğrattı. Yenilginin ardından Osmanlı askeri Hamza Bey Palangası'na çekilmek zorunda kalınca Budin düşman tarafından kuşatıldı. Mustafa Paşa, Hamza Bey Palangası'nda iken düşman taarruzuna uğradı ancak askerinin bir kısmı savaştan geri çekilince Ösek tarafına geçilme zorunluluğu ortaya çıktı ${ }^{5}$.

1 Mustafa Nuri Paşa, Netâyic ül-Vukuat, (Sad. Neşet Çağatay), C I-II, Türk Tarih Kurumu Basımevi, Ankara 1992, s. 284; Silahdâr Fındıklı1ı Mehmed Ağa, Silâhdâr Târîhi, II. Cild, Orhaniye Matbaası, İstanbul 1928, s. 119-121; Râşid Mehmed, Târih-i Râşid, I, İstanbul 1865, s. 429; Abdülkadir Özcan, "Mehmed IV", Türkiye Diyanet Vakfi İslam Ansiklopedisi, C XXVIII, İstanbul 2000, s. 416.

2 Kara İbrahim Paşa'nın hayatı ve faaliyetleri hakkında daha detaylı bilgi için bk. Taib Ahmed Osmanzade, Hadikatü'l Vüzera, Ceride-i Havadis Matbaası, İstanbul 1271, s. 110; Silahdâr Fındıklılı Mehmed Ağa, Silâhdâr Târîhi, I. Cild (1065-1094), İstanbul Devlet Matbaası 1928, s. 652-653; İsmet Parmaksızoğlu, "İbrahim Paşa, Kara İbrahim Paşa”, İslam Ansiklopedisi, C V/II, Milli Eğitim Basımevi, İstanbul 1968, s. 906-908; Yunus Özger, "Sadrazam Kara İbrahim Paşa Vakıfları”, Tarih İncelemeleri Dergisi, C XXIII/S. 2, (Aralık 2008), s. 109-150; Abdülkadir Özcan, "İbrahim Paşa, Kara”, DİA, XXI, İstanbul 2000, s. 329-330.

3 Kemal Çiçek, “II. Viyana Kuşatması ve Avrupa'dan Dönüş (1683-1703)”, Türkler, C IX, Ankara 2002, s. 750; Bu ittifaktan sonra Osmanlı Devleti'nin Lehistan, Venedik ve Avusturya mücadeleleri için bk. Silahdâr Mehmed Ağa, Silâhdâr Târîhi, II, s. 126-138 ve 234-235.

4 Mustafa Nuri Paşa, age., s. 285; Özcan, "İbrahim Paşa", s. 329.

5 Silahdâr Mehmed Ağa, Silâhdâr Târîhi, II, s. 134-141. 
Budin kuşatması sırasında Budin Valisi Kara Mehmed Paşa hayatını kaybedince onun yerine Şeytan İbrahim Paşa getirildi. Avusturyalılar, İbrahim Paşa'dan Budin Kalesi’nin teslimini istediler. Ancak cevap olumsuz olunca 4 Ekim 1684'te umumi saldırıya geçtiler. Saldırı İbrahim Paşa'nın gayretleriyle bertaraf edildiğinden Avusturya muhasarayı kaldırmak zorunda kaldı. Elde edilen başarıdan dolayı Şeytan İbrahim Paşa'nın lakabı Melek olarak değiştirildi ${ }^{6}$. Melek İbrahim Paşa'nın Budin müdafaası şöhretinin parlamasına ve bu yüzden Engürüs serdarlığına layık görülmesine yol açmıştı. Lakin Sadrazam Kara İbrahim Paşa, onun bu halinden rahatsız olup aleyhinde çalışmaya başlad1 ${ }^{7}$. Kışı Belgrad'da geçiren Serdar İbrahim Paşa, askeri Zemun sahrasında toplamışsa da Vezir-î azam Kara İbrahim Paşa' dan yeterli asker ve mühimmat yardımı alamayınca eksik levazımatla harekete geçmeye mecbur olmuştu. 1685 yılında Uyvar Kalesi'nin Avusturyalılar tarafından kuşatıldığı haberi üzerine Budin önlerine gelen İbrahim Paşa, Uyvar yolunda ilerlemenin zorluğunu göz önüne alarak işgal altındaki Estergon'un kurtarılmasına karar verdi ${ }^{8}$. Ancak Osmanlı ordusunun kalelere dağılmış olması sebebiyle yanında az bir kuvvet bulunmakla birlikte harp levazımı da eksikti. Eksikliklerin giderilmesini talep ettiyse de Budin müdafaası dolayısıyla onun kazandığı itibardan rahatsız olan Sadrazam Kara İbrahim Paşa, istenilen yardımları yerine getirmedi. Buna rağmen yeni serdar, 1 Ağustos 1685 günü Estergon'u kuşattı. Diğer taraftan Uyvar'1 muhasara eden Avusturya Kumandanı Lotheringen, Melek İbrahim Paşa'nın az bir kuvvetle Estergon üzerine yürüdüğünü haber alınca Uyvar önünde 20.000 kişilik bir kuvvet birakarak geri kalan birliklerini dük de Lorraine komutasında Estergon üzerine sevk etti ${ }^{9}$. Avusturya ordusu kuşatmanın 15. gününde Osmanlı askerini bir hile ile yenilgiye uğrattı ${ }^{10}$. Bu arada Uyvar Kalesi de düşmüş, Estergon civarındaki irili ufaklı birçok yerleşim birimi kaybedilmiş, İbrahim Paşa'nın Avusturya generali nezdindeki barış girişimi imparator istemediğinden sonuçsuz kalmışt $1^{11}$. Bu olayların ardından Ösek’e gelen Melek İbrahim Paşa'nın Edirne'den gönderilen erzakı açık alana yı̆̆ması, bu erzakın da Macarlar tarafından yakılması, hakkında bazı dedikoduların çıkmasına sebep oldu. Kışı geçirmek üzere geldiği Belgrad'da bulunduğu sırada Avusturyalıların, Rumeli Beylerbeyi Çelebi İsmail Paşa'nın kışlağı olan Arad Palankası'nı yağmalamaları İbrahim Paşa'nın Budin muhafızlığındaki şöhretine gölge düşürdü. 28 Kasım 1685 günü padişah huzurunda yapılan toplantıda İbrahim Paşa'nın 100.000'i aşkın askerle Estergon Kalesi'ni alamama, Avusturyal1lara yenilip pek çok mühimmatın telefine sebep olma, Uyvar Kalesi’ni yardımsız bırakıp göz

6 Şemseddin Sami, Kâmûs al-a 'lâm, Mihran Matbaası, İstanbul 1306, s. 560-561; Silahdâr Mehmed Ağa, Silâhdâr Târihi, II, s. 160-179 ve 184-185.

7 Mustafa Cezar, Mufassal Osmanlı Tarihi Resimli-Haritall, C IV, Türk Tarih Kurumu Yayınları, Ankara 2011, s. 2170.

8 Abdülkadir Özcan, “İbrahim Paşa, Melek”, Dİ, C XXI, İstanbul 2000, s. 336.

9 Ahmet Şimşirgil, Kayı VI Osmanlı Tarihi Imparatorluğun Zirvesi ve Dönüş, Timaş Yayınları, İstanbul 2014, s. 317-318.

10 Silahdâr Mehmed Ağa, Silâhdâr Târîhi, II, s. 211-213; Defterdar Sarı Mehmed Paşa, Zübde-i Vekayiât Tahlil ve Metin (1066-1116/1656-1704),( Haz. Abdülkadir Özcan), Türk Tarih Kurumu, Ankara 1995, s. 203.

11 Dimitri Kantemir, Osmanlı Imparatorluğu'nun Yükseliş ve Çöküş Tarihi, III, Kültür Bakanlığ1 Yayınları, Ankara 1979, s. 103-105. 
göre göre düşmana kaptırma, gönderilen erzakın Ösek’te yakılmasına sebep olma, merkezin haberi olmadan Avusturyalılarla barış girişiminde bulunma gibi suçlarla itham edilmişti ${ }^{12}$ ve 3 Aralık 1685 tarihinde idam edilmişti ${ }^{13}$.

Budin cephesinde bu olaylar olurken Macaristan ve Mora cephelerindeki savaşlar Osmanlı aleyhine gelişmiş, birçok kale ve şehir elden çıkmıştı. İbrahim Paşa serhat kalelerine sadece erzak, asker ve mühimmat sevkiyle yetinmiş ${ }^{14}$ ve cephelerde gerçekleşen başarısız durumların padişaha duyurulmaması için özel çaba sarf etmişti ${ }^{15}$. Bu davranışlar kendisine karşı olanların temayüllerini arttırmış ve nihayetinde 18 Aralık 1685 tarihinde sadrazamlıktan azledilmiştir ${ }^{16}$. Kara İbrahim Paşa'nın azlinde, fukara ve mazlumların yaşadıklarını bildirmek için Edirne’ye akın etmelerinin etkili olduğu belirtilir ${ }^{17}$. Sadaretten azledilen Kara İbrahim Paşa bir süre İstanbul'da yaşadıktan sonra bütün emlak ve serveti müsadere olunarak, Rodos'a sürgün edildi (Şubat 1686). Bir müddet sonra da, Recep Paşa'nın ısrarı üzerine idamına ferman alınarak, kapıcı başı Mustafa Bey vasıtasıyla Mayıs 1687'de idam edildi' ${ }^{18}$.

II. Viyana bozgunundan sona gelişen olaylar ve Osmanlı Devleti'nin Avusturya cephesi hakkında verilen bu kısa açıklamadan sonra çalışmaya konu olan defter hakkında bilgi verilmesi uygun görülmüştür.

\section{I-MAD. d. 7723 Numaralı Defterin Muhtevası}

Başbakanlık Osmanlı Arşivi’nde Maliyeden Müdevver Defterler arasında 7723 numarayla kayitlı bulunan defter, II. Viyana bozgunundan sona Osmanlı Devleti'nin Avusturya cephesinde yürüttüğü Engürüs Seferi’ne ve Estergon muhafazasına katılacak serasker ve vezir-î azam İbrahim Paşa'nın maiyetinde sefere katılan Lağımcı, Beldar ve Neccar isimlerini ihtiva etmektedir. Defter 16x45 ebadında, 24 sayfa ciltli ve ebrusuz şekilde düzenlenmiş olup adı geçen geri hizmet birliklerinin 23 Zi'l-hicce 1096 ile gurre-i Rebiü'l-evvel 1097 tarihleri arasında tutulmuş kayıtlarını içermektedir. Bu defterdeki bilgiler sadece Engürüs Seferi hazırlıklarını içerse de Osmanlı Devleti’nin sefer organizasyonu hakkında bazı ipuçları vermektedir.

Osmanlı sefer organizasyonunda muharip kuvvetlerin yanı sıra orduya yardım eden yardımc1 birlikler de her zaman mevcut olmuştu. Bur birlikler, savaş dönemlerinde ordunun ulaşım,

12 Özcan, “İbrahim Paşa, Melek", s. 337.

13 Silahdâr Mehmed Ağa, Silâhdâr Târîhi, II, s. 215-216; Râşid Mehmed, age., s. 480-481; Sami, age.,s. $560-561$.

14 Defterdar Sarı Mehmed Paşa, age., s. 199-200.

15 Kantemir, age., s. 82.

16 Râşid Mehmed, age., s. 484-485; Sami, age., s. 556.

17 Silahdâr Mehmed Ağa, Silâhdâr Târihi, II, s. 209-211.

18 Mustafa Nuri Paşa, age., s. 286; Râşid Mehmed, age., s. 486; Silahdâr Mehmed Ağa Silâhdâr Târîhi, II, s. 228-229; Parmaksızoğlu, agm., s.907; Özcan,” İbrahim Paşa”, s. 330. 
beslenme, silah ve teçhizat ikmali ${ }^{19}$, köprü yapımi ${ }^{20}$, yolların temizlenmesi, geçitlerin muhafaza edilmesi gibi önemli görevleri yerine getirmişlerdi. En az savaşan sınıf kadar önemli olan ve seferin başarısına katkıda bulunan bu yardımcı birliklerin yapmış oldukları işin ağırlığı, tehlike arz etmesi, ustalık ve teknik bilgi gerektirmesi istenilen işin zamanında hazırlanmasını zorlaştırmaktayd ${ }^{21}$. Ancak bu birliklerin görevlerini başarılı bir şekilde yerine getirmesi savaşın sonucunu direk etkilemekteydi.

Osmanlı Devleti 1685 Macaristan seferine çıkmadan önce savaş hazırlıkları kapsamında daha önceden belirlenmiş menzillere zahire nakli, yol ve köprü yapımı, sınırlardaki asker sayılarının artırılması, kalelerin tahkimi, orducu esnafının tedariki, yardımcı birliklerin hazırlanması ve donanmadaki eksikliklerin giderilmesi gibi konularda gerekli hazırlıkların yapılmasını sağlamıştır ${ }^{22}$.

1685 Macaristan seferi esnasında orduda muharip güçlerin yanı sıra yardımcı kuvvetlerin de var olduğunu çalışmaya konu olan defter kayıtlarından öğrenmekteyiz. Osmanlı askeri sistem içerisinde önemli rol oynayan geri hizmet birlikleri kalelerin savunulmasında ciddi görevler üstlenmişlerdir. 1685 Macaristan seferine İbrahim Paşa'nın mahiyyetinde katılacak olan Lağımcı, Beldar ve Neccar isimleri, alındıkları kazalara göre ayrı ayrı kayıt altına alınmıştır. Bu defter yapılan askeri hazırlıkların bir kısmı hakkında bize bazı bilgiler sunmaktadır.

Geri hizmet birliklerinden olan lağımcılar, teknik bir sınıf olup, toprak altından tüneller açar ve buralara yerleştirdikleri patlayıcı maddelerle, kale fetihlerini kolaylaştırırlardı. Ayrıca ordunun ağırlıklarıyla geçirilmesi için yeni köprü yapmak veya mevcut olanları tamir etmek, düşman tarafından lâgımları körletmek vazifesiyle de mükelleftiler. Lağımcılar, yaya kapıkulu askerlerinden olup iki kısma ayrılırlardı. Bir kısmı cebeci başının emri altında olup maaş alır, diğer kısmı ise zeamet ve tımar tasarruf ederlerdii23. Tımarlı lağımcıların başındaki amire $L a$ -

19 Mehmet İnbaşı, Ukrayna'da Osmanlılar Kamaniçe Seferi ve Sefer Organizasyonu (1672), Yeditepe Yayınları, İstanbul 2004, s. 121.

20 Tahir Sevinç, 1695 ve 1696 Avusturya Seferlerinde Organizasyon ve Lojistik, Marmara Üniversitesi Sosyal Bilimler Enstitüsü Türkiyat Araştırmaları Enstitüsü Türk Tarihi Anabilim Dalı Yeniçă̆ Tarihi Anabilim Dalı, Yayımlanmamış Doktora Tezi, İstanbul 2010, s. 134

21 Meryem Kaçan Erdoğan, II. Viyana Kuşatması, Marmara Üniversitesi Sosyal Bilimler Enstitüsü Türkiyat Araştırmaları Enstitüsü Türk Tarihi Anabilim Dalı Yeniçağ Tarihi Anabilim Dalı, Yayımlanmamış Doktora Tezi, İstanbul 2001, s. 27

22 Defterdar Sarı Mehmed Paşa, age., s. 194-203.

23 İnbaş1, age., s.116,124; Midhat Sertoğlu, Osmanlı Tarih Lûgatı, Enderun Kitabevi, İstanbul 1986, s. 198; Abdülkadir Özcan, “Osmanlı Askeri Teşkilatı”, Osmanlı VI, (Ed. Güler Eren), Yeni Türkiye Yayınları, Ankara 1999, s. 552; M. Zeki Pakalın, Osmanlı Tarih Değimleri ve Terimleri Sözlüğü, II, Milli Eğitim Basımevi, İstanbul 1983, s. 347-352; Ayrıca kale kuşatmaları esnasında lağımların nasıl açıldığı ve lağım saldırının nasıl gerçekleştirildiği konusunda detaylı bilgi için bk. Veysel Göger, 16. Yüzyıl Kale Kuşatmaları (Stratejik, Taktik, Kuşatma Aşamaları ve Teknolojisi), Marmara Üniversitesi Sosyal Bilimler Enstitüsü Türkiyat Araştırmaları Enstitüsü Türk Tarihi Anabilim Dalı Yeniçağ Tarihi Anabilim Dalı, Yayımlanmamış Doktora Tezi, İstanbul 2014, s. 118. 
ğımcıbaşı denirdi. Bundan başka kethüda ve çavuş, ocağın büyük zabitlerinden olup alemdar da küçük zabitlerdendi² ${ }^{24}$ Osmanlı Devleti, seferlerde gerektiğinde veya lağımcıların sayısı yetersiz olduğunda dışardan lağımcı alırdı. Bu lağımcılara belirli bir ücret ödenirdi. Ücretli lağımcıların paraları bulundukları bölgelerin haslarından, mukataa ve nüzül bedellerinden ya da şehirlerin mali bütçelerinden ödenirdi ${ }^{25}$.

Hendese bilmeyi gerektiren lağımcılık teşkilatı en mükemmel şeklini XVI. yüzyılda almıştır. Lağımcılar son büyük hünerlerini uzun süren Kandiye kuşatmasında göstermişler ve Girit' in tamamen fethinde büyük rol oynamışlardı. Buradaki Türk istihkam tekniği Fransız Generali Vauban tarafından öğrenilmiş ve zamanla Avrupa'ya yayılmıştır. Girit'in fethinden sona ihmal edilen teşkilat bozulmaya yüz tutmuş, III. Selim döneminde ise Humbaracı Ocağına bağlanmıştır. II. Mahmud zamanında Asâkir-i Mansûre-i Muhammediyye kurulurken Rumeli ve Anadolu'daki lağımcılar, İstanbul'a getirtilerek yoklamadan geçirilmiş ve sipahilik ünvanları kaldırılıp Tophâne-i Âmire Müşirliği’ne bağlanmışlardı. Bu teşkilat zamanla yerini modern istihkam sınıflarına bırakmıştı ${ }^{26}$.

1685 Macaristan seferi sırasında kale kuşatmaları esnasında lağımcılardan geniş bir şekilde istifade edildiğini görmekteyiz. Bunun için Anadolu ve Rumeli'nin muhtelif yerlerinden lağımcılar tedarik edilmiştir. İstanbul'dan tedarik edilip Serdar-1 Ekrem İbrahim Paşa'nın maiyetine verilen lağımcıların toplam sayısı 200 idi. Lağımcılara verilen ücret ise 500 esedî kuruştu. Anadolu eyaletinde bulunan Niğde Kazası'ndan ise 30 nefer lağımcı temin edilmiş ve bunlara 1.500 esedî kuruş para verilmişti. Kayseri'deki Müslim-gayrimüslim mahalleleri ve köylerinden mübaşir Ahmed Ağa marifetiyle 81 nefer lağımcı temin edilmişti. Bunlar için ise 330 esedî guruş para verilmişti. Yine Üsküp Sancağı ve tabi kazalarından 85 lağımcı tedarik edilmişti. Temin edilen lağımcılar arasında ser-lağımcıyan, usta, ser-bölükbaşı gibi farklı statülerde görevliler yer almaktadır. Bu durum yardımcı birlikler içerisinde de bir iş dağılımının varlığını göstermektedir. Ayrıca temin edilen lağımcı isimleri kefilleriyle deftere kaydedilmiş ve meskûn oldukları yerler belirtilmiştir. Lağımcı seçiminde etnik ve dini kimliğin ayırt edici özellik olmaması dikkat çekmektedir.

1685 Macaristan seferi için 231 kişi İstanbul'dan, 81 kişi Kayseri'den ve 85 kişi Üsküp'ten olmak üzere toplam 379 kişi lağımcı alınmıştı. Bu lağımcılardan Kayseri’den alınanlar Müslim ve gayrimüslim mahalleleri ile tabi köylerden, Üsküp’ten alınanlar Üsküp, Krotava, Kalkandelen, Köprülü ve İvranya'dan temin edilmiş iken İstanbul'dan olanların nerelerden temin edildikleri hakkında herhangi bir açıklama yapılmamıştır.

Yardımcı askeri birlikler içerisinde önemli guruplardan biri de beldarlardır. Beldarlar, önemli 
yol ve geçitlerdeki derbentleri muhafaza eden kimselerdi. Bunlar iki grup idiler. Birinci grup civar ve köy halkından olup çeşitli muafiyetler karşılığında bu işi yaparken ikinci gurup ücret karşılığında bu hizmeti yerine getirirdi. Derbentçi ile belderan arasındaki fark da bu idi. Derbentçi görevini muafiyet karşılığ 1 , belderan ise ücret karşılığ1 yapard1 ${ }^{27}$. Beldarlar, ordunun hareketi sırasında yolları açıp düzeltme işiyle uğraşırlardı. Bunlar, muharebe esnasında ordunun geri hizmetlerinde kullanılırlardı. Beldarların aldıkları ücretler bulundukları bölgeye göre değişir ve o yerin vergi dağıtım defterine alınıp halktan toplanırd $1^{28}$.

1685 Macaristan seferinde istihdam edilmeleri için lağımcılarda olduğu gibi beldarlar da farklı yerlerden temin edilmişlerdi. Temin edilen beldarların seçiminde Müslüman olup olmadığına bakılmaması, Osmanlı askeri teşkilat içerisinde farklı etnik grup ve dinden kişilerin varlığına işaret etmektedir. Temin edilen beldarlar isimleri ve kefilleri ile deftere kaydedilmiş ve meskûn oldukları yerler belirtilmiştir. Bu sefer için toplanan beldarların \%40'ının Edirne ve bağlı nahiyelerinden temin edilmiş olması dikkat çekmektedir.

1685 Macaristan seferi için Edirne Kazası'ndan 80, Ada Nahiyesi’nden 6, Çöke Nahiyesi'nden 12, Leskofça Kazası'ndan 14, Samakov Kazası'ndan 40, Biga Kazası'ndan 13, Lapseki Kazası'ndan 7, Eynepazarı Kazası'ndan 12, Manastır Nahiyesi'nden 12, Üsküdar Nahiyesi'nden 10, Alacahisar Sancağı'ndan 5, Ürgüb Kazası'ndan 1, Biga Sancağı'ndan 60, Güvercinlik Kazası'ndan 3 ve Kal'a-yı Sultaniye Kazası'ndan 3 olmak üzere toplam 308 belderan temin edilmişti.

Defterde adı geçen diğer bir yardımcı birlik ise saray teşkilatında ehl-i hiref arasında zikr edilen neccarlardır. Neccar, dülger ve doğramacı yerine kullanılan bir tabirdir² ${ }^{29}$. Ehl-i hiref s1nıfından olan neccarlar bina inşası, köprü ve kale tamiri, şayka yapımı, sefer sırasında ordunun ağrılıklarıyla geçeceği köprü ve yolların düzenlenmesi ve hazır duruma getirilmesi gibi önemli görevleri ifa ederlerdi. Bu vazifelerin aksaması savaşın sonucuna doğrudan etki edeceğinden işlerin dikkatle yapılmasına özen gösterilirdi. 1685 Macaristan seferinde istihdam edilmek üzere İstanbul' dan 35 nefer neccar tedarik edilmişti. Bunlar isim ve unvanlarıyla birlikte deftere kaydedilmişlerdi. Ancak neccarlara ne kadar ücret verildiği konusunda defterde herhangi bir bilgi mevcut değildir. Yine bu sefer sırasında Estergon'un muhafazasında istihdam edilmek üzere İstanbul'dan 13 nefer neccar temin edilmiştir. Bunlara verilen ücret ise 65 esedî kuruştur. Estergon Seferi için temin edilen neccarlar, İbrahim Paşa’nın (Melek İbrahim) maiyetinde çalışmışlardı.

27 M. Zeki Pakalın, "Belderân”, Osmanlı Tarih Değimleri ve Terimleri Sözlüğü, I, Milli Eğitim Basımevi, İstanbul 1983, s. 202.

28 İnbaş1, age., s. 126; Sertoğlu, age., s. 45; Pakalın, Osmanlı Tarih Değimleri ve Terimleri Sözlüğü, I, s. 202.

29 Pakalın, Osmanlı Tarih Değimleri ve Terimleri Sözlüğü, II, s. 666; Pakalın, Osmanlı Tarih Değimleri ve Terimleri Sözlüğ̈̈, I, s. 485. 


\section{Transkripsyon:}

MAD. d. 07723

\section{[1]}

Ser-asker ve vezîr-i mükerrem İbrahim Paşa hazretleri ile Engürüs seferi içün İstanbul tarafindan ihrâc olunan lağımcılardan mezbûr lağımcının sefer-i mezbûrdea icrâ-yı hizmet eyledüğüne ordusu tarafından verilen edâ tezkeresi olmağla mahalline kayd olmağın şerh verildi.

Fî 23 Zi'l-hicce sene 1096

Neferan:

'An-cânib-i Kayseri 49

'An-cânib-i İstanbul 68

\section{[2]}

\section{Zehâ'ir}

İhrâc kerde-i lağımciyân ve neccâran 'an-cânib-i mezkûrîn berâ-y1 sefer vezîrim serdâr-1 ekrem İbrahim Paşa el-vâki' fî 1096

'An-cânib-i İstanbul

\begin{tabular}{|c|c|c|c|}
\hline \multicolumn{4}{|l|}{ Lağımcıyân } \\
\hline $\begin{array}{l}\text { Ba-kefâlet-Gülabi ser- } \\
\text { lağımcıyân Yusuf } \\
\text { Tezkire-dâde fî } 19 \\
\text { Safer sene } 1097 \\
\text { Guruş-1 esedi } 5\end{array}$ & $\begin{array}{l}\text { Ba-kefâlet-i Usta Yusuf } \\
\text { Yüzbaş1 } \\
\text { Tezkire-dâde fî } 22 \\
\text { Zi'l-hicce sene } 1096 \\
\text { Guruş-1 esedi } 5\end{array}$ & $\begin{array}{l}\text { Ba-kefâlet-i Usta } \\
\text { Mehmed Yüzbaş1 } \\
\text { Tezkire-dâde fî } 22 \\
\text { Zi'l-hicce sene } 1096 \\
\text { Guruş-1 esedi } 5\end{array}$ & $\begin{array}{l}\text { Ba-kefâlet-i Mehmed } \\
\text { Usta Bağdaki } \\
\text { Ser-bölük }\end{array}$ \\
\hline $\begin{array}{l}\text { Hancioğlu Uğurlu ser- } \\
\text { bölük } \\
\text { Tezkire-dâde fî } 22 \\
\text { Zi’l-hicce sene } 1096 \\
\text { Guruş-1 esedi } 5\end{array}$ & $\begin{array}{l}\text { Ba-kefâlet-i Gülabi } \\
\text { Mehmed Rahtodanlı } \\
\text { Ahmed } \\
\text { ser-bölük } \\
\text { Tezkire-dâde fî } 22 \text { Zi'l- } \\
\text { hicce sene } 1096 \\
\text { Guruş-1 esedi } 5\end{array}$ & $\begin{array}{l}\text { Ba-kefâlet-i Gülabi } \\
\text { Ahmed Behram Sivâslı } \\
\text { ser-bölük }\end{array}$ & $\begin{array}{l}\text { Ba-kefâlet-i Gülabi } \\
\text { Mardiros Ohannes } \\
\text { ser-bölük }\end{array}$ \\
\hline $\begin{array}{l}\text { Ba-kefâlet-i Gülabi } \\
\text { Nefgos Nakis } \\
\text { ser-bölük } \\
\text { Tezkire-dâde fî } 22 \\
\text { Zi'l-hicce sene } 1096 \\
\text { Guruş-1 esedi } 5 \\
\text { Kâime-dâde fi } 28 \\
\text { Rebî'ü'l-âhir sene } \\
1097\end{array}$ & $\begin{array}{l}\text { Ba-kefâlet-i Merim } \\
\text { Manik Efendi }\end{array}$ & $\begin{array}{l}\text { Ba-kefâlet-i Gülabi } \\
\text { Hüseyin Musa } \\
\text { ser-bölük } \\
\text { Tezkire-dâde fî } 22 \text { Zi'l- } \\
\text { hicce sene } 1096 \\
\text { Guruş-1 esedi } 5 \\
\text { Kâime-dâde fî } 28 \\
\text { Rebî'ü’l-âhir sene } \\
1097\end{array}$ & $\begin{array}{l}\text { Ba-kefâlet-i Gülabi } \\
\text { Menasin Ohannes } \\
\text { ser-bölük } \\
\text { Tezkire-dâde fî } 22 \text { Zi'l- } \\
\text { hicce sene } 1096 \\
\text { Guruş-1 esedi } 5\end{array}$ \\
\hline
\end{tabular}




\begin{tabular}{|l|l|l|l|}
\hline $\begin{array}{l}\text { Ba-kefâlet-i Gülabi } \\
\text { Şaban İsbendani }\end{array}$ & $\begin{array}{l}\text { Ba-kefâlet-i Gülabi } \\
\text { İvaz Karabed }\end{array}$ & $\begin{array}{l}\text { Ba-kefâlet-i Gülabi } \\
\text { Bekir Hasan } \\
\text { Tezkire-dâde fî 22 Zi'l- } \\
\text { hicce sene 1096 } \\
\text { Guruş-1 esedi 5 } \\
\text { Kâime-dâde fî 28 } \\
\text { Rebî'ü'l-âhir1097 }\end{array}$ & $\begin{array}{l}\text { Ba-kefâlet-i Gülabi } \\
\text { Armena Haçok }\end{array}$ \\
\hline $\begin{array}{l}\text { Ba-kefâlet-i Gülabi } \\
\text { Orhan Bedros }\end{array}$ & $\begin{array}{l}\text { Ba-kefâlet-i Gülabi } \\
\text { İbrahim Sefer }\end{array}$ & $\begin{array}{l}\text { Ba-kefâlet-i Gülabi } \\
\text { Ahmed Abdullah }\end{array}$ & $\begin{array}{l}\text { Ba-kefâlet-i Gülabi } \\
\text { Sagır Mehmed Ağa } \\
\text { Mehmed Nasuh } \\
\text { Tezkire-dâde fî 22 Zi'l- } \\
\text { hicce sene 1096 } \\
\text { Guruş-1 esedi 5 }\end{array}$ \\
\hline $\begin{array}{l}\text { Ba-kefâlet-i } \\
\text { Sagır Mehmed Ağa } \\
\text { Mustafa Mehmed } \\
\text { Tezkire-dâde fî m. } \\
\text { Guruş-1 esedi 5 }\end{array}$ & $\begin{array}{l}\text { Ba-kefâlet-i } \\
\text { Sagır Mehmed Ağa } \\
\text { Mehmed Ali }\end{array}$ & $\begin{array}{l}\text { Ba-kefâlet-i Haçador } \\
\text { İbrahim Abdullah } \\
\text { Tenater Kogas } \\
\begin{array}{l}\text { Tezkire-dâde fî̀ 22 Zi’l- } \\
\text { hicce sene 1096 } \\
\text { Guruş-1 esedi 5 }\end{array}\end{array}$ & $\begin{array}{l}\text { Ba-kefâlet-i Yusuf } \\
\text { Kebür Sefer } \\
\text { Tezkire-dâde fî 22 Zi'l- } \\
\text { hicce sene 1096 } \\
\text { Guruş-1 esedi 5 }\end{array}$ \\
\hline
\end{tabular}

[3]

\begin{tabular}{|c|c|c|c|}
\hline $\begin{array}{l}\text { Ba-kefâlet-i Yusuf } \\
\text { Ali İskender } \\
\text { Tezkire-dâde fî m. } \\
\text { Guruş-1 esedi5 }\end{array}$ & $\begin{array}{l}\text { Ba-kefâlet-i Yusuf } \\
\text { Usta Bağvand Karabed } \\
\text { Tezkire-dâde fî } 19 \\
\text { Safer sene } 1097 \\
\text { Kâime-i dâde } 28 \\
\text { Rebî'ü'l-âhir sene } \\
1097\end{array}$ & $\begin{array}{l}\text { Ba-kefâlet-i Yusuf } \\
\text { Boris Uka }\end{array}$ & $\begin{array}{l}\text { Ba-kefâlet-i Yusuf } \\
\text { Paka Mikail } \\
\text { Tezkire-dâde fî } 22 \text { Zi’l- } \\
\text { hicce sene } 1096 \\
\text { Guruş-1 esedi } 5\end{array}$ \\
\hline $\begin{array}{l}\text { Ba-kefâlet-i Yusuf } \\
\text { Cerrah Karaca } \\
\text { Tezkire-dâde fî } 22 \text { Zi'l- } \\
\text { hicce sene } 1096 \\
\text { Kâime-i dâde fî } 28 \\
\text { Rebî'ü'l-âhir sene } \\
1097\end{array}$ & $\begin{array}{l}\text { Ba-kefâlet-i Yusuf } \\
\text { Bog[h] }] \text { os Musa } \\
\text { Guruş-1 esedi } 5\end{array}$ & $\begin{array}{l}\text { Ba-kefâlet-i Yusuf } \\
\text { Mehmed İsmail } \\
\text { Tezkire-dâde fî } 22 \text { Zi’l- } \\
\text { hicce sene } 1096 \\
\text { Guruş-1 esedi } 5\end{array}$ & $\begin{array}{l}\text { Ba-kefâlet-i Yusuf } \\
\text { Musa Mustafa } \\
\text { Tezkire-dâde fî } 22 \text { Zi’l- } \\
\text { hicce sene } 1096 \\
\text { Guruş-1 esedi } 5\end{array}$ \\
\hline $\begin{array}{l}\text { Ba-kefâlet-i Yusuf } \\
\text { Hidır Hoves }\end{array}$ & $\begin{array}{l}\text { Ba-kefâlet-i Yusuf } \\
\text { Ali Bektaş } \\
\text { Tezkire-dâde fî̀ m. } \\
\text { Guruş-1 esedi } 5\end{array}$ & $\begin{array}{l}\text { Ba-kefâlet-i Yusuf } \\
\text { Mehmed Bektaş } \\
\text { Tezkire-dâde fî m. } \\
\text { Guruş-1 esedi } 5\end{array}$ & $\begin{array}{l}\text { Ba-kefâlet-i Yusuf } \\
\text { Usta Yevan }\end{array}$ \\
\hline
\end{tabular}




\begin{tabular}{|c|c|c|c|}
\hline $\begin{array}{l}\text { Ba-kefâlet-i } \\
\text { Tavukçuoğlu } \\
\text { Küçük Aryan } \\
\text { Tezkire-dâde fî } 22 \text { Zi’l- } \\
\text { hicce sene } 1096 \\
\text { Guruş-1 esedi } 5\end{array}$ & $\begin{array}{l}\text { Ba-kefâlet-i } \\
\text { Kerhur } \\
\text { Hürmüz Karabed }\end{array}$ & $\begin{array}{l}\text { Ba-kefâlet-i } \\
\text { Ser-bölük Ahmed } \\
\text { Mustafa Siyam } \\
\text { Tezkire-dâde fî } 22 \text { Zi’l- } \\
\text { hicce sene } 1096 \\
\text { Guruş-1 esedi } 5\end{array}$ & $\begin{array}{l}\text { Ba-kefâlet-i } \\
\text { Yusuf Mikail } \\
\text { AliAbdullah } \\
\text { Tezkire-dâde fî } 6 \text { Safer } \\
\text { sene } 1097 \\
\text { Guruş-1 esedi } 5\end{array}$ \\
\hline $\begin{array}{l}\text { Ba-kefâlet-i } \\
\text { Alyon } \\
\text { Pavli Agina }\end{array}$ & $\begin{array}{l}\text { Ba-kefâlet-i } \\
\text { Cemal } \\
\text { Mehmed Semani } \\
\text { Tezkire-dâde fî } 22 \text { Zi'l- } \\
\text { hicce sene } 1096 \\
\text { Guruş-1 esedi } 5\end{array}$ & $\begin{array}{l}\text { Ba-kefâlet-i } \\
\text { Emir Hoca } \\
\text { Mustafa Süleyman } \\
\text { Tezkire-dâde fî } 22 \text { Zi'l- } \\
\text { hicce sene } 1096 \\
\text { Guruş-1 esedi } 5\end{array}$ & $\begin{array}{l}\text { Ba-kefâlet-i } \\
\text { Seyyid Hasan } \\
\text { Mehmed Osman } \\
\text { Tezkire-dâde fî } 22 \text { Zi'l- } \\
\text { hicce sene } 1096 \\
\text { Guruş-1 esedi } 5 \\
\text { Kâime-dâde fî } 28 \\
\text { Rebî'ü'l-âhir sene } \\
1097\end{array}$ \\
\hline $\begin{array}{l}\text { Ba-kefâlet-i } \\
\text { Abdullah Bahçevan } \\
\text {... Karaca }\end{array}$ & $\begin{array}{l}\text { Ba-kefâlet-i Gülabi } \\
\text { Ahmed Ramazan } \\
\text { Tezkire-dâde fî } 22 \text { Zi'l- } \\
\text { hicce sene } 1096 \\
\text { Guruş-1 esedi } 5 \\
\text { Kâime-dâde fî } 28 \\
\text { Rebî'ü'l-âhir sene1097 }\end{array}$ & $\begin{array}{l}\text { Ba-kefâlet-i } \\
\text { Samancı } \\
\text { Ridvan Ali } \\
\text { Tezkire-dâde fî } 22 \text { Zi'l- } \\
\text { hicce sene } 1096 \\
\text { Guruş-1 esedi } 5\end{array}$ & $\begin{array}{l}\text { Ba-kefâlet-i } \\
\text { Serkiz } \\
\text { İvaz Sefer }\end{array}$ \\
\hline $\begin{array}{l}\text { Ba-kefâlet-i } \\
\text { Samancı Bekir } \\
\text { Sefer Murad } \\
\text { Tezkire-dâde fî } 22 \text { Zi’l- } \\
\text { hicce sene } 1096 \\
\text { Guruş-1 esedi } 5\end{array}$ & $\begin{array}{l}\text { Ba-kefâlet-i } \\
\text { Samancı Bekir } \\
\text { Mehmed İbrahim } \\
\text { Tezkire-dâde fî } 22 \text { Zi’l- } \\
\text { hicce sene } 1096 \\
\text { Guruş-1 esedi } 5\end{array}$ & $\begin{array}{l}\text { Ba-kefâlet-i Bayram } \\
\text { Kasber Baram }\end{array}$ & $\begin{array}{l}\text { Ba-kefâlet-i } \\
\text { Secad Hüseyin } \\
\text { Karad Marak }\end{array}$ \\
\hline $\begin{array}{l}\text { Ba-kefâlet-i } \\
\text { Taşcı Sultan } \\
\text { Melkon Asadur }\end{array}$ & $\begin{array}{l}\text { Ba-kefâlet-i } \\
\text { Taşcı Sultan } \\
\text { Artin Sultan }\end{array}$ & $\begin{array}{l}\text { Ba-kefâlet-i } \\
\text { Merim Kari } \\
\text { Mikail Emin }\end{array}$ & $\begin{array}{l}\text { Ba-kefâlet-i Merim } \\
\text { Karabed Murad } \\
\text { Tezkire-dâde fî } 22 \text { Zi'l- } \\
\text { hicce sene } 1096 \\
\text { Guruş-1 esedi } 5 \\
\text { Kâime-dâde fî } 28 \\
\text { Rebî'’u’'l-âhir sene } \\
1097\end{array}$ \\
\hline $\begin{array}{l}\text { Ba-kefâlet-i Merim } \\
\text { İvaz Oğannes } \\
\text { Tezkire-dâde fî } 22 \text { Zi’l- } \\
\text { hicce sene } 1096 \\
\text { Guruş-1 esedi } 5\end{array}$ & $\begin{array}{l}\text { Ba-kefâlet-i Merim } \\
\text { Osman Ali }\end{array}$ & $\begin{array}{l}\text { Ba-kefâlet-i Merim } \\
\text { Mehmed Osman }\end{array}$ & $\begin{array}{l}\text { Ba-kefâlet-i Merim } \\
\text { Boğoz Radik } \\
\text { Tezkire-dâde fî } 22 \text { Zi'l- } \\
\text { hicce sene } 1096 \\
\text { Guruş-1 esedi } 5\end{array}$ \\
\hline
\end{tabular}


[4]

\begin{tabular}{|c|c|c|c|}
\hline $\begin{array}{l}\text { Ba-kefâlet-i Merim } \\
\text { Bandırmalı Uğur }\end{array}$ & $\begin{array}{l}\text { Ba-kefâlet-i Norsez } \\
\text { Mehmed İbrahim } \\
\text { Tezkire-dâde fî } 22 \text { Zi’1- } \\
\text { hicce sene } 1096 \\
\text { Guruş-1 esedi } 5\end{array}$ & $\begin{array}{l}\text { Ba-kefâlet-i Norsez } \\
\text { Armena Bedros }\end{array}$ & $\begin{array}{l}\text { Ba-kefâlet-i Perdah(t) } \\
\text { çı Ahmed } \\
\text { Ahmed İsmail } \\
\text { Tezkire-dâde fî } 22 \text { Zi’l- } \\
\text { hicce sene } 1096 \\
\text { Guruş-1 esedi } 5\end{array}$ \\
\hline $\begin{array}{l}\text { Ba-kefâlet-i Kogas } \\
\text { Haçador Kogas }\end{array}$ & $\begin{array}{l}\text { Ba-kefâlet-i Gülabi } \\
\text { Sinan Abdi Bey }\end{array}$ & $\begin{array}{l}\text { Ba-kefâlet-i Mehmed } \\
\text { Salim } \\
\text { Kasbad Artin }\end{array}$ & $\begin{array}{l}\text { Ba-kefâlet-i Bedros } \\
\text { Kalfa } \\
\text { Poli Kostantin } \\
\text { Tezkire-dâde fî } 22 \text { Zi’l- } \\
\text { hicce sene } 1096 \\
\text { Guruş-1 esedi } 5\end{array}$ \\
\hline $\begin{array}{l}\text { Ba-kefâlet-i Ferman(i) } \\
\text { Uzun } \\
\text { Ahmed Abdullah } \\
\text { Tezkire-dâde fî } 22 \text { Zi'l- } \\
\text { hicce sene } 1096 \\
\text { Guruş-1 esedi } 5\end{array}$ & $\begin{array}{l}\text { Ba-kefâlet-i } \\
\text { Tavukçuoğlu } \\
\text { Bog(h)os Nakim }\end{array}$ & $\begin{array}{l}\text { Ba-kefâlet-i Kapukıran } \\
\text { Yanos Murad }\end{array}$ & $\begin{array}{l}\text { Ba-kefâlet-i Kapukıran } \\
\text { Şahin Sefer } \\
\text { Tezkire-dâde fî } 22 \text { Zi'l- } \\
\text { hicce sene } 1096 \\
\text { Guruş-1 esedi } 5 \\
\text { Kâime-dâde fî̀ } 28 \\
\text { Rebî'ü'l-âhir sene } \\
1097\end{array}$ \\
\hline $\begin{array}{l}\text { Ba-kefâlet-i Kapukıran } \\
\text { Manuk Panos } \\
\text { Tezkire-dâde fî } 22 \text { Zi’1- } \\
\text { hicce sene } 1096 \\
\text { Guruş-1 esedi } 5\end{array}$ & $\begin{array}{l}\text { Ba-kefâlet-i Oğanes } \\
\text { Bağvand Markar }\end{array}$ & $\begin{array}{l}\text { Ba-kefâlet-i ser-bölük } \\
\text { Ahmed } \\
\text { Musa Bayezid } \\
\text { Tezkire-dâde fî } 22 \text { Zi’l- } \\
\text { hicce sene } 1096 \\
\text { Guruş-1 esedi } 5\end{array}$ & $\begin{array}{l}\text { Ba-kefâlet-i Ferman(i) } \\
\text { Uzun } \\
\text { Ali Himmet } \\
\text { Tezkire-dâde fî } 22 \text { Zi’1- } \\
\text { hicce sene } 1096 \\
\text { Guruş-1 esedi } 5\end{array}$ \\
\hline $\begin{array}{l}\text { Ba-kefâlet-i } \\
\text { Manukoğlu } \\
\text { Yosef Agob }\end{array}$ & $\begin{array}{l}\text { Ba-kefâlet-i Murad } \\
\text { Haçador Serkiz }\end{array}$ & $\begin{array}{l}\text { Ba-kefâlet-i Yağcı } \\
\text { Yami Marhad } \\
\text { Kirkor Markar } \\
\text { Tezkire-dâde fî } 22 \text { Zi'l- } \\
\text { hicce sene } 1096 \\
\text { Guruş-1 esedi } 5\end{array}$ & $\begin{array}{l}\text { Ba-kefâlet-i Tomad } \\
\text { Şahin Murad }\end{array}$ \\
\hline $\begin{array}{l}\text { Ba-kefâlet-i Gülabi } \\
\text { Ohannes Haçador }\end{array}$ & $\begin{array}{l}\text { Ba-kefâlet-i } \\
\text { Uylukçuoğlu } \\
\text { Norsez Serkiz } \\
\text { Tezkire-dâde fî } 22 \text { Zi’1- } \\
\text { hicce sene } 1096 \\
\text { Guruş-1 esedi } 5\end{array}$ & $\begin{array}{l}\text { Ba-kefâlet-i Bağvand } \\
\text { Anuk Emirdeva }\end{array}$ & $\begin{array}{l}\text { Ba-kefâlet-i Ohannes } \\
\text { Aleksan Vartmon }\end{array}$ \\
\hline
\end{tabular}




\begin{tabular}{|c|c|c|c|}
\hline $\begin{array}{l}\text { Ba-kefâlet-i Allahverdi } \\
\text { İvaz Abdullah } \\
\text { Tezkire-dâde fî } 22 \text { Zi'l- } \\
\text { hicce sene } 1096 \\
\text { Guruş-1 esedi } 5 \\
\text { Kâime-dâde fî } 28 \\
\text { Rebî'ü'l-âhir sene1097 }\end{array}$ & $\begin{array}{l}\text { Ba-kefâlet-i Mardiros } \\
\text { Kalfa } \\
\text { Emir Demiri }\end{array}$ & $\begin{array}{l}\text { Ba-kefâlet-i Hüseyin } \\
\text { Serkiz Arekin }\end{array}$ & $\begin{array}{l}\text { Ba-kefâlet-i Mabtot } \\
\text { Yani Kosta }\end{array}$ \\
\hline $\begin{array}{l}\text { Ba-kefâlet-i } \\
\text { Uylukçuoğlu } \\
\text { Sahak Mikail }\end{array}$ & $\begin{array}{l}\text { Ba-kefâlet-i Kassâb } \\
\text { Hüseyin } \\
\text { İvaz Kosti }\end{array}$ & $\begin{array}{l}\text { Ba-kefâlet-i Haçador } \\
\text { Davud Serkiz }\end{array}$ & $\begin{array}{l}\text { Ba-kefâlet-i Horasanc1 } \\
\text { Serkiz Manuk } \\
\text { Tezkire-dâde fî } 22 \text { Zi'l- } \\
\text { hicce sene } 1096 \\
\text { Guruş-1 esedi } 5 \\
\text { Kâime-dâde fî } 28 \\
\text { Rebî'ử'l-âhir sene1097 }\end{array}$ \\
\hline $\begin{array}{l}\text { Ba-kefâlet-i Gülabi } \\
\text { Uka Bornik }\end{array}$ & $\begin{array}{l}\text { Ba-kefâlet-i Ohannes } \\
\text { Kirkor Haçi(o)k } \\
\text { Tezkire-dâde fî } 22 \text { Zi’1- } \\
\text { hicce sene } 1096 \\
\text { Guruş-1 esedi } 5\end{array}$ & $\begin{array}{l}\text { Ba-kefâlet-i Vartan } \\
\text { Haçik Vartan } \\
\text { Tezkire-dâde fî } 22 \text { Zi'l- } \\
\text { hicce sene } 1096 \\
\text { Guruş-1 esedi } 5 \\
\text { Kâime-dâde fî } 28 \\
\text { Rebî'ü'l-âhir sene } \\
1097\end{array}$ & $\begin{array}{l}\text { Ba-kefâlet-i İskender } \\
\text { Ukakin Kirkor } \\
\text { Tezkire-dâde fî } 22 \text { Zi'l- } \\
\text { hicce sene } 1096 \\
\text { Guruş-1 esedi } 5\end{array}$ \\
\hline
\end{tabular}

[5]

\begin{tabular}{|c|c|c|c|}
\hline $\begin{array}{l}\text { Ba-kefâlet-i İskender } \\
\text { Osman Abdullah }\end{array}$ & $\begin{array}{l}\text { Ba-kefâlet-i Kiryako } \\
\text { Drako Petro }\end{array}$ & $\begin{array}{l}\text { Ba-kefâlet-i Bağçıvan } \\
\text { Mardiros Giragos } \\
\text { Tezkire-dâde fî } 22 \text { Zi'l- } \\
\text { hicce sene } 1096 \\
\text { Guruş-1 esedi } 5\end{array}$ & $\begin{array}{l}\text { Ba-kefâlet-i Bedros } \\
\text { Aleksan Murad } \\
\text { Tezkire-dâde fî } 22 \text { Zi'l- } \\
\text { hicce sene } 1096 \\
\text { Guruş-1 esedi } 5\end{array}$ \\
\hline $\begin{array}{l}\text { Ba-kefâlet-i Artin } \\
\text { Veli Ali } \\
\text { Tezkire-dâde fî } 22 \text { Zi’1- } \\
\text { hicce sene } 1096 \\
\text { Guruş-1 esedi } 5\end{array}$ & $\begin{array}{l}\text { Ba-kefâlet-i Artin } \\
\text { Mehmed Pir Veli } \\
\text { Tezkire-dâde fî } 22 \text { Zi'l- } \\
\text { hicce sene } 1096 \\
\text { Guruş-1 esedi } 5\end{array}$ & $\begin{array}{l}\text { Ba-kefâlet-i Bedros } \\
\text { İvaz ve Mehmed Sefer } \\
\text { Tezkire-dâde fî } 22 \text { Zi'l- } \\
\text { hicce sene } 1096 \\
\text { Guruş-1 esedi } 5 \\
\text { Kâime-dâde fi } 28 \\
\text { Rebî'ü'l-âhir sene } \\
1097\end{array}$ & $\begin{array}{l}\text { Ba-kefâlet-i Budak } \\
\text { İbrahim Ali } \\
\text { Tezkire-dâde fî } 22 \text { Zi'l- } \\
\text { hicce sene } 1096 \\
\text { Guruş-1 esedi } 5 \\
\text { Kâime-dâde fi } 28 \\
\text { Rebî̀'ü'l-âhir sene1097 }\end{array}$ \\
\hline $\begin{array}{l}\text { Ba-kefâlet-i Ahmed } \\
\text { Mehmed Abdullah } \\
\text { Tezkire-dâde fî } 22 \text { Zi'l- } \\
\text { hicce sene } 1096 \\
\text { Guruş-1 esedi } 5\end{array}$ & $\begin{array}{l}\text { Ba-kefâlet-i } \\
\text { Tavukçuoğlu } \\
\text { Bedros Boris }\end{array}$ & $\begin{array}{l}\text { Ba-kefâlet-i } \\
\text { Tavukçuoğlu } \\
\text { İvaz Kurd }\end{array}$ & $\begin{array}{l}\text { Ba-kefâlet-i Bedros } \\
\text { Kalfa } \\
\text { Receb Abdullah } \\
\text { Tezkire-dâde fî } 22 \text { Zi'1- } \\
\text { hicce sene } 1096 \\
\text { Guruş-1 esedi } 5\end{array}$ \\
\hline
\end{tabular}




\begin{tabular}{|c|c|c|c|}
\hline $\begin{array}{l}\text { Ba-kefâlet-i ser-bölük } \\
\text { Markar } \\
\text { Mehmed Kürdoğlu } \\
\text { Tezkire-dâde fî } 22 \text { Zi'l- } \\
\text { hicce sene } 1096 \\
\text { Guruş-1 esedi } 5\end{array}$ & $\begin{array}{l}\text { Ba-kefâlet-i İbrahim } \\
\text { Hristo Vasil }\end{array}$ & $\begin{array}{l}\text { Ba-kefâlet-i Mehmed } \\
\text { Mehmed Veli } \\
\text { Tezkire-dâde fî } 22 \text { Zi’l- } \\
\text { hicce sene } 1096 \\
\text { Guruş-1 esedi } 5\end{array}$ & $\begin{array}{l}\text { Ba-kefâlet-i Ahmed } \\
\text { Serkiz Gragor }\end{array}$ \\
\hline $\begin{array}{l}\text { Ba-kefâlet-i Hüseyin } \\
\text { Malkoç Dursun }\end{array}$ & $\begin{array}{l}\text { Ba-kefâlet-i Bedros } \\
\text { Halife } \\
\text { Sefer Kostonter }\end{array}$ & $\begin{array}{l}\text { Ba-kefâlet-i Bağvand } \\
\text { Agob Davud }\end{array}$ & $\begin{array}{l}\text { Ba-kefâlet-i Matos } \\
\text { Toros } \\
\text { Dursun Hankik } \\
\text { Tezkire-dâde fî } 22 \text { Zi'l- } \\
\text { hicce sene } 1096 \\
\text { Guruş-1 esedi } 5 \\
\text { Kâime-dâde fi } 28 \\
\text { Rebî'ü'l-âhir sene } \\
1097\end{array}$ \\
\hline $\begin{array}{l}\text { Ba-kefâlet-i Matos } \\
\text { Serkiz Hankik } \\
\text { Tezkire-dâde fî } 22 \text { Zi'l- } \\
\text { hicce sene } 1096 \\
\text { Guruş-1 esedi } 5 \\
\text { Kâime-dâde fi } 28 \\
\text { Rebî'ü'l-âhir sene } 1097\end{array}$ & $\begin{array}{l}\text { Ba-kefâlet-i Manos } \\
\text { Giregos Agil }\end{array}$ & $\begin{array}{l}\text { Ba-kefâlet-i Artin } \\
\text { İbrahim Hatem }\end{array}$ & $\begin{array}{l}\text { Ba-kefâlet-i Davud } \\
\text { Kalfa } \\
\text { Sahak Kirkor }\end{array}$ \\
\hline $\begin{array}{l}\text { Ba-kefâlet-i Yusuf } \\
\text { Yüzbaş1 } \\
\text { Karir Kirkor }\end{array}$ & $\begin{array}{l}\text { Ba-kefâlet-i Gülabi } \\
\text { İbrahim Kasbar }\end{array}$ & $\begin{array}{l}\text { Ba-kefâlet-i Gülabi } \\
\text { Serkiz Kirkor } \\
\text { Tezkire-dâde fî } 22 \text { Zi’1- } \\
\text { hicce sene } 1096 \\
\text { Guruş-1 esedi } 5\end{array}$ & $\begin{array}{l}\text { Ba-kefâlet-i Artin } \\
\text { Ağyar } \\
\text { İhtiyar Serkiz Tezkire- } \\
\text { dâde fî } 22 \text { Zi'l-hicce } \\
\text { sene } 1096 \\
\text { Guruş-1 esedi } 5 \\
\text { Kâime-dâde fi } 28 \\
\text { Rebî̀'u’'l-âhir sene1097 }\end{array}$ \\
\hline $\begin{array}{l}\text { Ba-kefâlet-i } \\
\text { Tavukçuoğlu } \\
\text { Mustafa Abdullah }\end{array}$ & $\begin{array}{l}\text { Ba-kefâlet-i İskender } \\
\text { Resul Musa Tezkire- } \\
\text { dâde fî } 22 \text { Zi'l-hicce } \\
\text { sene } 1096 \\
\text { Guruş-1 esedi } 5\end{array}$ & $\begin{array}{l}\text { Ba-kefâlet-i Yusuf } \\
\text { Mikail } \\
\text { Murad Kostonito } \\
\text { Tezkire-dâde fî } 22 \text { Zi'l- } \\
\text { hicce sene } 1096 \\
\text { Guruş-1 esedi } 5 \\
\text { Kâime-dâde fi } 28 \\
\text { Rebî'ü'l-âhir sene } \\
1097\end{array}$ & $\begin{array}{l}\text { Ba-kefâlet-i Artin } \\
\text { Sefer Boris } \\
\text { Tezkire-dâde fî } 22 \text { Zi'1- } \\
\text { hicce sene } 1096 \\
\text { Guruş-1 esedi } 5\end{array}$ \\
\hline $\begin{array}{l}\text { Ba-kefâlet-i Nikola } \\
\text { Ohan Kogas } \\
\text { Tezkire-dâde fî } 22 \text { Zi'l- } \\
\text { hicce sene } 1096 \\
\text { Guruş-1 esedi } 5\end{array}$ & $\begin{array}{l}\text { Ba-kefâlet-i Esfador } \\
\text { Kirkor Kostoster }\end{array}$ & $\begin{array}{l}\text { Ba-kefâlet-i Yusuf } \\
\text { Yüzbaş1 Abdurrahman } \\
\text { Ahmed } \\
\text { Tezkire-dâde fî } 22 \text { Zi’l- } \\
\text { hicce sene } 1096 \\
\text { Guruş-1 esedi } 5\end{array}$ & $\begin{array}{l}\text { Ba-kefâlet-i Yusuf } \\
\text { Yüzbaşı } \\
\text { Boğoz Haçik }\end{array}$ \\
\hline
\end{tabular}


[6]

\begin{tabular}{|c|c|c|c|}
\hline $\begin{array}{l}\text { Ba-kefâlet-i Yusuf } \\
\text { Yüzbaşı } \\
\text { Artin Kosdi }\end{array}$ & $\begin{array}{l}\text { Ba-kefâlet-i Yusuf } \\
\text { Yüzbaşı } \\
\text { Serkiz Nahik }\end{array}$ & $\begin{array}{l}\text { Ba-kefâlet-i Kirkor } \\
\text { AsadurSefer }\end{array}$ & $\begin{array}{l}\text { Ba-kefâlet-i Kirkor } \\
\text { Minas Kirkor }\end{array}$ \\
\hline $\begin{array}{l}\text { Ba-kefâlet-i Yusuf } \\
\text { Yanos Haçik }\end{array}$ & $\begin{array}{l}\text { Ba-kefâlet-i Yusuf } \\
\text { Lefter Ömer } \\
\text { Tezkire-dâde fî } 22 \text { Zi’1- } \\
\text { hicce sene } 1096 \\
\text { Guruş-1 esedi } 5\end{array}$ & $\begin{array}{l}\text { Ba-kefâlet-i Manuk } \\
\text { Amader Manuk } \\
\text { Tezkire-dâde fî } 22 \text { Zi’l- } \\
\text { hicce sene } 1096 \\
\text { Guruş-1 esedi } 5 \\
\end{array}$ & $\begin{array}{l}\text { Ba-kefâlet-i Üsküdarlı } \\
\text { Sefer Malkoç } \\
\text { Tezkire-dâde fî } 22 \text { Zi'l- } \\
\text { hicce sene } 1096 \\
\text { Guruş-1 esedi } 5\end{array}$ \\
\hline $\begin{array}{l}\text { Ba-kefâlet-i Artin } \\
\text { Sefer Murad }\end{array}$ & $\begin{array}{l}\text { Ba-kefâlet-i Mehmed } \\
\text { Ağa } \\
\text { Mahmud Mustafa } \\
\text { Tezkire-dâde fî } 22 \text { Zi'l- } \\
\text { hicce sene } 1096 \\
\text { Guruş-1 esedi } 5\end{array}$ & $\begin{array}{l}\text { Ba-kefâlet-i Şaban } \\
\text { Mehmed Nasib } \\
\text { Tezkire-dâde fî } 22 \text { Zi’l- } \\
\text { hicce sene } 1096 \\
\text { Guruş-1 esedi } 5\end{array}$ & $\begin{array}{l}\text { Ba-kefâlet-i Mehmed } \\
\text { Halife } \\
\text { Himmet Nasib } \\
\text { Tezkire-dâde fî } 22 \text { Zi'l- } \\
\text { hicce sene } 1096 \\
\text { Guruş-1 esedi } 5\end{array}$ \\
\hline $\begin{array}{l}\text { Ba-kefâlet-i Madikoğlu } \\
\text { Ahmed Abdullah } \\
\text { Tezkire-dâde fî } 22 \text { Zi'l- } \\
\text { hicce sene } 1096 \\
\text { Guruş-1 esedi } 5\end{array}$ & $\begin{array}{l}\text { Ba-kefâlet-i Bağdasar } \\
\text { Gaştaş Kostantin }\end{array}$ & $\begin{array}{l}\text { Ba-kefâlet-i Markar } \\
\text { Arslan Asadur }\end{array}$ & $\begin{array}{l}\text { Ba-kefâlet-i Gülabi } \\
\text { Hüsrev Yusuf } \\
\text { Tezkire-dâde fî } 22 \text { Zi'l- } \\
\text { hicce sene } 1096 \\
\text { Guruş-1 esedi } 5 \\
\text { Kâime-dâde fi } 28 \\
\text { Rebî'ü'l-âhir sene } \\
1097\end{array}$ \\
\hline $\begin{array}{l}\text { Ba-kefâlet-i el-Hac } \\
\text { Ahmed } \\
\text { Karabed Sefer } \\
\text { Tezkire-dâde fî } 22 \text { Zi'l- } \\
\text { hicce sene } 1096 \\
\text { Guruş-1 esedi } 5 \\
\end{array}$ & $\begin{array}{l}\text { Ba-kefâlet-i Ahmed } \\
\text { Ser-bölük } \\
\text { Hasan İbrahim }\end{array}$ & $\begin{array}{l}\text { Ba-kefâlet-i Yusuf } \\
\text { Mikail } \\
\text { Ahmedullah } \\
\text { Tezkire-dâde fî } 22 \text { Zi'l- } \\
\text { hicce sene } 1096 \\
\text { Guruş-1 esedi } 5\end{array}$ & $\begin{array}{l}\text { Ba-kefâlet-i Davud } \\
\text { Kalfa } \\
\text { Karamanlı Ohannes } \\
\text { Tezkire-dâde fî } 22 \text { Zi'l- } \\
\text { hicce sene } 1096 \\
\text { Guruş-1 esedi } 5\end{array}$ \\
\hline $\begin{array}{l}\text { Ba-kefâlet-i Davud } \\
\text { Kalfa } \\
\text { Mehmed Mustafa } \\
\text { Tezkire-dâde fî } 22 \text { Zi'l- } \\
\text { hicce sene } 1096 \\
\text { Guruş-1 esedi } 5\end{array}$ & $\begin{array}{l}\text { Ba-kefâlet-i Yusuf } \\
\text { Yüzbaş1 } \\
\text { Bali Karakoç Tezkire- } \\
\text { dâde fî } 22 \text { Zi'l-hicce } \\
\text { sene } 1096 \\
\text { Guruş-1 esedi } 5\end{array}$ & $\begin{array}{l}\text { Ba-kefâlet-i Yusuf } \\
\text { Mustafa Bilal } \\
\text { Tezkire-dâde fî̀ } 22 \text { Zi'l- } \\
\text { hicce sene } 1096 \\
\text { Guruş-1 esedi } 5\end{array}$ & $\begin{array}{l}\text { Ba-kefâlet-i Bedros } \\
\text { Kalfa } \\
\text { Armena Bedros } \\
\text { Tezkire-dâde fî } 22 \text { Zi'l- } \\
\text { hicce sene } 1096 \\
\text { Guruş-1 esedi } 5\end{array}$ \\
\hline $\begin{array}{l}\text { Ba-kefâlet-i Bedros } \\
\text { Arslan Sevan } \\
\text { Tezkire-dâde fî } 22 \text { Zi'l- } \\
\text { hicce sene } 1096 \\
\text { Guruş-1 esedi } 5\end{array}$ & $\begin{array}{l}\text { Ba-kefâlet-i } \\
\text { Tavukçuoğlu } \\
\text { Papazoğlu Mardiros }\end{array}$ & $\begin{array}{l}\text { Ba-kefâlet-i Haçador } \\
\text { Noder Sefer }\end{array}$ & $\begin{array}{l}\text { Ba-kefâlet-i } \\
\text { Otlukçuoğlu } \\
\text { Simavon Ohannes }\end{array}$ \\
\hline $\begin{array}{l}\text { Ba-kefâlet-i Yusuf } \\
\text { Makariç Atos }\end{array}$ & $\begin{array}{l}\text { Ba-kefâlet-i Yusuf } \\
\text { Mikail } \\
\text { Arslan Üzümcü }\end{array}$ & $\begin{array}{l}\text { Ba-kefâlet-i Gülabi } \\
\text { Mardiros Serkiz }\end{array}$ & $\begin{array}{l}\text { Ba-kefâlet-i Yusuf } \\
\text { Mikail } \\
\text { Artin Mikail }\end{array}$ \\
\hline
\end{tabular}




\begin{tabular}{|l|l|l||l|}
\hline Ba-kefâlet-i & Ba-kefâlet-i Markar & Ba-kefâlet-i Göncü & Ba-kefâlet-i Avdik \\
Tavukçuoğlu & ser-bölük & Mustafa & İvaz Abdullah \\
Bağdasar & Sinan Agob herbirinin & Ömer Nasib & Tezkire-dâde fî 22 Zi'l- \\
Agin & tezkiresi hak olarak & Tezkire-dâde fî 22 Zi'l- & hicce sene 1096 \\
& verilmiş & hicce sene 1096 & Guruş-1 esedi 5 \\
& Guruş-1 esedi 5 & Guruş-1 esedi 5 & \\
\hline
\end{tabular}

[7]

\begin{tabular}{|c|c|c|c|}
\hline $\begin{array}{l}\text { Ba-kefâlet-i Kiryako } \\
\text { Ömer Abdullah } \\
\text { Tezkire-dâde fî } 22 \text { Zi’l- } \\
\text { hicce sene } 1096 \\
\text { Guruş-1 esedi } 5\end{array}$ & $\begin{array}{l}\text { Ba-kefâlet-i Kiryako } \\
\text { Hasan Mehmed }\end{array}$ & $\begin{array}{l}\text { Ba-kefâlet-i } \\
\text { Tavukçuoğlu } \\
\text { Altıparmak Serkiz }\end{array}$ & $\begin{array}{l}\text { Ba-kefâlet-i Yusuf } \\
\text { Yüzbaş1 } \\
\text { Ömer Ali } \\
\text { Tezkire-dâde fî } 22 \text { Zi'l- } \\
\text { hicce sene } 1096 \\
\text { Guruş-1 esedi } 5\end{array}$ \\
\hline $\begin{array}{l}\text { Ba-kefâlet-i Gülabi } \\
\text { Agob Minas } \\
\text { Tezkire-dâde fî } 22 \text { Zi'l- } \\
\text { hicce sene } 1096 \\
\text { Guruş-1 esedi } 5\end{array}$ & $\begin{array}{l}\text { Ba-kefâlet-i Budak } \\
\text { Ali Emrullah }\end{array}$ & $\begin{array}{l}\text { Ba-kefâlet-i İbrahim } \\
\text { Sefer Kirkor }\end{array}$ & $\begin{array}{l}\text { Ba-kefâlet-i Markar } \\
\text { İsalı Markar } \\
\text { Tezkire-dâde fî } 22 \text { Zi'l- } \\
\text { hicce sene } 1096 \\
\text { Guruş-1 esedi } 5 \\
\text { Kâime-dâde fi } 28 \\
\text { Rebî'ü’l-âhir sene } \\
1097\end{array}$ \\
\hline $\begin{array}{l}\text { Ba-kefâlet-i Bağvand } \\
\text { Şahin Ağca }\end{array}$ & $\begin{array}{l}\text { Ba-kefâlet-i } \\
\text { Tavukçuoğlu } \\
\text { Ohannes Kurd }\end{array}$ & $\begin{array}{l}\text { Ba-kefâlet-i Zülfükar } \\
\text { Sefer Tavşan }\end{array}$ & $\begin{array}{l}\text { Ba-kefâlet-i Yusuf } \\
\text { Yüzbaş1 } \\
\text { Mehmed Abdullah } \\
\text { Tezkire-dâde fî } 22 \text { Zi'l- } \\
\text { hicce sene } 1096 \\
\text { Guruş-1 esedi } 5\end{array}$ \\
\hline $\begin{array}{l}\text { Ba-kefâlet-i Markar } \\
\text { Mustafa Abdullah } \\
\text { Tezkire-dâde fî } 22 \text { Zi'l- } \\
\text { hicce sene } 1096 \\
\text { Guruş-1 esedi } 5 \\
\text { Kâime-dâde fi } 28 \\
\text { Rebî'ü'l-âhir sene } \\
1097\end{array}$ & $\begin{array}{l}\text { Ba-kefâlet-i Yusuf } \\
\text { Yüzbaş1 } \\
\text { Hüseyin Ali } \\
\text { Tezkire-dâde fî } 22 \text { Zi'l- } \\
\text { hicce sene } 1096 \\
\text { Guruş-1 esedi } 5 \\
\text { Kâime-dâde fi } 28 \\
\text { Rebî'ü'l-âhir sene } \\
1097\end{array}$ & $\begin{array}{l}\text { Ba-kefâlet-i İsayi } \\
\text { Makrir Serkiz } \\
\text { Tezkire-dâde fî } 19 \\
\text { Safer sene } 1097 \\
\text { Guruş-1 esedi } 5 \\
\text { Kâime-dâde fi } 28 \\
\text { Rebî'ü'l-âhir sene } \\
1097\end{array}$ & $\begin{array}{l}\text { Ba-kefâlet-i Gülabi } \\
\text { İvaz Sefer } \\
\text { Tezkire-dâde fî } 22 \text { Zi'l- } \\
\text { hicce sene } 1096 \\
\text { Guruş-1 esedi } 5\end{array}$ \\
\hline $\begin{array}{l}\text { Ba-kefâlet-i Davud } \\
\text { Haçik Manuk }\end{array}$ & $\begin{array}{l}\text { Ba-kefâlet-i Giragos } \\
\text { Murad Sinan }\end{array}$ & $\begin{array}{l}\text { Ba-kefâlet-i Giragos } \\
\text { Bedros Kirkor }\end{array}$ & $\begin{array}{l}\text { Ba-kefâlet-i Deli } \\
\text { Bedros } \\
\text { Ahmed Abdullah }\end{array}$ \\
\hline
\end{tabular}




\begin{tabular}{|l||l|l|l|}
\hline $\begin{array}{l}\text { Ba-kefâlet-i Kapukıran } \\
\text { Ali Sinan }\end{array}$ & $\begin{array}{l}\text { Ba-kefâlet-i Ahmed } \\
\text { Beşe } \\
\text { Ibrahim Mehmed } \\
\text { Tezkire-dâde fî 12 } \\
\text { Safer sene 1097 } \\
\text { Guruş-1 esedi 5 } \\
\text { Der-kenârı fi 11 Safer } \\
1097\end{array}$ & $\begin{array}{l}\text { Ba-kefâlet-i Ohannes } \\
\text { Murad Madnik } \\
\text { Tezkire-dâde fî 22 Zi'l- } \\
\text { hicce sene 1096 } \\
\text { Guruş-1 esedi 5 }\end{array}$ & $\begin{array}{l}\text { Ba-kefâlet-i } \\
\text { Tavukçuoğlu } \\
\text { Giragos Haçador }\end{array}$ \\
\hline $\begin{array}{l}\text { Ba-kefâlet-i Haçador } \\
\text { Bedros Asadur }\end{array}$ & $\begin{array}{l}\text { Ba-kefâlet-i Usta } \\
\text { Hasan } \\
\text { Murad Serkiz }\end{array}$ & $\begin{array}{l}\text { Ba-kefâlet-i Kostantin } \\
\text { Kosta Sefer }\end{array}$ & $\begin{array}{l}\text { Ba-kefâlet-i Merim } \\
\text { İvaz Sefer }\end{array}$ \\
\hline $\begin{array}{l}\text { Yekûn } \\
\text { Lağımcıyân } \\
\text { Neferan 200 }\end{array}$ & \multicolumn{3}{|l}{} \\
\hline
\end{tabular}

[8]

'An-cânib-i İstanbul

\begin{tabular}{|c|c|c|c|c|c|c|c|}
\hline \multicolumn{8}{|l|}{ Neccâran } \\
\hline $\begin{array}{l}\text { Ba- } \\
\text { kefâlet-i } \\
\text { Bedros } \\
\text { Kalfa } \\
\text { Topçuoğlu } \\
\text { Ser- } \\
\text { neccâran }\end{array}$ & \multicolumn{2}{|c|}{$\begin{array}{l}\text { Ba-kefâlet-i Ömer } \\
\text { Bıçakçı } \\
\text { İvaz Esad } \\
\text { Ser-bölük }\end{array}$} & \multicolumn{2}{|c|}{$\begin{array}{l}\text { Ba-kefâlet-i Bedros } \\
\text { Kalfa } \\
\text { Gedik Sinan }\end{array}$} & \multicolumn{2}{|c|}{$\begin{array}{l}\text { Ba-kefâlet-i İvaz } \\
\text { OhannesEsad }\end{array}$} & $\begin{array}{l}\text { Ba- } \\
\text { kefâlet-i } \\
\text { Suyolcu } \\
\text { Ramazan } \\
\text { Mustafa } \\
\text { Abdullah }\end{array}$ \\
\hline \multicolumn{2}{|c|}{$\begin{array}{l}\text { Ba-kefâlet-i Kara } \\
\text { Mehmed } \\
\text { Osman Abdullah }\end{array}$} & \multicolumn{2}{|c|}{$\begin{array}{l}\text { Ba-kefâlet-i Davud } \\
\text { Kalfa } \\
\text { Bayram Yusuf }\end{array}$} & \multicolumn{2}{|c|}{$\begin{array}{l}\text { Ba-kefâlet-i ‘'̀vaz } \\
\text { Kalfa } \\
\text { Yosef Zanik }\end{array}$} & \multicolumn{2}{|c|}{$\begin{array}{l}\text { Ba-kefâlet-i Andon } \\
\text { Kalfa } \\
\text { İbrahim İyan }\end{array}$} \\
\hline \multicolumn{2}{|c|}{$\begin{array}{l}\text { Ba-kefâlet-i Giragos } \\
\text { Adriya Giragos }\end{array}$} & \multicolumn{2}{|c|}{$\begin{array}{l}\text { Ba-kefâlet-i Müferoğlu } \\
\text { Bogos Garaya }\end{array}$} & \multicolumn{2}{|c|}{$\begin{array}{l}\text { Ba-kefâlet-i Haçador } \\
\text { Penyad Haçik }\end{array}$} & \multicolumn{2}{|c|}{$\begin{array}{l}\text { Ba-kefâlet-i Artin } \\
\text { Kalfa } \\
\text { Norsez Nisogos }\end{array}$} \\
\hline \multicolumn{2}{|c|}{$\begin{array}{l}\text { Ba-kefâlet-i Haçador } \\
\text { Şahin Davud }\end{array}$} & \multicolumn{2}{|c|}{$\begin{array}{l}\text { Ba-kefâlet-i Karlo } \\
\text { Kalfa } \\
\text { Hüseyin Yusuf }\end{array}$} & \multicolumn{2}{|c|}{$\begin{array}{l}\text { Ba-kefâlet-i Bağvand } \\
\text { Haçador Ohan }\end{array}$} & \multicolumn{2}{|c|}{$\begin{array}{l}\text { Ba-kefâlet-i Karabed } \\
\text { Somata Zekeriyya }\end{array}$} \\
\hline \multicolumn{2}{|c|}{$\begin{array}{l}\text { Ba-kefâlet-i Manol } \\
\text { Kalfa } \\
\text { Yani Penayol }\end{array}$} & \multicolumn{2}{|c|}{$\begin{array}{l}\text { Ba-kefâlet-i Hamakçı } \\
\text { Rum Bey } \\
\text { Anri Arslan }\end{array}$} & \multicolumn{2}{|c|}{$\begin{array}{l}\text { Ba-kefâlet-i Bedros } \\
\text { Yousef Norsez }\end{array}$} & \multicolumn{2}{|c|}{$\begin{array}{l}\text { Ba-kefâlet-i Mekadiç } \\
\text { İvaz Karagöz }\end{array}$} \\
\hline \multicolumn{2}{|c|}{$\begin{array}{l}\text { Ba-kefâlet-i Bedros } \\
\text { Kalfa } \\
\text { İbrahim Sinan }\end{array}$} & \multicolumn{2}{|c|}{$\begin{array}{l}\text { Ba-kefâlet-i Mekadiç } \\
\text { Serkiz Orsadi }\end{array}$} & \multicolumn{2}{|c|}{$\begin{array}{l}\text { Ba-kefâlet-i Bedros } \\
\text { Kalfa } \\
\text { Pehlivan Usta }\end{array}$} & \multicolumn{2}{|c|}{$\begin{array}{l}\text { Ba-kefâlet-i Norsez } \\
\text { Karabed Yosif }\end{array}$} \\
\hline
\end{tabular}




\begin{tabular}{|c|c|c|c|}
\hline \multicolumn{2}{|l|}{$\begin{array}{l}\text { Ba-kefâlet-i Bedros } \\
\text { Arabacıoğlu Karabed } \\
\text { Ba-kefâlet-i Ohannes } \\
\text { Azadoğlu Gabril }\end{array}$} & $\begin{array}{l}\text { Ba-kefâlet-i Alton ile } \\
\text { Kiryako } \\
\text { İstokili İstorya }\end{array}$ & $\begin{array}{l}\text { Ba-kefâlet-i } \\
\text { Kırkarşunoğlu } \\
\text { Şahin Paşa }\end{array}$ \\
\hline $\begin{array}{l}\text { Ba-kefâlet-i Ohannes } \\
\text { Şahin Yosef }\end{array}$ & $\begin{array}{l}\text { Ba-kefâlet-i Hüseyin } \\
\text { Beşe } \\
\text { Şaban Mustafa }\end{array}$ & $\begin{array}{l}\text { Ba-kefâlet-i Kadıŏlu } \\
\text { Serkiz Haçador }\end{array}$ & $\begin{array}{l}\text { Ba-kefâlet-i Davud } \\
\text { Samancıoğlu }\end{array}$ \\
\hline $\begin{array}{l}\text { Ba-kefâlet-i Topçuoğlu } \\
\text { Hasan Abdullah }\end{array}$ & $\begin{array}{l}\text { Ba-kefâlet-i Topçuoğlu } \\
\text { Agob Manuk }\end{array}$ & $\begin{array}{l}\text { Yekûn Neccâran } \\
\text { Neferan } 35\end{array}$ & \\
\hline
\end{tabular}

[9]

'An-cânib-i Kazâ-i Edirne

\begin{tabular}{|c|c|c|c|}
\hline \multicolumn{4}{|l|}{ Beldârân } \\
\hline $\begin{array}{l}\text { Mahalle-i Evliya } \\
\text { Kasımpaşa } \\
\text { Mustafa bin Ahmed }\end{array}$ & $\begin{array}{l}\text { Mahalle-i Saruca Paşa } \\
\text { Mehmed bin Mustafa }\end{array}$ & $\begin{array}{l}\text { Mahalle-i Firuz } \\
\text { Şahin bin Durak }\end{array}$ & $\begin{array}{l}\text { Mahalle-i } \\
\text { Abdurrahman } \\
\text { el-Hac Mehmed bin } \\
\text { Mustafa }\end{array}$ \\
\hline $\begin{array}{l}\text { Mahalle-i Hacı Tarak } \\
\text { Yusuf bin Muharrem }\end{array}$ & $\begin{array}{l}\text { Mahalle-i Sitti Hatun } \\
\text { Kurd veled-i Estuyan }\end{array}$ & $\begin{array}{l}\text { Mahalle-i İmâret-i } \\
\text { Ferid Bey Ali bin } \\
\text { Mehmed }\end{array}$ & $\begin{array}{l}\text { Mahalle-i Ahicik } \\
\text { Hacı Ali bin Abdullah }\end{array}$ \\
\hline $\begin{array}{l}\text { Mahalle-i Alemdaran } \\
\text { Angeli veled-i Tafiri }\end{array}$ & $\begin{array}{l}\text { Mahalle-i Koduk } \\
\text { Osman } \\
\text { Mustafa bin Veli }\end{array}$ & $\begin{array}{l}\text { Mahalle-i Sabunc1 } \\
\text { Ahmed bin Mehmed }\end{array}$ & $\begin{array}{l}\text { Mahalle-i Firuz Ağa } \\
\text { Ali bin Abdullah }\end{array}$ \\
\hline $\begin{array}{l}\text { Mahalle-i İmâret-i } \\
\text { Mihal Bey } \\
\text { Hasan bin Ali } \\
\text { Ahmed bin Mehmed }\end{array}$ & $\begin{array}{l}\text { Mahalle-i Medrese-i } \\
\text { Şah Melek } \\
\text { Abdullah bin Mustafa }\end{array}$ & $\begin{array}{l}\text { Mahalle-i Hacı İslâm } \\
\text { Dilaver bin Abdullah } \\
\text { Bâ-kefâlet-i el-Hac } \\
\text { Himmetimâm-1 } \\
\text { mahalle-i m. ve } \\
\text { Muharrem Çelebi ve } \\
\text { gayrı firar ve bedeleş } \\
\text { tahsîl şod fermude } \\
\text { Ber-mûceb-i defter } \\
\text { Manastır fi } 13 \text { Receb } \\
\text { sene } 1096 \\
\text { tahsîl şod defter-i } \\
\text { Manastır fî } 13 \text { Receb } \\
96 \text { Guruş-1 esedi } 40 \\
\text { Kaydı durdu. }\end{array}$ & $\begin{array}{l}\text { Mahalle-i Debbâğ Hacı } \\
\text { Halil } \\
\text { Ahmed bin Mustafa }\end{array}$ \\
\hline $\begin{array}{l}\text { Mahalle-i Timur Biga } \\
\text { Hasan bin Mustafa }\end{array}$ & $\begin{array}{l}\text { Mahalle-i Hacı } \\
\text { Mercimek } \\
\text { İbrahim bin Mehmed }\end{array}$ & $\begin{array}{l}\text { Mahalle-i Dârü'ssiyâde } \\
\text { Veli bin Mehmed }\end{array}$ & $\begin{array}{l}\text { Mahalle-i Hacı İvaz } \\
\text { Bayram bin Süleyman }\end{array}$ \\
\hline
\end{tabular}




\begin{tabular}{|c|c|c|c|}
\hline $\begin{array}{l}\text { Mahalle-i Hamâm-1 } \\
\text { Kasım Paşa } \\
\text { Halil bin Abdülkadir }\end{array}$ & $\begin{array}{l}\text { Mahalle-i Kürd Hoca } \\
\text { Mustafa bin Arslan } \\
\text { Mustafa bin Abdullah }\end{array}$ & $\begin{array}{l}\text { Mahalle-i Mü’min } \\
\text { Hoca } \\
\text { İsmail bin Ömer }\end{array}$ & $\begin{array}{l}\text { Mahalle-i Mağruf } \\
\text { Hoca } \\
\text { Mustafa bin Murad }\end{array}$ \\
\hline $\begin{array}{l}\text { Mahalle-i Murâdiye } \\
\text { İsmail bin Ali }\end{array}$ & $\begin{array}{l}\text { Mahalle-i Çukacı } \\
\text { İvaz bin Abdullah }\end{array}$ & $\begin{array}{l}\text { Mahalle-i Kuruçeşme } \\
\text { Abdülfettah bin Sinan }\end{array}$ & $\begin{array}{l}\text { Mahalle-i Dâye Hatun } \\
\text { Kasim bin Abdullah }\end{array}$ \\
\hline $\begin{array}{l}\text { Mahalle-i Şehabeddin } \\
\text { nâm-1 diğer Kavaklı } \\
\text { Mehmed bin Ali }\end{array}$ & $\begin{array}{l}\text { Mahalle-i Bezirci } \\
\text { Hatun } \\
\text { Hasan bin İvaz }\end{array}$ & $\begin{array}{l}\text { Mahalle-i Turgud } \\
\text { Bâzergân } \\
\text { Hasan bin Halil } \\
\end{array}$ & $\begin{array}{l}\text { Mahalle-i Hazinedâr } \\
\text { Sinan Bey } \\
\text { Hüseyin bin Hasan }\end{array}$ \\
\hline $\begin{array}{l}\text { Mahalle-i Arabaci } \\
\text { Ahmed } \\
\text { Ahmed bin Abdullah }\end{array}$ & $\begin{array}{l}\text { Mahalle-i Köhnebâli } \\
\text { Mehmed bin Abdullah }\end{array}$ & $\begin{array}{l}\text { Mahalle-i Medrese-i } \\
\text { Ali Bey } \\
\text { Ahmed bin 'Ali }\end{array}$ & $\begin{array}{l}\text { Mahalle-i Câmi'-i } \\
\text { Kebîr } \\
\text { Ahmed bin Derviş }\end{array}$ \\
\hline
\end{tabular}

\section{[10]}

\begin{tabular}{|c|c|c|c|}
\hline $\begin{array}{l}\text { Mahalle-i Sarıca Paşa } \\
\text { Ömer bin Mustafa }\end{array}$ & $\begin{array}{l}\text { Mahalle-i Noktacı } \\
\text { Firâk } \\
\text { Mahmud bin Ali } \\
\end{array}$ & $\begin{array}{l}\text { Mahalle-i Karabulut } \\
\text { Mehmed bin Ali }\end{array}$ & $\begin{array}{l}\text { Mahalle-i Zincrilikuyu } \\
\text { Halil bin Hasan }\end{array}$ \\
\hline $\begin{array}{l}\text { Mahalle-i Yancıkçı } \\
\text { Şahin } \\
\text { Halil bin Ömer }\end{array}$ & $\begin{array}{l}\text { Mahalle-i Hacı Hallâç } \\
\text { Mustafa bin Mehmed }\end{array}$ & $\begin{array}{l}\text { Mahalle-i Vizeli Çelebi } \\
\text { Perviz bin Abdullah }\end{array}$ & $\begin{array}{l}\text { Mahalle-i Derzi Ağa } \\
\text { Ali bin Ahmed }\end{array}$ \\
\hline $\begin{array}{l}\text { Mahalle-i Garâz Salih } \\
\text { Ali bin Ahmed }\end{array}$ & $\begin{array}{l}\text { Mahalle-i Mahmud } \\
\text { Ağa } \\
\text { Ali bin Mehmed }\end{array}$ & $\begin{array}{l}\text { Mahalle-i Derviş Abi } \\
\text { Yusuf bin Abdullah } \\
\text { Ba-kefâlet-i İmam Ali } \\
\text { Efendi ve Bağlamur } \\
\text { Hacı Mehmed ve Ali } \\
\text { Firâr ve bedeleş } \\
\text { tahsîlşod fermude } \\
\text { ber-mûceb-i defter-i } \\
\text { Manastır fi } 13 \text { Receb } \\
\text { sene } 1096 \\
\text { tahsîl şod defter-i } \\
\text { Manastır fî } 13 \text { Receb } \\
96 \text { Guruş-1 esedi } 40 \\
\text { Kaydı durdu. }\end{array}$ & $\begin{array}{l}\text { Mahalle-i Hızır Ağa } \\
\text { Sefer bin Abdullah }\end{array}$ \\
\hline $\begin{array}{l}\text { Mahalle-i Emirşah } \\
\text { Şaban bin Himmet }\end{array}$ & $\begin{array}{l}\text { Mahalle-i Baba } \\
\text { Timurtaş } \\
\text { Bali bin Derviş }\end{array}$ & $\begin{array}{l}\text { Mahalle-i Şehabeddin } \\
\text { Paşa } \\
\text { Der-mahalle-i Arâsta } \\
\text { İvaz bin Abdullah }\end{array}$ & $\begin{array}{l}\text { Mahalle-i Hoca Ali } \\
\text { Kasar veled-i Markar }\end{array}$ \\
\hline $\begin{array}{l}\text { Mahalle-i Üsküfçü } \\
\text { Hızır } \\
\text { Ahmed bin Hızır }\end{array}$ & $\begin{array}{l}\text { Mahalle-i Gazi Hoca } \\
\text { Hasan bin Bazarlı }\end{array}$ & $\begin{array}{l}\text { Mahalle-i Çakır Ağa } \\
\text { Mehmed bin Süleyman }\end{array}$ & $\begin{array}{l}\text { Mahalle-i Kssasâb } \\
\text { Abdülaziz } \\
\text { Sadık Mehmed bin Ali }\end{array}$ \\
\hline $\begin{array}{l}\text { Mahalle-i Findık Fakih } \\
\text { Ali bin Mehmed }\end{array}$ & $\begin{array}{l}\text { Mahalle-i Köse } \\
\text { Balaban } \\
\text { Dimitri veled-i Todori }\end{array}$ & $\begin{array}{l}\text { Mahalle-i Kınc1 Firuz } \\
\text { Yovanveled-i Kirkor }\end{array}$ & $\begin{array}{l}\text { Mahalle-i Hasan Paşa } \\
\text { Mustafa bin Abdullah }\end{array}$ \\
\hline
\end{tabular}




\begin{tabular}{|c|c|c|}
\hline $\begin{array}{l}\text { Mahalle-i Zen-i } \\
\text { İbrahim Paşa } \\
\text { Hüseyin bin Maden }\end{array}$ & $\begin{array}{l}\text { Mahalle-i Rakkâs Ali } \\
\text { Bey } \\
\text { Na'l-bend Yakub } \\
\text { veled-i Toma }\end{array}$ & $\begin{array}{l}\text { Mahalle-i Zimmiyân } \\
\text { İstefani veled-i Miho } \\
\text { Nağo veled-i Marşo } \\
\text { İstefani veled-i Nedelko } \\
\text { Yovan veled-i Todori } \\
\text { Braşkon veled-i Peter } \\
\text { Neferan } 5\end{array}$ \\
\hline \multicolumn{3}{|l|}{ Mahalle-i Yehûdiyân } \\
\hline \multicolumn{3}{|l|}{ Ahmed bin Abdullah } \\
\hline \multicolumn{3}{|l|}{ Manol veled-i Dimitri } \\
\hline \multicolumn{3}{|l|}{ Pavlo veled-i Yorgi } \\
\hline \multicolumn{3}{|c|}{ Nikola veled-I İsta[ni]mir } \\
\hline \multicolumn{3}{|c|}{ Dimitri veled-i Nikola } \\
\hline \multicolumn{3}{|l|}{ Şahin veled-i Prodan } \\
\hline \multicolumn{3}{|l|}{ Vartan veled-i Asadur } \\
\hline \multicolumn{3}{|l|}{ Yovan veled-i İgnad } \\
\hline \multicolumn{3}{|l|}{ Hristo veled-i Tono } \\
\hline \multicolumn{3}{|l|}{ Yani veled-i Kosta } \\
\hline \multicolumn{3}{|l|}{ Dimitri veled-i Nikola } \\
\hline \multicolumn{3}{|l|}{ Neferan 11} \\
\hline \multicolumn{3}{|c|}{ Ba-kefâlet-i Saha veled-i Yako ve Demirci veled-i Haylamon ve gayrı } \\
\hline \multicolumn{3}{|c|}{$\begin{array}{l}\text { Firâr ve bedeleş tahsîl şod fermude ber-mûceb-i defter Manastır fi } 13 \text { Receb sene } 1096 \text { tahsîl şod } \\
\text { defter-i Manastır fî } 13 \text { Receb } 1096\end{array}$} \\
\hline \multicolumn{3}{|c|}{ Guruş-1 esedi 40} \\
\hline Kaydı durdu. & & \\
\hline
\end{tabular}

\begin{tabular}{|c|c|c|}
\hline \multicolumn{3}{|c|}{ Nâhiye-i Ada tâbi'-i Kazâ-i Edirne } \\
\hline $\begin{array}{l}\text { Karye-i Ahur ve gayrı } \\
\text { Bekir bin Bali } \\
\text { 'an-karye-i Umurbeyli } \\
\text { Hızır bin İlyas } \\
\text { 'an-karye-i Hatib } \\
\text { Neferan: } 2\end{array}$ & $\begin{array}{l}\text { Karye-i Şahin ve gayrı } \\
\text { Kurd veled-i Bogaki'an-karye-i Kara } \\
\text { Öyuk } \\
\text { İsmail bin Abdullah } \\
\text { 'an-hizmet-i Za'îm Ahmed Ağa-i Beldâr } \\
\text { Kara Derviş } \\
\text { Firâr ve bedeleş tahsîl şod fermude ber- } \\
\text { mûceb-i defter-i Manastır fi } 13 \text { Receb } \\
\text { sene } 1096 \\
\text { tahsîl şod defter-i Manastır fî } 13 \text { Receb } \\
96 \\
\text { Guruş-1 esedi } 40 \\
\text { Kaydı durdu. } \\
\text { Ba-kefâlet-i Abalı veled-i Zahir'an- } \\
\text { karye-i Doğâncı }\end{array}$ & $\begin{array}{l}\text { Karye-i Açesultan ve } \\
\text { gayrihu } \\
\text { Ömer Bey bin Ali } \\
\text { Mustafa bin Ali } \\
\text { 'an-hizmet-i Ağa-y1 } \\
\text { Beldâr }\end{array}$ \\
\hline
\end{tabular}


[11]

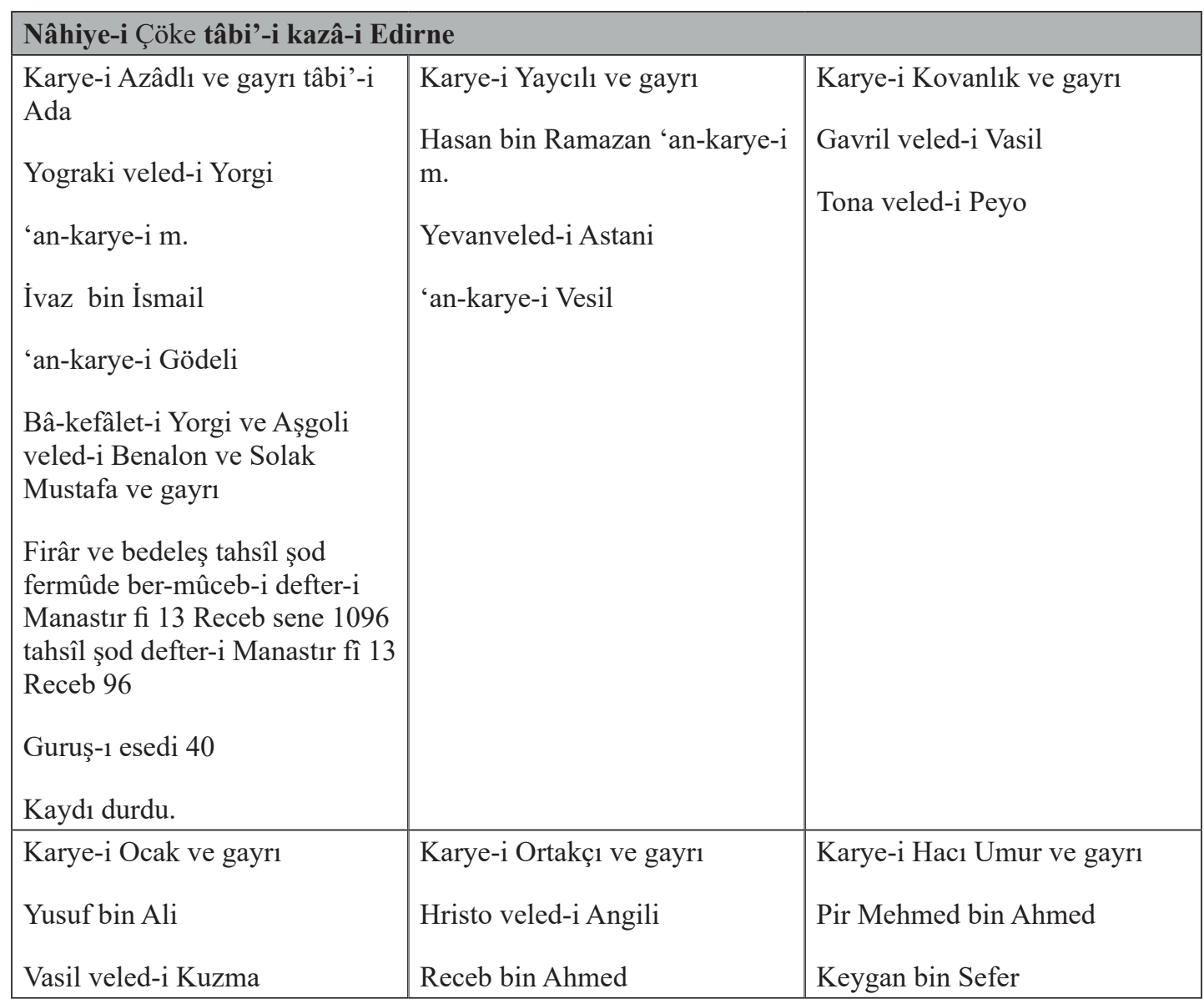

\begin{tabular}{|c|c|c|}
\hline \multicolumn{3}{|l|}{ Nâhiye-i Üsküdar } \\
\hline $\begin{array}{l}\text { Karye-i Maraş ve gayrı } \\
\text { Ahmed bin Abdullah } \\
\text { Nasib bin Abdullah }\end{array}$ & $\begin{array}{l}\text { Karye-i Nefs-i Üsküdâr ve gayrı } \\
\text { Yovan veled-i Petko } \\
\text { Manoli veled-i İstoyan } \\
\text { Ba-kefâlet-i Budakoğlu Dudu ve } \\
\text { Halaso oğlu Hanik ve gayrı } \\
\text { Firâr ve bedeleş tahsîl şod fermude } \\
\text { ber-mûceb-i defter- i Manastır fi } 13 \\
\text { Receb sene } 1096 \\
\text { tahsîl şod defter-i Manastır fî } 13 \\
\text { Receb } 1096 \text { Guruş-1 esedi } 40 \\
\text { Kaydı durdu. }\end{array}$ & $\begin{array}{l}\text { Karye-i Kayı ve gayrı } \\
\text { Dimo veled-i Hristo } \\
\text { Yani veled-i Toma }\end{array}$ \\
\hline $\begin{array}{l}\text { Karye-i Kızılcıklı ve gay } \\
\text { Yakub bin Hasan Dede } \\
\text { Mardiros veled-i Kirkor }\end{array}$ & \multicolumn{2}{|c|}{\begin{tabular}{|l|l} 
Karye-i Güdmeve gayrı \\
Yorgi veled-i Miho \\
Manuk veled-i Kirkor
\end{tabular}} \\
\hline
\end{tabular}




\begin{tabular}{|c|c|c|c|c|c|}
\hline \multicolumn{6}{|c|}{ Nâhiye-i Manastır tâbi’-i kazâ-i Edirne } \\
\hline $\begin{array}{l}\text { Karye-i Kafirsinekli ve } \\
\text { gayrı } \\
\text { Kosta veled-i Yorgo } \\
\text { Mehmed bin Mustafa } \\
\text { Bâ-kefâlet-i Emir } \\
\text { Mustafa an-karye-i } \\
\text { Kavaklı ve Hristo } \\
\text { veled-i Yorgo ve gayrı } \\
\text { Firâr ve bedeleş } \\
\text { tahsîl şod fermude } \\
\text { ber-mûceb-i defter-i } \\
\text { Manastır fi } 13 \text { Receb } \\
\text { sene } 1096 \\
\text { tahsîl şod defter-i } \\
\text { Manastır fî } 13 \text { Receb } 96 \\
\text { Guruş-1 esedi } 40 \\
\text { Kaydı durdu. }\end{array}$ & \multicolumn{2}{|c|}{$\begin{array}{l}\text { Karye-i Manastır-1 Kebîr ve } \\
\text { gayrı } \\
\text { Todor Dimo veled-i Vaso } \\
\text { Miho veled-i Dimo }\end{array}$} & \multicolumn{2}{|c|}{$\begin{array}{l}\text { Karye-i Kalkanoğlu } \\
\text { ve gayrı } \\
\text { Hasan bin Mustafa } \\
\text { Beypazarı } \\
\text { Velko veled-i Delo }\end{array}$} & $\begin{array}{l}\text { Karye-i Kozanca } \\
\text { ve gayrı } \\
\text { Mustafa bin } \\
\text { Abdullah } \\
\text { İsvedko veled-i } \\
\text { Yovan, } \\
\text { Ber-hizmet Ağa-i } \\
\text { beldarân }\end{array}$ \\
\hline $\begin{array}{l}\text { Karye-i Kevakin ve } \\
\text { gayrı } \\
\text { Tano veled-i Istoyan } \\
\text { Yano veled-i Mavridi }\end{array}$ & \multicolumn{2}{|c|}{$\begin{array}{l}\text { Nâhiye-i Cisr-i Mustafa Paşa } \\
\text { Mahalle-i Câmi-i Kebîr } \\
\text { Hasan bin Mehmed } \\
\text { Şahin bin Abdullah }\end{array}$} & \multicolumn{3}{|c|}{$\begin{array}{l}\text { Yekûn } \\
\text { Neferan:120 }\end{array}$} \\
\hline \multicolumn{6}{|c|}{$\begin{array}{l}\text { Minhâ } \\
\text { Firârân } \\
\text { Firâr ve bedeleş tahsîl şod fermude ber-mûceb-i defter-i Manastır fi } 13 \text { Receb sene } 1096 \text { tahsîl şod } \\
\text { defter-i Manastır fî } 13 \text { Receb } 1096\end{array}$} \\
\hline \multicolumn{2}{|c|}{ Neferan } & \multicolumn{2}{|c|}{ Guruş-1 esedi } & \\
\hline \multicolumn{2}{|l|}{1} & \multicolumn{2}{|l|}{40} & \multicolumn{2}{|c|}{ 'an-mahalle-i Hacıİslâm } \\
\hline \multicolumn{2}{|l|}{1} & \multicolumn{2}{|l|}{40} & \multicolumn{2}{|c|}{ 'an -mahalle-i Derviş Bali } \\
\hline \multicolumn{2}{|l|}{1} & \multicolumn{2}{|l|}{40} & \multicolumn{2}{|c|}{ 'an -mahalle-i Yahudiyân } \\
\hline \multicolumn{2}{|l|}{1} & \multicolumn{2}{|l|}{40} & \multicolumn{2}{|c|}{ 'an-karye-i Şahince tâbi'-i Ada } \\
\hline \multicolumn{2}{|l|}{1} & \multicolumn{2}{|l|}{40} & \multicolumn{2}{|c|}{ 'an-karye-i Azadlı tâbi'-i Çöke } \\
\hline \multicolumn{2}{|l|}{1} & \multicolumn{2}{|l|}{40} & \multicolumn{2}{|c|}{ 'an -karye-i nefs-i Üsküdâr } \\
\hline \multicolumn{2}{|l|}{1} & \multicolumn{2}{|l|}{40} & \multicolumn{2}{|c|}{$\begin{array}{l}\text { 'an-karye-i Kafirsinekli tâbi'-i } \\
\text { Manastır }\end{array}$} \\
\hline 7-1=6 Toplam & & $\begin{array}{l}280-40=240 \mathrm{~F} \\
\text { tahsîl şod=Zîr } \\
\text { yol mahallind } \\
\text { mukayyeddir. }\end{array}$ & rmude & & \\
\hline
\end{tabular}




\section{[12]}

'An-cânib-i kazâ-i Niğde

Lağımcıyân

Neferan: 30

\begin{tabular}{|c|c|c|c|}
\hline $\begin{array}{l}\text { Karye-i Naynas } \\
\text { Şaban bin Bayram } \\
\text { Bâ-kefâlet-i Kara } \\
\text { Hasan bin Ali } \\
\text { 'an-mahalle-i Bali } \\
\text { Hasan } \\
\text { Tezkire-dâde fi } 22 \text { m. } \\
\text { sene } 1096 \\
\text { Guruş-1 esedi } 5\end{array}$ & $\begin{array}{l}\text { Karye-i İloson } \\
\text { Mevlüd bin Hüseyin } \\
\text { Bâ-kefâlet-i Eyüb } \\
\text { Fakih imâm-1 mahalle-i } \\
\text { mezbûr }\end{array}$ & $\begin{array}{l}\text { Karye-i Naynas } \\
\text { Süleyman bin Gödegi } \\
\text { Bölükbaşı } \\
\text { Bâ-kefâlet-i Halil } \\
\text { Çelebi ibn-i Mustafa } \\
\text { 'an-mahalle-i Ayas Ağa }\end{array}$ & $\begin{array}{l}\text { Karye-i Germiyan } \\
\text { Receb bin Mustafa } \\
\text { Bâ-kefâlet-i Halil } \\
\text { Çelebi ibn-i Mustafa } \\
\text { el-mezbûr sâkin } \\
\text { mahalle-i Ayas Ağa }\end{array}$ \\
\hline $\begin{array}{l}\text { Karye-i Naynas } \\
\text { Durali bin Abdülcelil } \\
\text { Bâ-kefâlet-i merkûm } \\
\text { Halil Çelebi‘an- } \\
\text { mahalle-i Ayas Ağa }\end{array}$ & $\begin{array}{l}\text { Karye-i Naynas } \\
\text { Şaban bin Yusuf } \\
\text { Bâ-kefâlet-i Abdullah } \\
\text { bin Bayezid 'an- } \\
\text { karye-i Adırmason } \\
\text { Tezkire dade sene m. } \\
\text { Kefîli } 5\end{array}$ & $\begin{array}{l}\text { Mahalle-i Hassa } \\
\text { Ömer bin Ali } \\
\text { Bâ-kefâlet-i Hacı } \\
\text { Himmet el-hisâr 'an- } \\
\text { mahalle-i mezbûr }\end{array}$ & $\begin{array}{l}\text { Mahalle-i Ahenger } \\
\text { Sevindik bin Ali } \\
\text { Bâ-kefâlet-i Himmet } \\
\text { veled-i o veYusuf bin } \\
\text { Abdullah 'an-mahalle-i } \\
\text { mezbûr }\end{array}$ \\
\hline $\begin{array}{l}\text { Karye-i Germiyan } \\
\text { Mehmed bin Hüseyin } \\
\text { Kefîli } \\
\text { Bâ-kefâlet-i Mir Veli } \\
\text { bin Mir Hoca ve } \\
\text { Mehmed bin Mus 'an- } \\
\text { mahalle-i mezbûr }\end{array}$ & $\begin{array}{l}\text { Karye-i Firuzlı } \\
\text { Ali bin Nasuh } \\
\text { Bâ-kefâlet-i Nasuh } \\
\text { peder-i mezbûr }\end{array}$ & $\begin{array}{l}\text { Karye-i Ören } \\
\text { Mehmed bin } \\
\text { Abdurrahman } \\
\text { Bâ-kefâlet-i Abdullah } \\
\text { bin Halil } \\
\text { 'an-mahalle-i Önger } \\
\text { ve Mahmud ve } \\
\text { Abdurrahman 'an- } \\
\text { karye-i mezbûr }\end{array}$ & $\begin{array}{l}\text { Karye-i Güllüce } \\
\text { Mevlüd bin Süleyman } \\
\text { Bâ-kefâlet-i Mahmud } \\
\text { bin Alive Süleyman bin } \\
\text { Üveys 'an-mahalle-i } \\
\text { mezbûr }\end{array}$ \\
\hline $\begin{array}{l}\text { Karye-i Naynas } \\
\text { Mustafa bin Mehmed } \\
\text { Bâ-kefâlet-i Mahmud } \\
\text { bin Mehmed ve } \\
\text { Abdullah Çelebi ibn-i } \\
\text { İvaz Efendi }\end{array}$ & $\begin{array}{l}\text { Karye-i Naynas } \\
\text { Mehmed bin Himmet } \\
\text { Bâ-kefâlet-i Keçeçi } \\
\text { İvaz bin Osman'an- } \\
\text { mahalle-i Kayabaşı }\end{array}$ & $\begin{array}{l}\text { Karye-i Üçhisâr 'an- } \\
\text { kazâ-i Ürgüb } \\
\text { Abdurrahman bin } \\
\text { Yusuf } \\
\text { Bâ-kefâlet-i Mustafa } \\
\text { bin Ahmed 'an- } \\
\text { mahalle-i câmi'-i } \\
\text { Sultan }\end{array}$ & $\begin{array}{l}\text { Mahalle-i Kuba } \\
\text { Mehmed bin Hasan } \\
\text { Tezkire-dâde fi } 22 \text { Zi'l- } \\
\text { hicce } \\
\text { Guruş-1 esedi } 5 \\
\text { Bâ-kefâlet-i Ali bin } \\
\text { Feyyaz 'an-mahalle-i } \\
\text { mezbûr ve Pir Ali } \\
\text { bin Hacı Hasan 'an- } \\
\text { mahalle-i Hoca Karaca }\end{array}$ \\
\hline
\end{tabular}




\begin{tabular}{|c|c|c|c|}
\hline $\begin{array}{l}\text { Mahalle-i Kasım } \\
\text { Mehmed bin İbrahim } \\
\text { Bâ-kefâlet-i Süleyman } \\
\text { bin Süleyman ve } \\
\text { Hüseyin bin Hacı } \\
\text { Hasan 'an-mahalle-i } \\
\text { Sirkapalı }\end{array}$ & $\begin{array}{l}\text { Mahalle-i Kıble } \\
\text { İbrahim bin Rıdvan } \\
\text { Bâ-kefâlet-i Uncuoğlu } \\
\text { Hallâc Ahmed } \\
\text { Der-kenârı fi } 27 \text { Safer }\end{array}$ & $\begin{array}{l}\text { Mahalle-i Önik } \\
\text { Mehmed bin Abdüllatif } \\
\text { Bâ-kefâlet-i Ramazan } \\
\text { bin Süleyman'an- } \\
\text { mahalle-i mezbûr }\end{array}$ & $\begin{array}{l}\text { Karye-i Melik Ova } \\
\text { Hamid bin Ahmed } \\
\text { Bâ-kefâlet-i İmâm Hacı } \\
\text { Mustafa bin Osman ve } \\
\text { Cafer bin Bayram ve } \\
\text { Şaban bin Kasım‘an- } \\
\text { karye-i mezbûr }\end{array}$ \\
\hline $\begin{array}{l}\text { Karye-i Naynas } \\
\text { Üveys bin Cafer } \\
\text { Bâ-kefâlet-i Mehmed } \\
\text { bin Musa'an-karye-i } \\
\text { Gelemiç }\end{array}$ & $\begin{array}{l}\text { Mahalle-i Kayabaşı } \\
\text { Koreska bin Sefer } \\
\text { Bâ-kefâlet-i Zımmî } \\
\text { Bilyan veled-i Giregos } \\
\text { Ber mahalle-i mezbur }\end{array}$ & $\begin{array}{l}\text { Karye-i Ören } \\
\text { Abdullah bin Ömer } \\
\text { Bâ-kefâlet-i } \\
\text { Abdülkadir bin Ömer } \\
\text { ve Nefi Abdülkâdir‘an- } \\
\text { karye-i mezbûr } \\
\text { Tezkire-dâde fi } 17 \\
\text { Safer sene } 1097 \\
\text { Guruş-1 esedi } 5\end{array}$ & $\begin{array}{l}\text { Mahalle-i Kasım } \\
\text { Halil bin Ömer } \\
\text { Bâ-kefâlet-i Ömer } \\
\text { Derviş ve Ahmed } \\
\text { Biradereş } \\
\text { Tezkire-dâde fi Zi’l- } \\
\text { hicce } \\
\text { Guruş-1 esedi } 5\end{array}$ \\
\hline $\begin{array}{l}\text { Karye-i Ören } \\
\text { İbrahim bin } \\
\text { Abdurrahman } \\
\text { Der-kenârı } 27 \text { Safer } \\
\text { Bâ-kefâlet-i Halil bin } \\
\text { Hüseyin 'an-mahalle-i } \\
\text { Akkere ve Hasan } \\
\text { bin Hızır 'an-karye-i } \\
\text { Melikreva }\end{array}$ & $\begin{array}{l}\text { Mahalle-i Rustem } \\
\text { Ebubekir bin Osman } \\
\text { Bâ-kefâlet-i merkûm } \\
\text { OsmanDerviş }\end{array}$ & $\begin{array}{l}\text { Mahalle-i Hatîb } \\
\text { Halil bin Osman } \\
\text { Bâ-kefâlet-i } \\
\text { Osman Derviş ve } \\
\text { Seyyid Kasım ibn-i } \\
\text { Abdurrahman }\end{array}$ & $\begin{array}{l}\text { Mahalle-i Ali Bey } \\
\text { Mehmed bin es-Seyyid } \\
\text { Ali } \\
\text { Bâ-kefâlet-i Seyyid } \\
\text { Ahmed binel-Hac } \\
\text { Himmet }\end{array}$ \\
\hline $\begin{array}{l}\text { Karye-i Naynas } \\
\text { Ebubekir bin Ahmed } \\
\text { Bâ-kefâlet-i Hasan bin } \\
\text { Mehmed 'an-karye-i } \\
\text { Ayan }\end{array}$ & $\begin{array}{l}\text { Karye-i Adırmason } \\
\text { Osman bin Ahmed } \\
\text { Habib } \\
\text { Tezkire-dâde fi } 22 \text { Zi'l- } \\
\text { hicce sene } 1096 \\
\text { Guruş-1 esedi } 5 \\
\text { Bâ-kefâlet-i Hacı Ali } \\
\text { bin Seyyid Osman'an- } \\
\text { karye-i Naynas }\end{array}$ & $\begin{array}{l}\text { Minhâ } \\
\text { Lağımcıyân Neferan } \\
30 \\
\text { 'an-ahâli-i kazâ-i } \\
\text { mezbûre bâ defter-i } \\
\text { Mahmud es-Seyyid } \\
\text { Mehmed el-kâdı be- } \\
\text { medîne-i Niğde fî } \\
\text { evâhir Receb sene } \\
1096 \text { kayd şod fermude } \\
\text { fî } 13 \text { Cemâziyye'l-ahir } \\
\text { sene } 1096 \text { 'an-bedel-i } \\
\text { Mehmed Ağa Neferan } \\
30 \text { Guruş-1 esedi } 1500\end{array}$ & \\
\hline
\end{tabular}




\section{[13]}

'An-cânib-i kazâ-i Kayseri[yye]

Mübâşir Ahmed Ağa ber-mûceb-i defter-i memhûr Ramazan kâd1-1 Kayseri

\section{Lağımciyân Neferan}

Nefer-i Kazâ-i Kayseriyye

\begin{tabular}{|c|c|c|}
\hline \multicolumn{3}{|l|}{ 'An-mahallât-ı Müslümânân } \\
\hline $\begin{array}{l}\text { Mahalle-i Kepe (Gebe) İlyas } \\
\text { 'an-Cemâ'at-i Bali Fakih } \\
\text { Mustafa bin Mehmed } \\
\text { Tezkire-dâde fi } 22 \text { Zi'l-hicce } \\
\text { sene } 1096 \text { Guruş-1 esedi } 5 \\
\text { Ali bin Musa } \\
\text { Tezkire-dâde fi } 22 \text { Zi'l-hicce } \\
\text { sene } 1096 \text { Guruş-1 esedi } 5 \\
\text { Bâ-kefâlet-i Ebu'l-Müslim } \\
\text { bin İtimad Mehmed bin } \\
\text { Süleyman mezbûrlara dahi } \\
\text { ahâl-i mahalle kefîllerdir. }\end{array}$ & $\begin{array}{l}\text { Mahalle-i Kürtler ma'a Hacı } \\
\text { Abdullah ve gayrı } \\
\text { Ali bin Ferhad 'an-mahalle-i m. } \\
\text { Tezkire-dâde f } 22 \text { Zi'l-hicce sene } \\
1096 \text { Guruş-1 esedi } 5 \\
\text { Abbas bin Abdülkadir'an-mahalle-i } \\
\text { Bağçıvân } \\
\text { Bâ-kefâlet-i Molla Ömer bin Ebu'l- } \\
\text { Kasım ve Ali bin el-HacYusuf } \\
\text { ve Mehmed bin Abdülkerim ve } \\
\text { Ebubekir bin Mehmed 'an-mahalle-i } \\
\text { m. } \\
\text { Mezbûrlara dahi ahâli-i mahalle } \\
\text { kefîllerdir. }\end{array}$ & $\begin{array}{l}\text { Mahalle-i Hasan Fakih } \\
\text { Abbas bin Abdülkadir } \\
\text { Bâ-kefâlet-i mezbûr } \\
\text { AbdülkadirBerduş mezbûra } \\
\text { dahi ahâli-i mahalle } \\
\text { kefîldirler. }\end{array}$ \\
\hline $\begin{array}{l}\text { Mahalle-i Bozatlu ma'a Baba } \\
\text { Hüseyin bin Ali } \\
\text { Tezkire-dâde fi } 22 \text { Zi'l-hicce } \\
\text { sene } 1096 \text { Guruş-1 esedi } 5 \\
\text { Ahmed bin Allahverdi 'an- } \\
\text { mahalle-i Mükremin } \\
\text { Bâ-kefâlet-i el-Hac Halid } \\
\text { bin el-Hac Hüseyin ve Yusuf } \\
\text { bin Abdullah ve Mükremin } \\
\text { İbrahim mezbûrlara dahi } \\
\text { ahâli-i mahalle kefîldirler. }\end{array}$ & $\begin{array}{l}\text { Mahalle-i Huvând } \\
\text { Ser-bölük Yusuf bin Abdullah } \\
\text { Tezkire-dâde fi } 22 \text { Zi’l-hicce sene } \\
1096 \text { Guruş-1 esedi } 5 \\
\text { Bâ-kefâlet-i İmâm-1 mahalle-i } \\
\text { mezbûr ve mersûna dahi mahalle } \\
\text { ahâlisi kefîldirler. }\end{array}$ & $\begin{array}{l}\text { Mahalle-i Depecik ma'a } \\
\text { Hacetma'a Konaklar } \\
\text { Veli bin Yusuf 'an-mahalle-i m. } \\
\text { Tezkire-dâde fi } 22 \text { Zi'l-hicce } \\
\text { sene } 1096 \text { Guruş-1 esedi } 5 \\
\text { Bâ-kefâlet-i Mustafa bin } \\
\text { (boş) ve Himmet bin Hacı } \\
\text { Mehmed 'an-mahalle-i m. } \\
\text { mezbûrlara dahi mahalle } \\
\text { ahâlisi kefîldir. }\end{array}$ \\
\hline $\begin{array}{l}\text { Mahalle-i Merkebciler ma'a } \\
\text { Dânişmend ma'a Alâca } \\
\text { mescid ve Hacı İvaz ve } \\
\text { Kapan ve gayrı } \\
\text { Mustafa bin Üveys 'an- } \\
\text { mahalle-i Hasan Fakih } \\
\text { Tezkire-dâde fi } 22 \text { Zi'l-hicce } \\
\text { sene } 1096 \text { Guruş-1 esedi } 5 \\
\text { Bâ-kefâlet-i Abdülkerim bin } \\
\text { el-Hac Hakir 'an-mahalle-i } \\
\text { Depecik mezbûra dahi } \\
\text { mahallesi ahâlisi kefîldirler. }\end{array}$ & $\begin{array}{l}\text { Mahalle-i el-Hac Kılınç } \\
\text { Hüseyin bin Çelebi 'an-mahalle-i m. } \\
\text { 'An-kefâlet-i -i Çelebi Varad } \\
\text { mezbûra dahi ahâli-i mahalle } \\
\text { kefîldir. }\end{array}$ & $\begin{array}{l}\text { Mahalle-i Gülek } \\
\text { Ömer bin el-Hac Hüseyin } \\
\text { 'an-mahalle-i m. } \\
\text { Tezkire-dâde fi } 22 \text { Zi'l-hicce } \\
\text { sene } 1096 \text { Guruş-1 esedi } 5 \\
\text { Bâ-kefâlet-i Osman bin } \\
\text { Mehmed 'an-mahalle-i } \\
\text { mezbûr mezbûra dahi } \\
\text { mahalle ahâlisi kefîldirler. }\end{array}$ \\
\hline
\end{tabular}




\begin{tabular}{|c|c|c|}
\hline $\begin{array}{l}\text { Mahalle-i Taşkıncık } \\
\text { Ahmed bin Ramazan 'an- } \\
\text { mahalle-i m. } \\
\text { Tezkire-dâde fi } 22 \text { Zi'l-hicce } \\
\text { sene } 1096 \text { Guruş-1 esedi } 5 \\
\text { Bâ-kefâlet-i Yusuf birâderi o } \\
\text { merkûma dahi mahalle ahâlisi } \\
\text { kefîldir. }\end{array}$ & $\begin{array}{l}\text { Mahalle-i Karakürkcü ma'a câmi-i } \\
\text { kebîr } \\
\text { Mehmed bin Mustafa 'an-mahalle-i } \\
\text { Semecilü } \\
\text { Tezkire-dâde fi } 22 \text { Zi'l-hicce sene } \\
1096 \text { Guruş-1 esedi } 5 \\
\text { Bâ-kefâlet-i Musa bin Ali ‘an- } \\
\text { mahalle-i m. mezbûra dahi } \\
\text { mahallesi ahâlisi kefîldirler. }\end{array}$ & $\begin{array}{l}\text { Mahalle-i Hasbek ma'a Tus } \\
\text { Hüseyin bin Mustafa 'an- } \\
\text { karye-i Rûmiyân } \\
\text { Yakub bin Mahmud } \\
\text { 'an mahalle-i Hasbey } \\
\text { Der-kenârı fi } 15 \text { Safer sene } \\
1097 \\
\text { Tezkire-dâde fi } 22 \text { Zi'l-hicce } \\
\text { sene } 1096 \text { Guruş-1 esedi } 5 \\
\text { Bâ-kefâlet-i Nasib bin } \\
\text { Abdurrahman 'an-mahalle-i } \\
\text { Huvând el-Hac Osman ve Ali } \\
\text { Kethüdâ Mahalle-i Hasbey } \\
\text { mezbûrlara dahi mahalleleri } \\
\text { ahâlisi dahi kefildirler }\end{array}$ \\
\hline $\begin{array}{l}\text { Mahalle-i Şeyh Tâc ma'a } \\
\text { Emir Sultan ve gayrı } \\
\text { Veli bin Kasım‘an-mahalle-i } \\
\text { Bozatlu } \\
\text { Tezkire-dâde fi } 22 \text { Zi'l-hicce } \\
\text { sene } 1096 \text { Guruş-1 esedi } 5 \\
\text { Bâ-kefâlet-i mezbûr Kasım } \\
\text { Berduş mezbûra dahi mahalle } \\
\text { ahâlisi kefîldir. }\end{array}$ & $\begin{array}{l}\text { Mahalle-i Mükremin ve gayrı } \\
\text { Osman bin Eyüb 'an-mahalle-i m. } \\
\text { Tezkire-dâde fi } 22 \text { Zi'l-hicce sene } \\
1096 \text { Guruş-1 esedi } 5 \\
\text { Bâ-kefâlet-i mezbûr Eyüb Berduş } \\
\text { mezbûra dahi mahallesi ahâlisi } \\
\text { kefîldirler. }\end{array}$ & $\begin{array}{l}\text { Mahalle-i Yenice ma'a } \\
\text { Yalman ma'a Mumcu Halil } \\
\text { Ali bin Ali 'an-mahalle-i m. } \\
\text { Tezkire-dâde fi } 22 \text { Zi'l-hicce } \\
\text { sene } 1096 \\
\text { Guruş-1 esedi } 5 \\
\text { Mehmed bin Mehmed 'an- } \\
\text { mahalle-i m.Tezkire-dâde } \\
\text { fi } 22 \text { Zi'l-hicce sene } 1096 \\
\text { Guruş-1 esedi } 5 \\
\text { Bâ-kefâlet-i Monla Mehmed } \\
\text { bin 'Ali ve Ömer bin Nazır } \\
\text { mezbûrlara dahi ahâli-i } \\
\text { mahalle kefîldir. }\end{array}$ \\
\hline
\end{tabular}




\begin{tabular}{|c|c|c|}
\hline $\begin{array}{l}\text { Mahalle-i Semercilü } \\
\text { Ömer bin el-HacAli 'an- } \\
\text { mahalle-i m. } \\
\text { Tezkire-dâde fi } 22 \text { Zi'l-hicce } \\
\text { sene } 1096 \text { Guruş-1 esedi } 5 \\
\text { Bâ-kefâlet-i Yusuf bin } \\
\text { Ramazan mezbûra dahi } \\
\text { ahâli-i mahalle kefîldir. }\end{array}$ & $\begin{array}{l}\text { Mahalle-i Hasanilü ma'a Seydi } \\
\text { Yadigarlar } \\
\text { Mehmed bin el-Hac Hasan 'an- } \\
\text { mahalle-i Kepe (Gebe) İlyas } \\
\text { Tezkire-dâde fi } 22 \text { Zi'l-hicce sene } \\
1096 \\
\text { Guruş-1 esedi } 5 \\
\text { Veli bin Kuli'an-mahalle-i Hasanilü } \\
\text { Tezkire-dâde fi } 22 \text { Zi'l-hicce sene } \\
\text { 1096 Guruş-1 esedi } 5 \\
\text { Dilaver bin Abdullah 'an-kazâ-i } \\
\text { Gedikçubuk Tezkire-dâde fi } 22 \text { Zi'l- } \\
\text { hicce sene } 1096 \\
\text { Guruş-1 esedi } 5 \\
\text { Bâ-kefâlet-i el-Hac İbrahim bin } \\
\text { Abdullah 'an-mahalle-i Haci K1lıç } \\
\text { ve Seyyid Mahmud bin Halil 'an- } \\
\text { mahalle-i Hasanilü ve Seyyid Ali } \\
\text { Çelebi ibn-i Ömer 'an-mahalle-i } \\
\text { Kepe (Gebe) İlyas ve mezbûrlara } \\
\text { dahi mahalleleri ahâlisi kefîldirler. }\end{array}$ & $\begin{array}{l}\text { Mahalle-i Tütün ma'a Gürcü } \\
\text { ma'a Hacı Mansur } \\
\text { Abdülkadir bin Abdülkerim } \\
\text { 'an-mahalle-i Bağçıân } \\
\text { Tezkire-dâde fi } 22 \text { Zi'l-hicce } \\
\text { sene } 1096 \text { Guruş-1 esedi } 5 \\
\text { Bâ-kefâlet-i İbrahim bin } \\
\text { Yakub 'an-mahalle-i Kepe } \\
\text { (Gebe) İlyas mezbûra dahi } \\
\text { ahâli-i mahallesi kefîldirler. }\end{array}$ \\
\hline $\begin{array}{l}\text { Mahalle-i Kalenderhâne } \\
\text { Agob veled-i Avanis'an- } \\
\text { mahalle-i EmirSultan } \\
\text { Bâ-kefâlet-i Markar veled-i } \\
\text { Ovanes 'an-mahalle-i } \\
\text { Hümame Sultan ve Şahin } \\
\text { veled-i Ohan 'an-mahalle-i } \\
\text { İslâm Paşa ve İsabiveled-i } \\
\text { Öge 'an-mahalle-i Hasbey } \\
\text { mezbûrlara dahi mahalleleri } \\
\text { ahâlisi kefîldirler. }\end{array}$ & $\begin{array}{l}\text { Mahalle-i Bağçıvân ma'a Tâç-1 } \\
\text { Kızıl ve gayrı } \\
\text { Hasan bin Süleyman'an-kazâ-i } \\
\text { Üçhisâr } \\
\text { Tezkire-dâde fi } 22 \text { Zi'l-hicce sene } \\
1096 \text { Guruş-1 esedi } 5 \\
\text { Bâ-kefâlet-i Bekir Bey ibn-i Abdi } \\
\text { 'an-mahalle-i mezbûr mezbûra dahi } \\
\text { mahalle ahâlisi kefîldirler. }\end{array}$ & \\
\hline
\end{tabular}




\begin{tabular}{|c|c|c|}
\hline \multicolumn{3}{|l|}{ Mahallât-ı Kefere } \\
\hline $\begin{array}{l}\text { Mahalle-i Hümame Sultan ma'a } \\
\text { Karkarlu } \\
\text { Şaban bin Himmet 'an- } \\
\text { mahalle-i Havâle } \\
\text { Tezkire-dâde fi } 22 \text { Zi'l-hicce } \\
\text { sene } 1096 \\
\text { Guruş-1 esedi } 5 \\
\text { Bâ-kefâlet-i Hüseyin } \\
\text { bin Osman'an-mahalle-i } \\
\text { m.mezbûra dahi mahalle ahâlisi } \\
\text { kefîldir. }\end{array}$ & $\begin{array}{l}\text { Mahalle-i Harbırit } \\
\text { Hızır bin Yusuf 'an-mahalle-i } \\
\text { Hasan Fakih } \\
\text { Tezkire-dâde fi } 22 \text { Zi'l-hicce } \\
\text { sene } 1096 \\
\text { Guruş-1 esedi } 5 \text { 'an-mahalle-i } \\
\text { Hasan Fakih } \\
\text { Bâ-kefâlet-i el-Hac Fethullah } \\
\text { bin Budak mezbûra dahi } \\
\text { mahalle ahâlisi kefîldirler. }\end{array}$ & \begin{tabular}{|l} 
Mahalle-i Rumiyân ma'a \\
Selaldı \\
Hızır veled-i Murad 'an- \\
mahalle-i Selaldı \\
Tezkire-dâde fi 22 Zi'l-hicce \\
sene 1096 \\
Guruş-1 esedi 5 \\
Agrez veled-i Haçidi \\
'an-mahalle-i mezbûr \\
Bâ-kefâlet-i Davud veled-i \\
Serkiz ve Kodil veled-i Yani \\
‥ ve Hoca Sultan veled-i \\
Yasef 'an-mahalle-i Sesliyân \\
mezbûrlara dahi mahalleleri \\
ahâlisi kefîldirler.
\end{tabular} \\
\hline
\end{tabular}

\section{[14]}

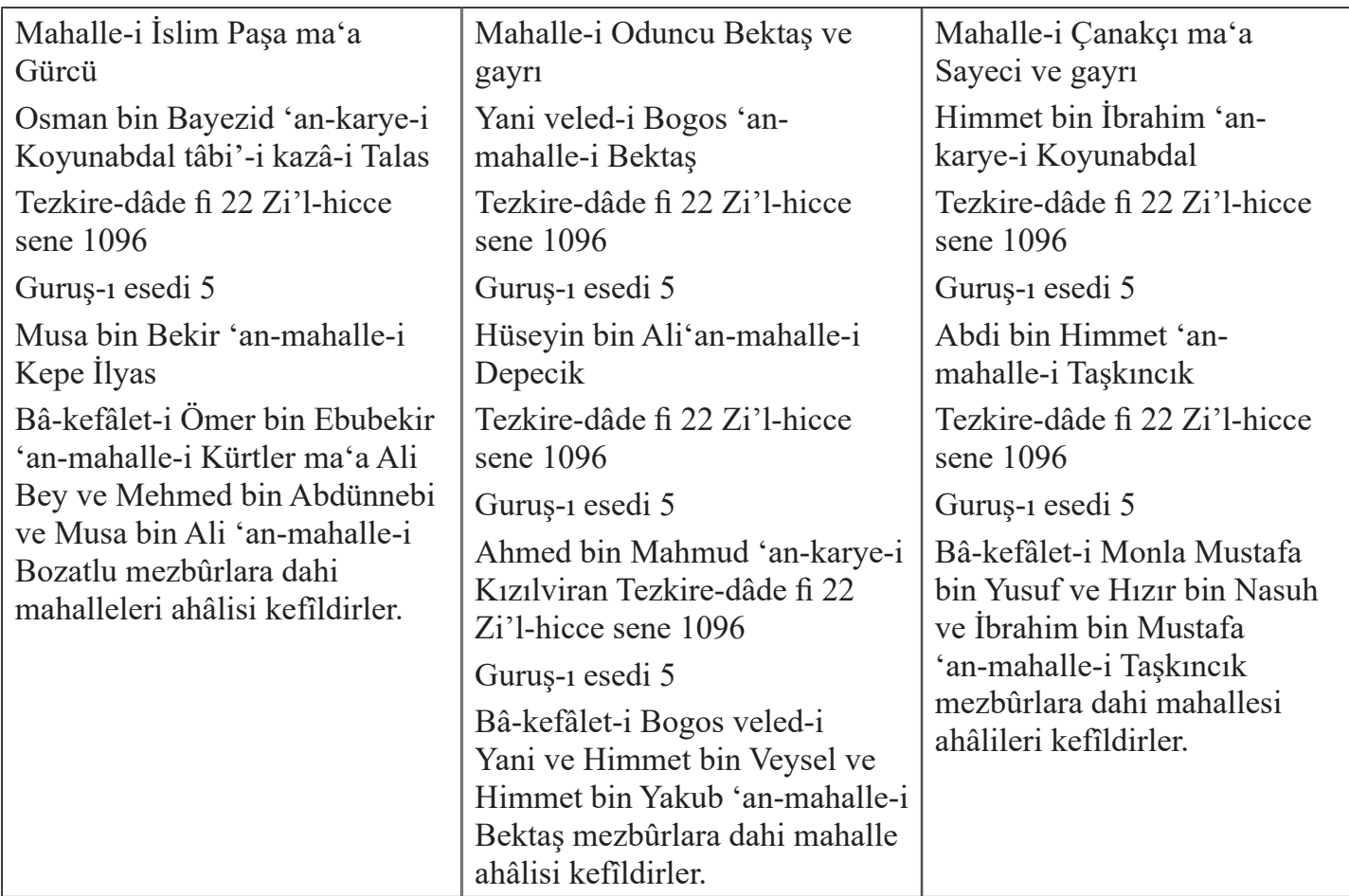




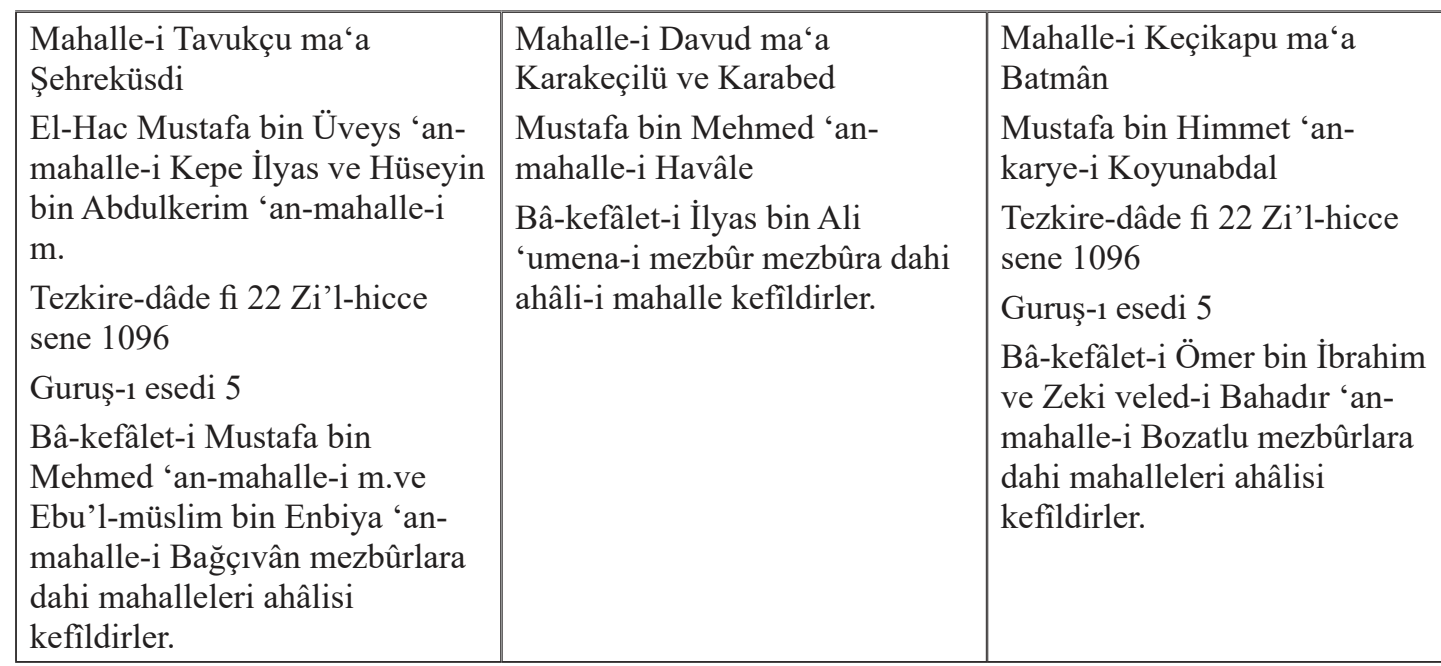

\begin{tabular}{|c|c|c|}
\hline \multicolumn{3}{|c|}{ Kurâ-yı sâire tâbi'-i kazâ-i Kayseri[yye] } \\
\hline $\begin{array}{l}\text { Karye-i Balages ma'a Kıranardı } \\
\text { ma'a Çırğalan } \\
\text { Veysel bin Hasan } \\
\text { 'an-mahalle-i Taşgıncık } \\
\text { Tezkire-dâde fi } 22 \text { Zi'l-hicce sene } \\
1096 \\
\text { Guruş-1 esedi } 5 \\
\text { Ömer bin Bayezid 'an-mahalle-i } \\
\text { Deliklitaş } \\
\text { Tezkire-dâde fi } 22 \text { Zi'l-hicce sene } \\
1096 \\
\text { Guruş-1 esedi } 5 \\
\text { Bâ-kefâlet-i Mustafa bin Budak } \\
\text { 'an-mahalle-i Eskisarây ve karye-i } \\
\text { mezbûrede Karabed veled-i } \\
\text { Bağos ve Deliklitaş mahallesinde } \\
\text { Sadık bin Ali kefîller olub } \\
\text { mezbûruna dahi karye-i mezbûr } \\
\text { ve mahalleleri ahâlileri kefillerdir. }\end{array}$ & $\begin{array}{l}\text { Karye-i Erkilet } \\
\text { Musa bin Hızır 'an } \\
\text { mahalle-i Gülek } \\
\text { Tezkire-dâde fi } 22 \\
\text { Zi'l-hicce sene } 1096 \\
\text { Guruş-1 esedi } 5 \\
\text { Mehmed bin el- } \\
\text { Hac Mustafa 'an- } \\
\text { mahalle-i Süleyman } \\
\text { Bâ-kefâlet-i } \\
\text { Abdülfettah bin } \\
\text { Halil 'an-mahalle-i } \\
\text { Gölek ve İbrahim } \\
\text { bin el-Hac Mustafa } \\
\text { 'an-mahalle-i } \\
\text { Süleyman ve } \\
\text { Abdünnebi bin } \\
\text { Cafer 'an-mahalle-i } \\
\text { mezbûr. } \\
\text { Mezbûrlara dahi } \\
\text { karye-i mezbûr ve } \\
\text { mahallât-1 mezbûr } \\
\text { ahâlileri kefîldirler. }\end{array}$ & $\begin{array}{l}\text { Karye-i Talâs } \\
\text { Yusuf bin Mehmed } \\
\text { 'an mahalle-i Musa Kâdı } \\
\text { Tezkire-dâde fi } 22 \text { Zi'l-hicce sene } 1096 \\
\text { Guruş-1 esedi } 5 \\
\text { Osman bin Ramazan 'an karye-i } \\
\text { Kızılvirân } \\
\text { Tezkire-dâde fi } 22 \text { Zi'l-hicce sene } 1096 \\
\text { Guruş-1 esedi } 5 \\
\text { Hasan bin Bektaş 'an-karye-i Kızılvirân } \\
\text { Tezkire-dâde fi } 22 \text { Zi'l-hicce sene } 1096 \\
\text { Guruş-1 esedi } 5 \\
\text { Halil bin Ramazan 'an-mahalle-i m. } \\
\text { Tezkire-dâde fi } 22 \text { Zi'l-hicce sene } 1096 \\
\text { Guruş-1 esedi } 5 \\
\text { Bâ-kefâlet-i es-Seyyid Ömer bin Seyyid } \\
\text { Abdülfettah 'an-mahalle-i Karakürkçü } \\
\text { ve Nasib bin Abdusselam 'an-mahalle-i } \\
\text { Mükremin ve Ali bin Ahmed 'an- } \\
\text { mahalle-i Tâçkıran ve Nasib bin } \\
\text { Abdussamed 'an-mahalle-i Hasan Fakih } \\
\text { mezbûrlara dahi kurâ ve mahalleleri } \\
\text { ahâlisi kefîldirler. }\end{array}$ \\
\hline
\end{tabular}




\begin{tabular}{|c|c|c|}
\hline $\begin{array}{l}\text { Karye-i Germeri } \\
\text { Mehmed bin Mustafa 'an- } \\
\text { mahalle-i Germelik } \\
\text { Tezkire-dâde fi } 22 \text { Zi'l-hicce sene } \\
1096 \\
\text { Guruş-1 esedi } 5 \\
\text { Mustafa veled-i Obur Mehmed } \\
\text { Tezkire-dâde fi } 22 \text { Zi'l-hicce sene } \\
1096 \\
\text { Guruş-1 esedi } 5 \\
\text { Mustafa bin Seydi 'an-karye-i } \\
\text { Kızlvirân } \\
\text { Bâ-kefâlet-i Seyyid Abdusselam } \\
\text { Çelebi ibn-i Hasan Bey ve } \\
\text { Ibrahim Bey ibn-i Mehmed 'an- } \\
\text { mahalle-i Huvând ve Seyyid } \\
\text { Ahmed bin Seyyid Himmet 'an- } \\
\text { mahalle-i Mükremin ve Seyyid } \\
\text { Mustafa Çelebi ibn-i Seyyid } \\
\text { Mehmed 'an-mahalle-i Şeyh } \\
\text { Taceddin mezbûrlara dahi karye-i } \\
\text { mezbûre ve mahallât-1 mezkûre } \\
\text { ahâlileri kefîldirler. } \\
\text { Karye-i Darsiyâk ma'a Demure } \\
\text { Abdurrahman Veli 'an-mahalle-i } \\
\text { Kethüdâ } \\
\text { Tezkire-dâde fi } 22 \text { Zi'l-hicce sene } \\
1096 \\
\text { Guruş-1 esedi } 5 \\
\text { Mustafa veled-i Abdurrahman } \\
\text { Tezkire-dâde fi } 22 \text { Zi'l-hicce sene } \\
\text { 1096 } \\
\text { Guruş-1 esedi } 5 \\
\text { Bâ-kefâlet-i Bekir Bey ibn-i Abdi } \\
\text { 'an-mahalle-i Bağçevân Battal bin } \\
\text { Ramazan 'an-mahalle-i Kethüdâ } \\
\text { mezbûrlar dahi karye-i mezbûr } \\
\text { ve mahalle-i mezkûr ahâlilleri } \\
\text { kefîldirler. }\end{array}$ & $\begin{array}{l}\text { Karye-i Çukur ma'a } \\
\text { Boyacalu } \\
\text { Ebubekir bin } \\
\text { Mustafa 'an- } \\
\text { mahalle-i Huvând } \\
\text { Tezkire-dâde fi } 22 \\
\text { Zi'l-hicce sene } 1096 \\
\text { Guruş-1 esedi } 5 \\
\text { Bâ-kefâlet-i Ahmed } \\
\text { bin Süleyman ve } \\
\text { Seyyid Abdusselam } \\
\text { Çelebi 'an- } \\
\text { mahalle-i Huvând } \\
\text { ve mezbûrlara dahi } \\
\text { karye-i mezbûr ve } \\
\text { mahalle-i mezbûr } \\
\text { ahâlileri kefîldirler. }\end{array}$ & $\begin{array}{l}\text { Karye-i Akgeren ma'a Hisârcık Hüseyin } \\
\text { bin Ömer 'an-karye-i Hisârcık guruş } 5 \\
\text { Halil bin Eyüb 'an-karye-i Kızılvirân } \\
\text { Tezkire-dâde fi } 22 \text { Zi'l-hicce sene } 1096 \\
\text { Guruş-1 esedi } 5 \\
\text { Yusuf bin Murad 'an-mahalle-i } \\
\text { Sarıürekli } \\
\text { Tezkire-dâde fi } 22 \text { Zi'l-hicce sene } 1096 \\
\text { Guruş-1 esedi } 5 \\
\text { Adanis bin Himmet 'an-mahalle-i } \\
\text { Huvând } \\
\text { Tezkire-dâde fi } 22 \text { Zi'l-hicce sene } 1096 \\
\text { Guruş-1 esedi } 5 \\
\text { Bâ-kefâlet-i Mustafa bin Ömer 'an- } \\
\text { karye-i Akkere ve Seyyid Halil Efendi } \\
\text { ibn-i Seyyid Ali ve Ömer bin Himmet } \\
\text { ve Ali Kethüdâ 'an-mahalle-i Şeyh } \\
\text { Taceddin mezbûrlara dahi kurâ ve } \\
\text { mahallât-1 mezbûr ahalileri kefildirler }\end{array}$ \\
\hline
\end{tabular}




\begin{tabular}{|c|c|c|c|}
\hline $\begin{array}{l}\text { Karye-i Erdürlük ma'a Akçakaya } \\
\text { ma'a Koz Cafer } \\
\text { Ali bin Ebu'l-Kasım'an-mahalle-i } \\
\text { Bozatlu } \\
\text { Tezkire-dâde fi } 22 \text { Zi'l-hicce sene } \\
1096 \\
\text { Guruş-1 esedi } 5 \\
\text { Ahmed bin Ali 'an-mahalle-i } \\
\text { Taşkıncık } \\
\text { Tezkire-dâde fi } 22 \text { Zi'l-hicce sene } \\
1096 \\
\text { Guruş-1 esedi } 5 \\
\text { Bâ-kefâlet-i Mehmed bin } \\
\text { Süleyman 'an-mahalle-i Bağçevân } \\
\text { ve Mustafa bin Mahmud 'an- } \\
\text { mahalle-i Taşkıncık mezbûrlara } \\
\text { dahi karye-i mezbûr ve mahallât-1 } \\
\text { mezkûr ahâlileri kefîldirler. }\end{array}$ & $\begin{array}{l}\text { Karye-i Mancusun } \\
\text { ma'a Yorgan ma'a } \\
\text { Alagöz ve gayrı } \\
\text { Durak bin Mustafa } \\
\text { 'an-mahalle-i } \\
\text { Koyunabdâl } \\
\text { Cafer bin Durak 'an- } \\
\text { mahalle-i mezbûr } \\
\text { Tezkire-dâde fi } 22 \\
\text { Zi'l-hicce sene } 1096 \\
\text { Guruş-1 esedi } 5 \\
\text { Bâ-kefâlet-i Çelebi } \\
\text { bin Ebu'l-Kasım ve } \\
\text { İsmail bin Çelebi } \\
\text { 'an-mahalle-i } \\
\text { Hasbey ve Ali bin } \\
\text { Hasan ve Ahmed bin } \\
\text { İdris 'an-mahalle-i } \\
\text { Huvând mezbûrlara } \\
\text { dahi karye-i } \\
\text { mezbûrve mahalle-i } \\
\text { mezkûre ahâlileri } \\
\text { kefîldirler. }\end{array}$ & $\begin{array}{l}\text { Karye-i Berid } \\
\text { Üveys bin } \\
\text { Ahmed 'an- } \\
\text { mahalle-i } \\
\text { Mükremin } \\
\text { Tezkire-dâde } \\
\text { fi } 22 \text { Zi'l-hicce } \\
\text { sene } 1096 \\
\text { Guruş-1 esedi } 5 \\
\text { Bâ-kefâlet-i } \\
\text { Ahmed bin } \\
\text { Üveys Pedereş } \\
\text { mezbûra } \\
\text { dahi karye } \\
\text { ve mahalle-i } \\
\text { mezbûre ahâlisi } \\
\text { kefîldirler. }\end{array}$ & $\begin{array}{l}\text { Karye-i Kızılvirân } \\
\text { Mehmed bin Ahmed } \\
\text { 'an-karye-i m. } \\
\text { Tezkire-dâde fi } 22 \\
\text { Zi'l-hicce sene } 1096 \\
\text { Guruş-1 esedi } 5 \\
\text { Bâ-kefâlet-i İbrahim } \\
\text { bin Şaban ve Veli } \\
\text { bin Musa 'an- } \\
\text { karye-i mezbûr } \\
\text { mezbûrlara dahi } \\
\text { karye-i mezbûr } \\
\text { ahâlisi kefîldirler. }\end{array}$ \\
\hline
\end{tabular}

\section{[15]}

\begin{tabular}{|c|c|c|}
\hline $\begin{array}{l}\text { Karye-i Venk } \\
\text { İbrahim veled-i As(v)adur }\end{array}$ & $\begin{array}{l}\text { Karye-i Tevânesun ma'a Oyu- } \\
\text { mağaç ma'a Keykubâd ma'a } \\
\text { Surunca ma'a Anbarlu } \\
\text { Kasım bin Hasan 'an-mahalle-i } \\
\text { Seydiyar Gazi } \\
\text { Tezkire-dâde fi } 22 \text { Zi'l-hicce } \\
\text { sene } 1096 \\
\text { Guruş-1 esedi } 5 \\
\text { İbrahim bin Şahin bin Şahin } \\
\text { 'an-mahalle-i m. } \\
\text { Tezkire-dâde fi } 22 \text { Zi'l-hicce } \\
\text { sene } 1096 \\
\text { Guruş-1 esedi } 5 \\
\text { Bâ-kefâlet-i Hüseyin bin Hasan } \\
\text { diğer Hüseyin bin Hasan } \\
\text { 'an-karye-i m. Mezbûrlara dahi } \\
\text { mahalle ahâlisi kefîldirler. }\end{array}$ & $\begin{array}{l}\text { Karye-i Zincidere ma‘a Yasablu } \\
\text { ma‘a Sombekir ma‘a Tantal } \\
\text { ma‘a Kamane } \\
\text { Mehmed bin Ali 'an-mahalle-i } \\
\text { Bağçevân } \\
\text { Tezkire-dâde fi } 22 \text { Zi'l-hicce } \\
\text { sene } 1096 \\
\text { Guruş-1 esedi } 5 \\
\text { Bâ-kefâlet-i Süleyman Ömer } \\
\text { 'an-mahalle-i m. Mezbûra dahi } \\
\text { mahalle ve karye-i mezbûre } \\
\text { ahâlisi kefîldir. }\end{array}$ \\
\hline
\end{tabular}




\begin{tabular}{|c|c|c|}
\hline $\begin{array}{l}\text { Karye-i Curlavik } \\
\text { Musa bin Hasan 'an-mahalle-i } \\
\text { Hasbey } \\
\text { Tezkire-dâde fi } 22 \text { Zi'l-hicce } \\
\text { sene } 1096 \\
\text { Guruş-1 esedi } 5 \\
\text { Bâ-kefâlet-i Mahmud bin } \\
\text { İbrahim'an-mahalle-i m. Mez- } \\
\text { bûra dahi karye-i mezbûr ahâli- } \\
\text { si kefîldirler. }\end{array}$ & $\begin{array}{l}\text { Karye-i Vekse ma'a Tiravesin } \\
\text { ma'a Kömür ma'a Güni } \\
\text { İdris bin Davud 'an-karye-i } \\
\text { Kızılvirân } \\
\text { Bâ-kefâlet-i Ali bin el-Hac } \\
\text { Abdussabah 'an-mahalle-i } \\
\text { Karakürkçü mezbûra dahi ahâ- } \\
\text { li-i mahalle kefîldirler. }\end{array}$ & $\begin{array}{l}\text { Karye-i Kızpire ma'a Dadağı } \\
\text { ma'a İnce ma'a Sokson ve gayrı } \\
\text { Mustafa bin Ali 'an-mahalle-i } \\
\text { Kürtler } \\
\text { Tezkire-dâde fi } 22 \text { Zi'l-hicce } \\
\text { sene } 1096 \\
\text { Guruş-1 esedi } 5 \\
\text { Bâ-kefâlet-i Hasan bin Yusuf } \\
\text { 'an-mahalle-i Kürtler ve Seyy- } \\
\text { id Fethullah bin Seyyid Salih } \\
\text { mezbûrlara dahi mahalle ahâlisi } \\
\text { kefîldirler. }\end{array}$ \\
\hline $\begin{array}{l}\text { Karye-i Salur ma'a Tatasun } \\
\text { ma'a Yersam ve gayrı } \\
\text { Hüseyin bin Ömer 'an-karye-i } \\
\text { Tatasun } \\
\text { Tezkire-dâde fi } 22 \text { Zi'l-hicce } \\
\text { sene } 1096 \\
\text { Guruş-1 esedi } 5 \\
\text { Bâ-kefâlet-i Seyyid Ali bin İdris } \\
\text { ve Çelebi bin Ali 'an-karye-i } \\
\text { mezbûr. } \\
\text { Mezbûra dahi karyeleri ahâlisi } \\
\text { kefîldirler. }\end{array}$ & $\begin{array}{l}\text { Karye-i Kızıkma'a Saraycık } \\
\text { ma‘a Oyumağaç ve gayrı } \\
\text { Ebubekir bin Ali 'an-mahalle-i } \\
\text { Kürtler } \\
\text { Tezkire-dâde fi } 22 \text { Zi'l-hicce } \\
\text { sene } 1096 \text { Guruş-1 esedi } 5 \\
\text { Bâ-kefâlet-i Mustafa bin } \\
\text { Durmuş ve Musli bin Nasuh } \\
\text { 'an-karye-i mezbûr. Mezbûrlara } \\
\text { dahi karye-i mezbûre ahâlisi } \\
\text { kefîldirler. }\end{array}$ & $\begin{array}{l}\text { Karye-i Ağırbaş ma'a Üskübi } \\
\text { Nikola veled-i Çoban } \\
\text { Tezkire-dâde fi } 22 \text { Zi'l-hicce } \\
\text { sene } 1096 \\
\text { Guruş-1 esedi } 5 \\
\text { Bâ-kefâlet-i Vasil veled-i Sare } \\
\text { mezbûra dahi karye-i mezbûr } \\
\text { ahâlisi kefîldirler. }\end{array}$ \\
\hline
\end{tabular}

'An-cânib-i livâ-i Alâcahisâr

Mübaşir Şaban Çavuş

Beldâran Neferan 20

\begin{tabular}{|l|l|l|l|}
\hline $\begin{array}{l}\text { Kazâ-i Alâcahisâr } \\
\text { Neferan: 5 }\end{array}$ & $\begin{array}{l}\text { Vode veled-i } \\
\text { Bogdan }\end{array}$ \\
\hline Uzun Mustafa & Hasan bin Osman & $\begin{array}{l}\text { Diğer Mustafa bin } \\
\text { Ahmed }\end{array}$ & Receb bin Veli \\
\hline
\end{tabular}

\begin{tabular}{|c|c|c|c|c|}
\hline \multicolumn{5}{|l|}{$\begin{array}{l}\text { Kazâ-i Leskofça } \\
\text { Neferan: } 14\end{array}$} \\
\hline $\begin{array}{l}\text { Receb bin Abdu- } \\
\text { rrahman } \\
\text { Ser-beldâran } \\
\text { Bâ-kefâlet-i } \\
\text { Mehmed Ağa ve } \\
\text { Dede Mehmed } \\
\text { Bey ve Durmuş } \\
\text { Sipâhi }\end{array}$ & $\begin{array}{l}\text { Ebubekir bin } \\
\text { Ahmed } \\
\text { Bâ-kefâlet-i } \\
\text { mübâşir-i beldâr }\end{array}$ & $\begin{array}{l}\text { Ahmed bin Ab- } \\
\text { dullah } \\
\text { Bâ-kefâlet-i İbra- } \\
\text { him Çelebi }\end{array}$ & $\begin{array}{l}\text { Haydar bin Hasan } \\
\text { Bâ-kefâlet-i } \\
\text { mübâşir-i beldâr }\end{array}$ & $\begin{array}{l}\text { Yusuf bin Ali } \\
\text { Bâ-kefâlet-i Dede } \\
\text { Mehmed Bey }\end{array}$ \\
\hline
\end{tabular}




\begin{tabular}{|l|l|l|l||l|}
\hline Ahmed bin & Mehmed bin Ali & Abdülkadir ibn-i & Mehmed bin Ab- & Süleyman bin \\
Mehmed & Bâ-kefâlet-i & Ahmed & dullah & Ahmed \\
Bâ-kefâlet-i Pap- & mübâşir-i beldâr & Bâ-kefâlet-i & Bâ-kefâlet-i & Bâ-kefâlet-i \\
uççu Mehmed & & mübâş̧ir-i beldâr & Kayrabaş1 Kamir & mübâşir-i beldâr \\
\hline
\end{tabular}

[16]

\begin{tabular}{|c|c|c|c|}
\hline $\begin{array}{l}\text { Zülfikar bin Ali 'an-kar- } \\
\text { ye-i Pertate } \\
\text { Bâ-kefâlet-i Durmuş } \\
\text { bin (boş) }\end{array}$ & $\begin{array}{l}\text { Hasan bin Ali } \\
\text { Bâ-kefâlet-i ...imâmı } \\
\text { Kanber }\end{array}$ & $\begin{array}{l}\text { Yovan veled-i Radosav } \\
\text { 'an-karye-i Sinkofça } \\
\text { Bâ-kefâlet-i Mehmed } \\
\text { Bey }\end{array}$ & $\begin{array}{l}\text { Mirça veled-i Deyo } \\
\text { 'an-karye-i Zaplan } \\
\text { Bâ-kefâlet-i Ekmekçi } \\
\text { Hasan }\end{array}$ \\
\hline
\end{tabular}

\section{Kazâ-i Ürgüb tâbi'-i Alâcahisâr}

Güro veled-i Petro 'an-karye-i Çaynofça

Yekûn livâ-i Alâcahisâr

Beldâran Neferan: 20

'An-cânib-i Üsküb

Lağımciyân Neferan: 75

Kazâ-i Üsküb Neferan: 30

\section{[17]}

Kazâ-i Kratova Neferan: 23

[18]

Kazâ-i Kalkandelen der-livâ-i Üsküb Neferan: 10

Kazâ-i Köprülü Neferan: 12

Kazâ-i İvrânye Neferan: 10

\begin{tabular}{|l|l|l|l|l|}
\hline $\begin{array}{l}\text { Kenan bin } \\
\text { Abdullah } \\
\text { sâkin-i kasaba }\end{array}$ & $\begin{array}{l}\text { İbrahim bin } \\
\text { Abdullah } \\
\text { sâkin-i m. }\end{array}$ & Hasan bin Ridvan & Ahmed bin Sefer & İbrahim bin Halil \\
\hline Ali bin Abdullah & $\begin{array}{l}\text { Ahmed bin } \\
\text { Abdurrahman }\end{array}$ & $\begin{array}{l}\text { Mustafa bin } \\
\text { Hasan }\end{array}$ & $\begin{array}{l}\text { Mustafa bin } \\
\text { Abdurrahman }\end{array}$ & $\begin{array}{l}\text { Mahmud bin } \\
\text { Mehmed }\end{array}$ \\
\hline
\end{tabular}


[19]

Defter oldur ki Estergon muhâfazasında me'mûr olan neccâr kullarıdır ki divân tezkireleri vardır.

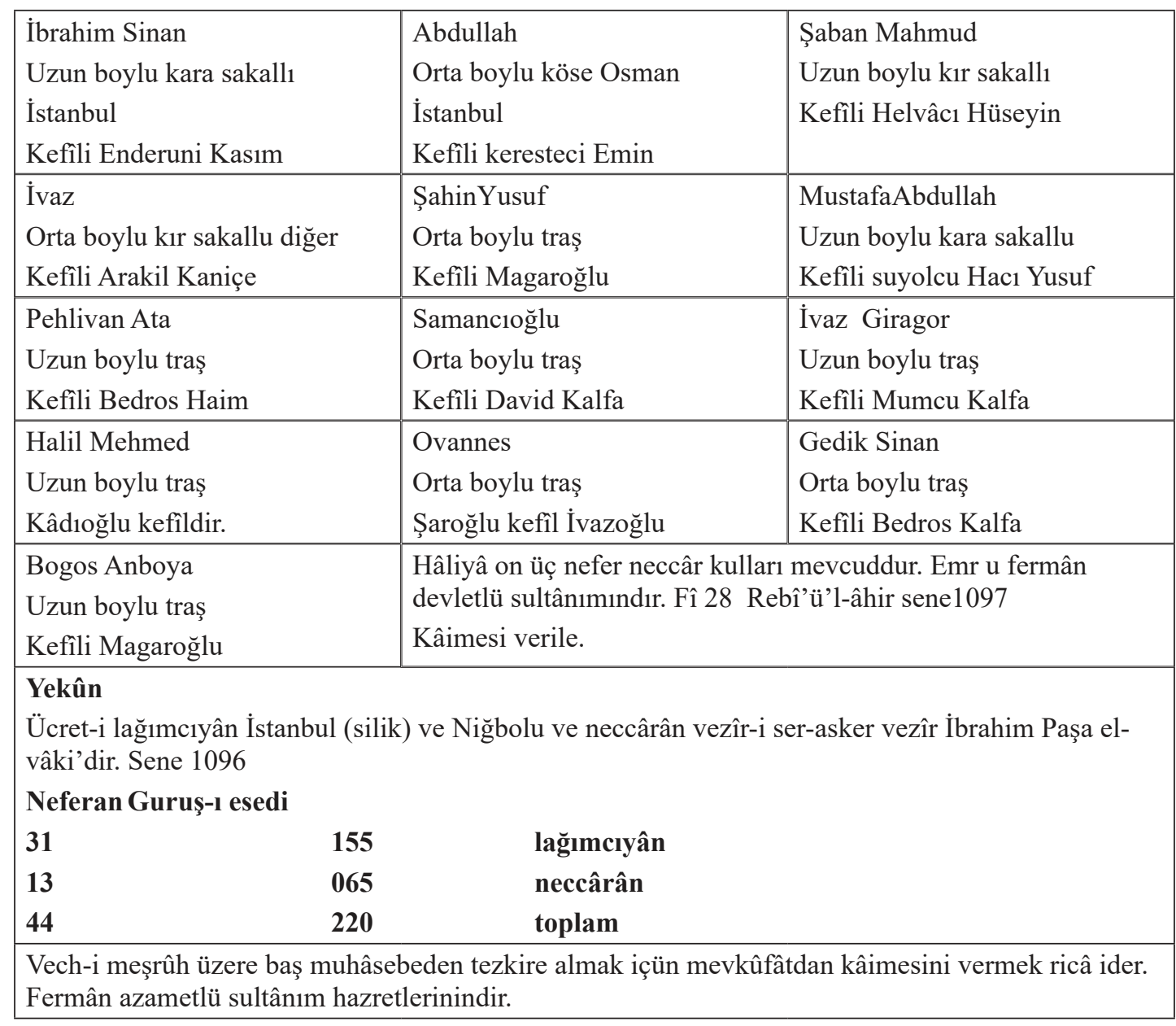

[22]

Sahh

İzzetlü Defterdâr Efendi

Derûn-1 defterde mestûr olan otuz beş nefer lağımcı ve on üç nefer neccâr tarafina verilmekden beşer gurûş kayd şod. Gurre-i Ra 97

Defter oldur ki Estergon muhâfazasında me'mûr olan lağımcılara bâ-tezkire-i divan 


\begin{tabular}{|c|c|c|}
\hline $\begin{array}{l}\text { Teğagos Serkis } \\
\text { İstanbul } \\
\text { Yüzü traşlı }\end{array}$ & $\begin{array}{l}\text { Kirkor Haçok } \\
\text { İstanbul } \\
\text { Uzun boylu kırçıl sakallı }\end{array}$ & $\begin{array}{l}\text { Murad Kostontor } \\
\text { İstanbul } \\
\text { Uzun boylu kara sakallı }\end{array}$ \\
\hline $\begin{array}{l}\text { Hüseyin Musa } \\
\text { İstanbul } \\
\text { Uzun boylu traş }\end{array}$ & $\begin{array}{l}\text { Murad Karaca } \\
\text { İstanbul } \\
\text { Uzun boylu kırçıl sakallı }\end{array}$ & $\begin{array}{l}\text { Nikola Çoban } \\
\text { Kayseri } \\
\text { Uzun boylu kara sakallı }\end{array}$ \\
\hline $\begin{array}{l}\text { Bali Kara Hoca } \\
\text { İstanbul } \\
\text { Uzun boylu kır sakallı }\end{array}$ & $\begin{array}{l}\text { HaçokVartan } \\
\text { İstanbul } \\
\text { Uzun boylu traş }\end{array}$ & $\begin{array}{l}\text { Avcı Sefer } \\
\text { İstanbul } \\
\text { Uzun boylu kara sakallı }\end{array}$ \\
\hline $\begin{array}{l}\text { İvaz Abdullah } \\
\text { İstanbul } \\
\text { Orta boylu traş }\end{array}$ & $\begin{array}{l}\text { Osman Ahmed } \\
\text { İstanbul } \\
\text { Orta boylu taze oğlan }\end{array}$ & $\begin{array}{l}\text { Cengioğlu ser-bölük } \\
\text { İstanbul } \\
\text { Uzun boylu sakallı }\end{array}$ \\
\hline $\begin{array}{l}\text { Hasan Süleyman } \\
\text { Kayseri } \\
\text { Orta boylu kumral sakallı }\end{array}$ & $\begin{array}{l}\text { Bekir Hasan } \\
\text { İstanbul } \\
\text { Uzun boylu kırçıl sakallı }\end{array}$ & $\begin{array}{l}\text { Mustafa Mehmed } \\
\text { Kayseri } \\
\text { Uzun boylu kır sakallı }\end{array}$ \\
\hline $\begin{array}{l}\text { Karabed Murad } \\
\text { İstanbul } \\
\text { Uzun boylu traş }\end{array}$ & $\begin{array}{l}\text { Mehmed Ali } \\
\text { Kayseri } \\
\text { Uzun boylu kara sakallı }\end{array}$ & $\begin{array}{l}\text { Ahyar Serkis } \\
\text { İstanbul } \\
\text { Orta boylu kır sakallı }\end{array}$ \\
\hline $\begin{array}{l}\text { Serkis Babof } \\
\text { İstanbul } \\
\text { Orta boylu traş }\end{array}$ & $\begin{array}{l}\text { Bağvan Karabed } \\
\text { İstanbul } \\
\text { Uzun boylu traş }\end{array}$ & $\begin{array}{l}\text { İsayi Markar } \\
\text { İstanbul } \\
\text { Uzun boylu traş }\end{array}$ \\
\hline $\begin{array}{l}\text { Hüsrev Yusuf } \\
\text { İstanbul } \\
\text { Kara sakallı }\end{array}$ & $\begin{array}{l}\text { Toros Henkik } \\
\text { İstanbul } \\
\text { Uzun boylu kara sakallı }\end{array}$ & $\begin{array}{l}\text { Serkis Henkik } \\
\text { İstanbul } \\
\text { Orta boylu kara sakallı }\end{array}$ \\
\hline $\begin{array}{l}\text { ŞabanYusuf } \\
\text { Niğde } \\
\text { Orta boylu sarı sakallı }\end{array}$ & $\begin{array}{l}\text { Hüseyin Ali } \\
\text { İstanbul } \\
\text { Uzun boylu traş }\end{array}$ & $\begin{array}{l}\text { İbrahimAli } \\
\text { İstanbul } \\
\text { Uzun boylu kaba sakallı }\end{array}$ \\
\hline $\begin{array}{l}\text { Ahmed Ramazan } \\
\text { İstanbul } \\
\text { Orta boylu kara sakallı }\end{array}$ & $\begin{array}{l}\text { Serkis Nor } \\
\text { İstanbul } \\
\text { Orta boylu kara sakallı }\end{array}$ & $\begin{array}{l}\text { Şahin Sefer } \\
\text { İstanbul } \\
\text { Orta boylu traş }\end{array}$ \\
\hline $\begin{array}{l}\text { Haçadur } \\
\text { İstanbul } \\
\text { Orta boylu traş }\end{array}$ & & \\
\hline
\end{tabular}

İmzalısı zâyi’ olmuş

Hâliyâ otuz bir nefer kulları mevcuddur. Emr u fermân devletlü sultânımındır.

\section{[23]}

Kazâ-i Samakov Neferan: 40 
[24]

'An-cânib-i Biga

BeldâranNeferan: 60

Kazâ-i Biga

Kazâ-i Güvercinlik Neferan: 3

Kazâ-i Lapseki Neferan: 7

Kazâ-i Kal'a-i Sultâniye Neferan: 3

Kazâ-i Eynebazâr1 Neferan: 12

\section{Sonuç}

Çalışmaya konu olan defter, Osmanlı Devleti'nin II. Viyana bozgunundan sona Avusturya cephesinde giriştiği mücadelelerin bir kesitine dair bilgiler içermektedir. Bilindiği üzere Merzifonlu Kara Mustafa Paşa'nın yerine sadrazamlığa getirilen Kara İbrahim Paşa, hastalığını bahane etmiş ve cepheye gitmeyerek serdarlar göndermeyi tercih etmişti. Bu süreçte Budin savunmasındaki başarılarından adı ön plana çıkan İbrahim Paşa (Şeytan/Melek), Macaristan seraskerliğine atanmıştı. İbrahim Paşa, Estergon'u almak için bir kuşatma planlamışsa da başarılı olamamış bu arada Uyvar da düşmüştü. Bu başarısızlıklar İbrahim Paşa’ya karşı olan kişiler için firsat doğurmuş, bu kişilerin etkisiyle idamına karar verilmişti. İbrahim Paşa'nın, Macaristan seraskerliği yaptığı süreçte düzenlenen ve çalışmaya konu olan defterde dikkat çeken bir husus defterdeki bazı tarihlerin İbrahim Paşa'nın idamından (6 Muharrem 1097/3 Aralık 1685) sonraki döneme denk gelmesidir. Ancak bu kısımlarda kullanılan Ser-asker ve vezîr-i mükerrem İbrahim Paşa ifadesi tarihleme konusunda katibin yanlışlık yaptığ 1 ihtimalini akla getirmektedir.

Engürüs Seferi ve Estergon muhafazasına 379 lağımcı, 308 beldar ve 48 neccar katılmıştı. Bu hizmet birlikleri İstanbul, Kayseri, Edirne, Manastır, Niğde, Alacahisar, Leskofça, Ürgüb, Üsküb, Katova, Kalkandelen, Köprülü, İvranye, Samokov, Biga, Güvercinlik, Lapseki, Sultaniye ve Eynebazarı yöre ve kazalarından temin edilmişti. Hem Anadolu hem de Rumeli kazalarından temin edilen bu kişiler arasında Müslim-gayrimüslim ayrımı yapılmamış olması Osmanlı askeri teşkilatı içerisinde farklı din ve etnikten kişilerin varlığını teyit etmektedir. Ayrıca deftere kaydedilen belderan ve lağımcılara bazen bir bazen birden fazla kişinin bazen de köy ahalisinin hepsinin kefil olması bu gurupların temininde seçilen kişilerin güvenirliğinin önemsendiğini göstermektedir. 


\section{KAYNAKLAR}

\section{Kaynak Eserler}

Defterdar Sarı Mehmed Paşa, Zübde-i Vekayiât Tahlil ve Metin (1066-1116/1656-1704), (Haz. Abdülkadir Özcan), Türk Tarih Kurumu, Ankara 1995.

Mustafa Nuri Paşa, Netâyic ül-Vukuat, (Sad. Neşet Çağatay), I-II, Türk Tarih Kurumu Bas1mevi, Ankara 1992.

Râşid Mehmed, Târih-i Râş̧id, I, İstanbul 1865.

Şemseddin Sami, Kâmûs al-a lâm, Mihran Matbaası, İstanbul 1306.

Silahdâr Findıkl11ı Mehmed Ağa, Silâhdâr Târîhi, I. Cild (1065-1094), İstanbul Devlet Matbaas1, 1928.

Silahdâr Fındıklılı Mehmed Ağa, Silâhdâr Târîhi, II. Cild, İstanbul Orhaniye Matbaası, 1928.

\section{Araştırma ve İnceleme Eserler}

Cezar, Mustafa, Mufassal Osmanlı Tarihi Resimli-Haritalı, C IV, Türk Tarih Kurumu Yayınlar1, Ankara 2011.

Çiçek, Kemal, “II. Viyana Kuşatması ve Avrupa'dan Dönüş (1683-1703)”, Türkler, C IX, Ankara 2002, s. 746-761.

Göger, Veysel, 16. Yüzyıl Kale Kuşatmaları (Stratejik, Taktik, Kuşatma Aşamaları ve Teknolojisi), Marmara Üniversitesi Sosyal Bilimler Enstitüsü Türkiyat Araştırmaları Enstitüsü Türk Tarihi Anabilim Dalı Yeniçağ Tarihi Anabilim Dalı, Yayımlanmamış Doktora Tezi, İstanbul 2014.

İnbaş1, Mehmet, Ukrayna'da Osmanlılar Kamaniçe Seferi ve Organizasyonu (1672), Yeditepe Yayınları, İstanbul 2004.

Kaçan Erdoğan, Meryem, II. Viyana Kuşatması, Marmara Üniversitesi Sosyal Bilimler Enstitüsü Türkiyat Araştırmaları Enstitüsü Türk Tarihi Anabilim Dalı Yeniçağ Tarihi Anabilim Dalı, Yayımlanmamış Doktora Tezi, İstanbul 2001.

Kantemir, Dimitri, Osmanlı Imparatorluğunun Yükseliş ve Çöküş Tarihi, III, (Çev. Dr. Özdemir Çobanoğlu), Kültür Bakanlığg Yayınları, Ankara 1980.

Özcan, Abdülkadir, “İbrahim Paşa, Kara”, DİA, C XXI, İstanbul 2000, s. 329-330.

Özcan, Abdülkadir, “İbrahim Paşa, Melek”, DİA, C XXI, İstanbul 2000, s. 335-337.

Özcan, Abdülkadir, "Lağımcı Ocağı”, DİA, C XXVII, Ankara 2003, s. 49-50.

Özcan, Abdülkadir, "Mehmed IV”, DİA, C XXVIII, İstanbul 2000, s. 414-418. 
Özcan, Abdülkadir, “Osmanlı Askeri Teşkilatı”, Osmanlı VI, (Ed. Güler Eren), Yeni Türkiye Yayınları, Ankara 1999, s. 551-557.

Özger, Yunus, “Sadrazam Kara İbrahim Paşa Vakıfları”, Tarih İncelemeleri Dergisi, C XXIII/S. 2 (Aralık 2008), s. 109-150.

Pakalın, M. Zeki, Osmanlı Tarih Değimleri ve Terimleri Sözlü̆̆̈̈, I, Milli Eğitim Basımevi, İstanbul 1983.

Pakalın, M. Zeki, Osmanlı Tarih Değimleri ve Terimleri Sözlüğü, II, Milli Eğitim Basımevi, İstanbul 1983.

Parmaksızoğlu, İsmet, “İbrahim Paşa, Kara İbrahim Paşa”, İslam Ansiklopedisi, C V/II, Milli Eğitim Basımevi, İstanbul 1968, s. 906-908.

Sertoğlu, Midhat, Osmanlı Tarih Lûgatı, Enderun Kitabevi, İstanbul 1986.

Sevinç, Tahir, 1695 ve 1696 Avusturya Seferlerinde Organizasyon ve Lojistik, Marmara Üniversitesi Sosyal Bilimler Enstitüsü Türkiyat Araştırmaları Enstitüsü Türk Tarihi Anabilim Dalı Yeniçağ Tarihi Anabilim Dalı, Yayımlanmamış Doktora Tezi, İstanbul 2010.

Şimşirgil, Ahmet, Kayı VI Osmanlı Tarihi Imparatorluğun Zirvesi ve Dönüş, Timaş Yayınları, İstanbul 2014.

Taib Ahmed Osmanzade, Hadikatü'l Vüzera, Ceride-i Havadis Matbaası, İstanbul 1271.

Üçel-Aybet, Gülgün, Avrupalı Seyyahların Gözüyle Osmanlı Ordusu (1530-1699), İletişi̇m Yayınc1lik, İstanbul 2010.

Uzunçarşı11, İsmail Hakkı, Kapıkulu Ocakları, II, Türk Tarih Kurumu Yayınları, Ankara 1984. 
DEFTER

\section{MALIYEDEN MÜDEVVER DEFTER}

MAD.d

\section{DEFTER NO: 07723}


Engürüs Seferi ve Estergon Muhafazasına Katılan Geri Hizmet Birliklerine Ait 1685 Tarihli Defter

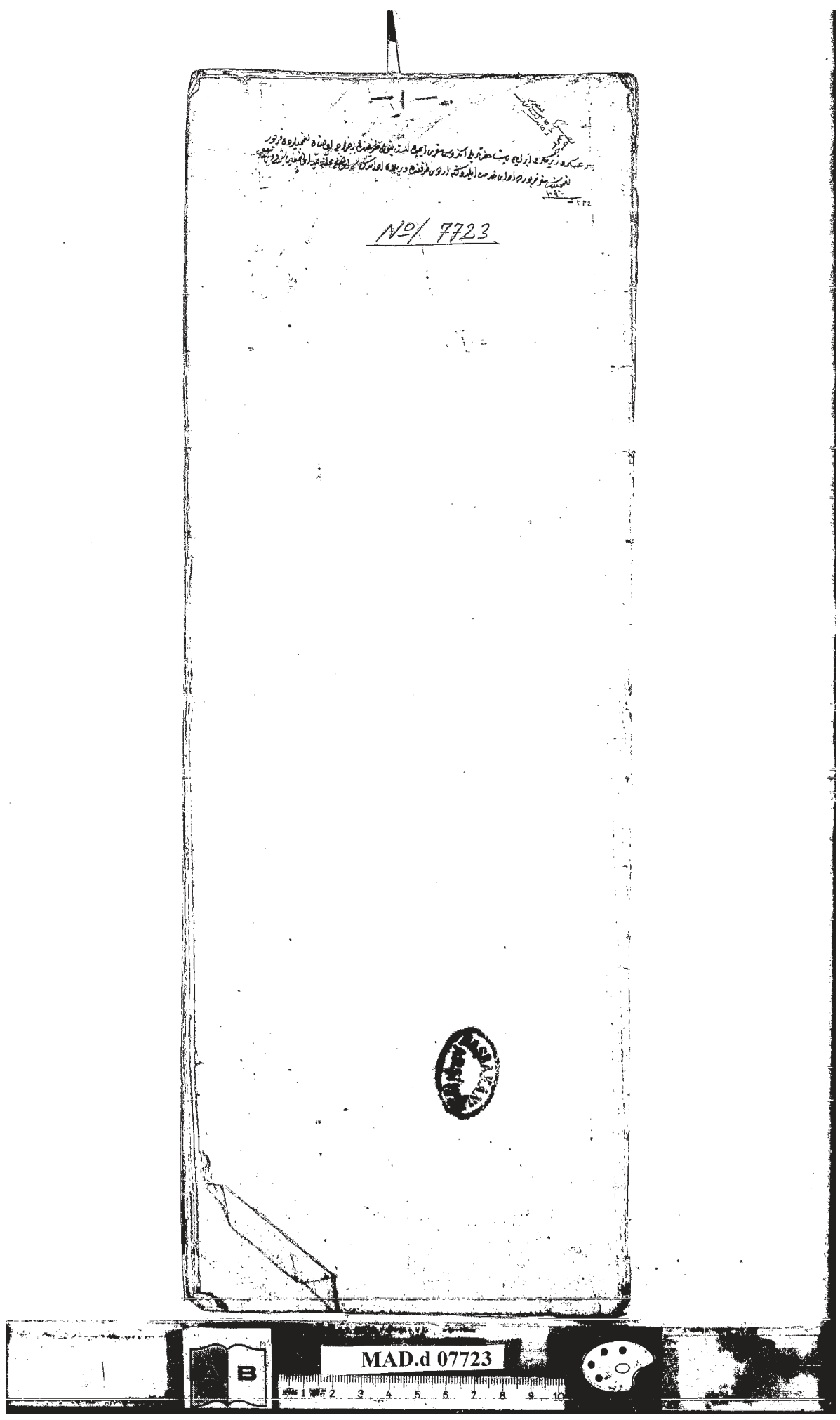




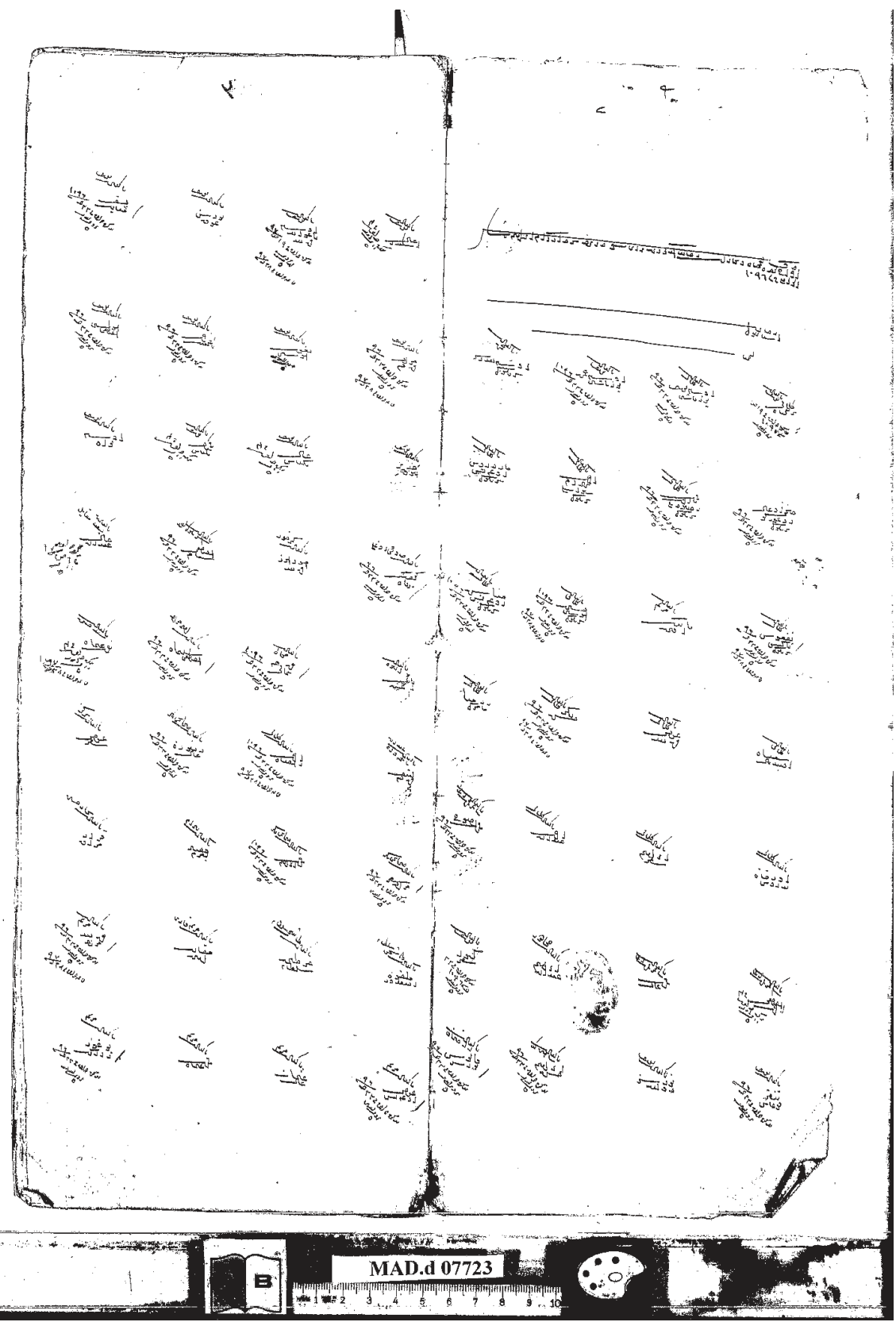


Engürüs Seferi ve Estergon Muhafazasına Katılan Geri Hizmet Birliklerine Ait

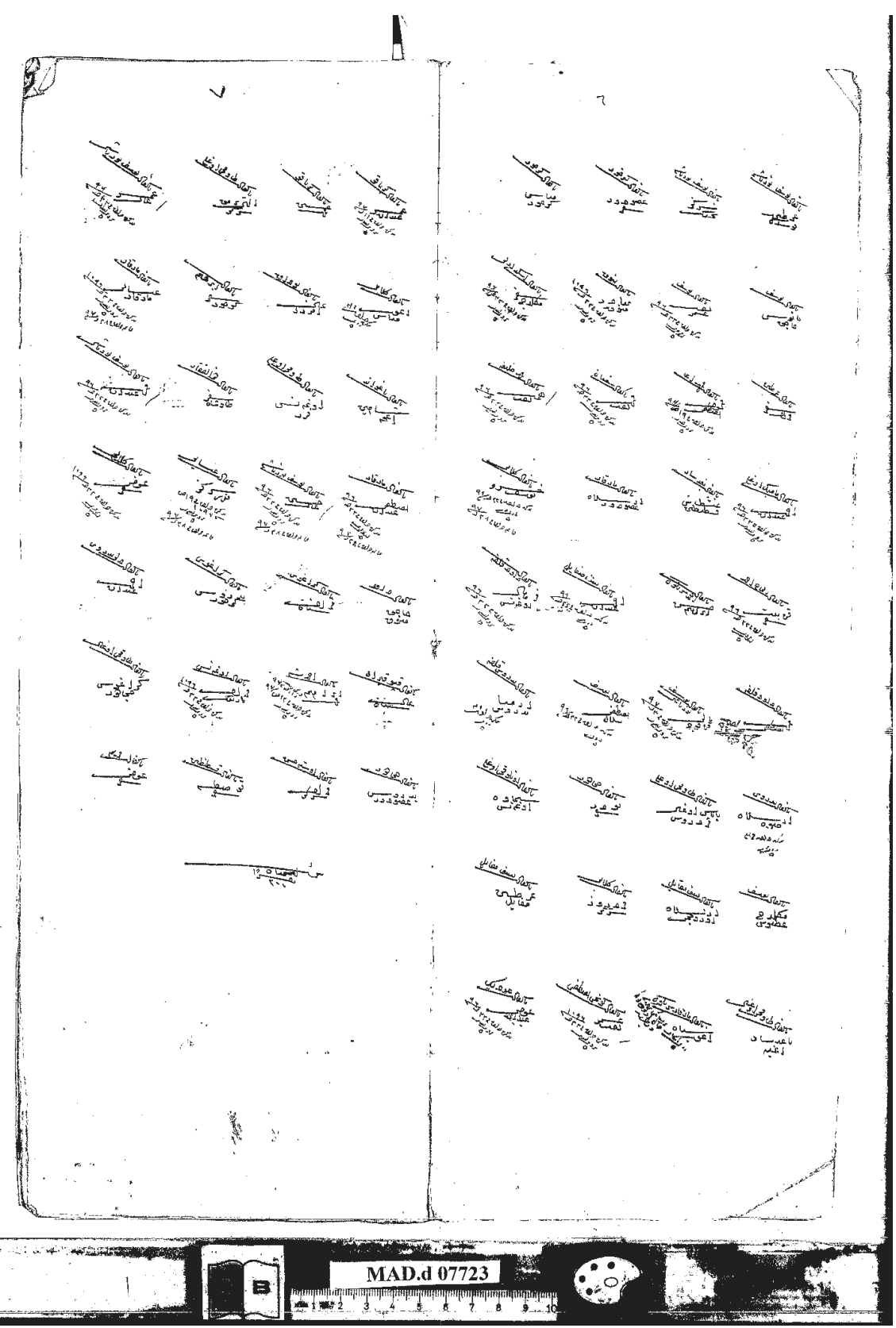




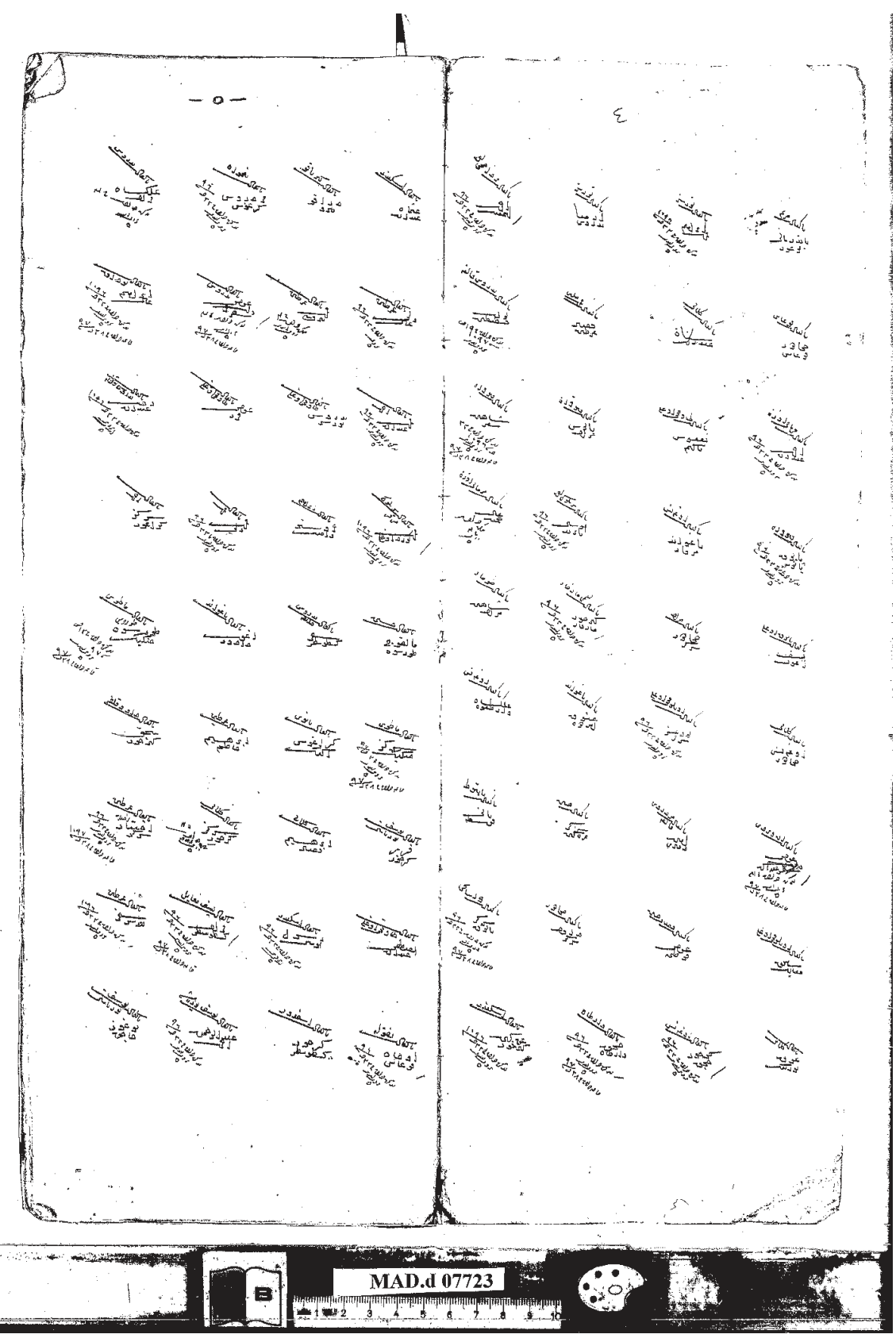


Engürüs Seferi ve Estergon Muhafazasına Katılan Geri Hizmet Birliklerine Ait

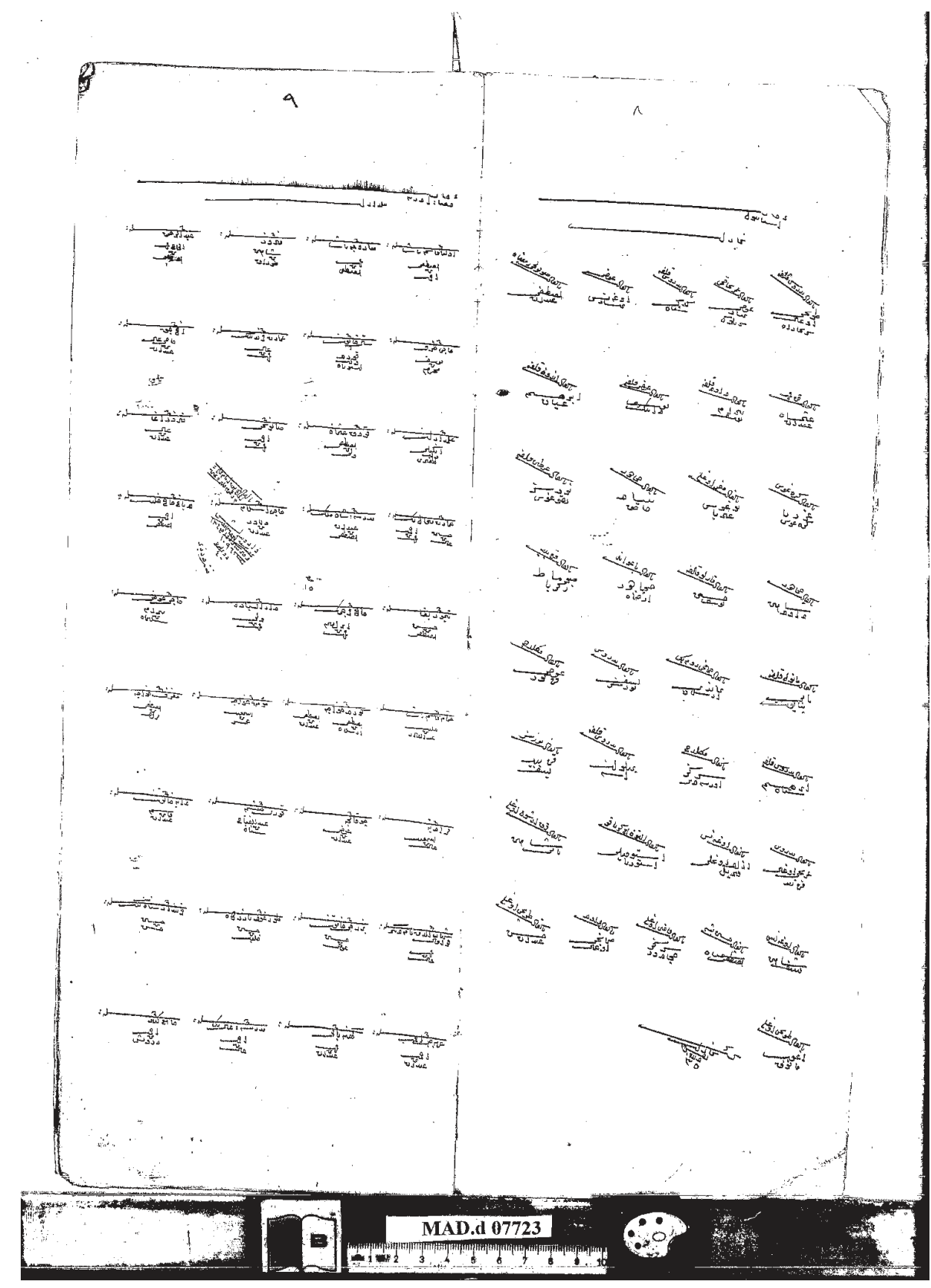




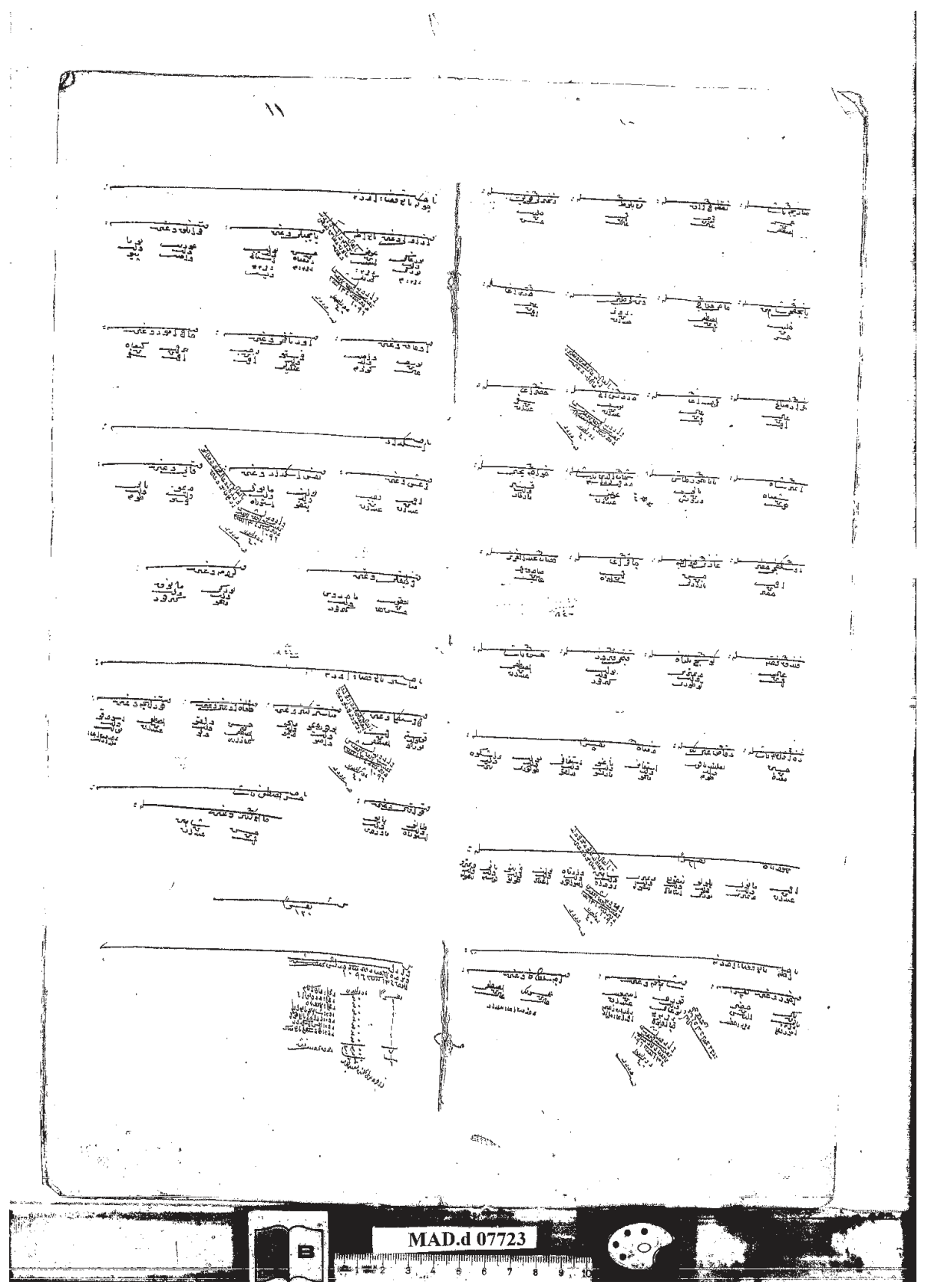


Engürüs Seferi ve Estergon Muhafazasına Katılan Geri Hizmet Birliklerine Ait

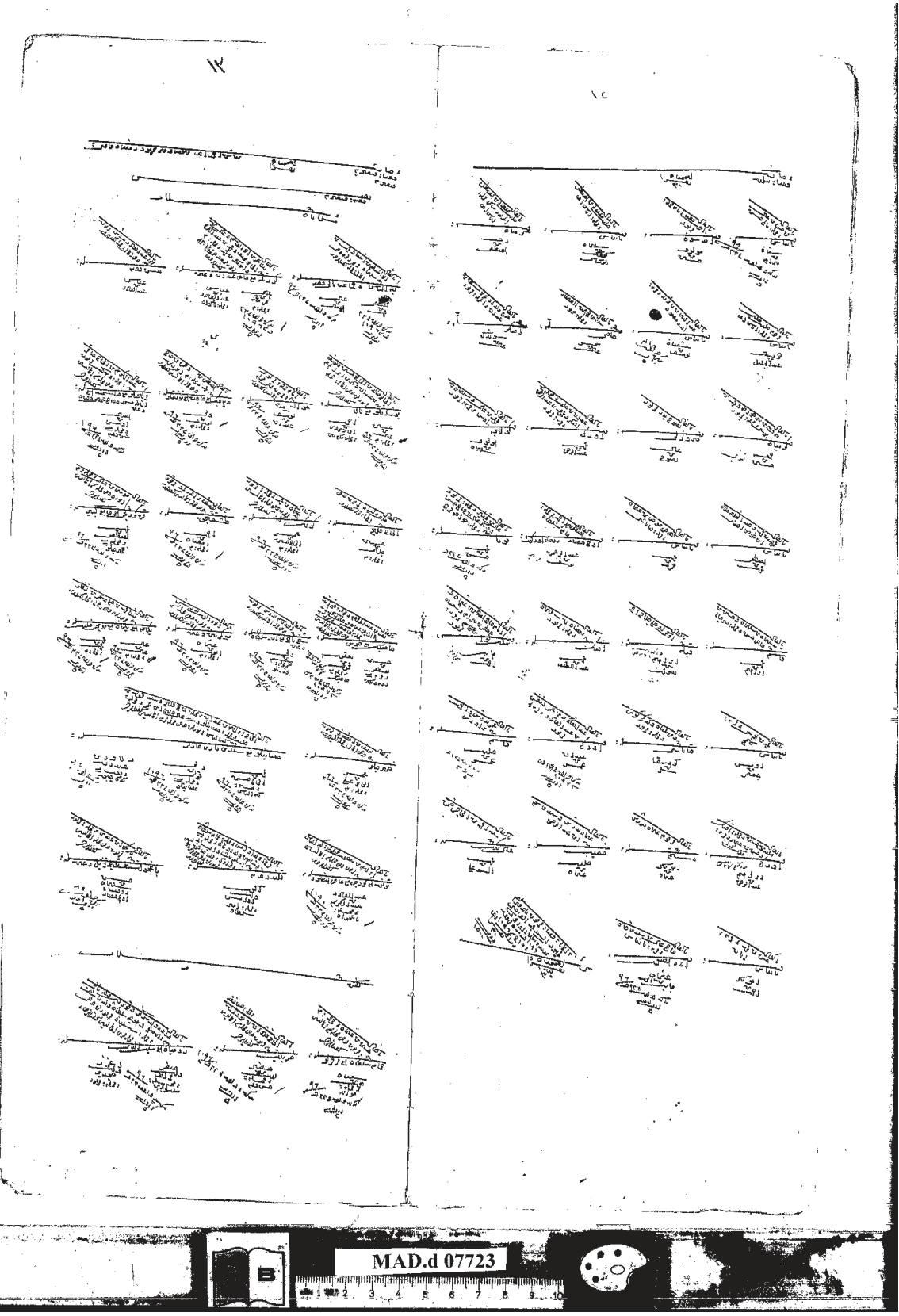




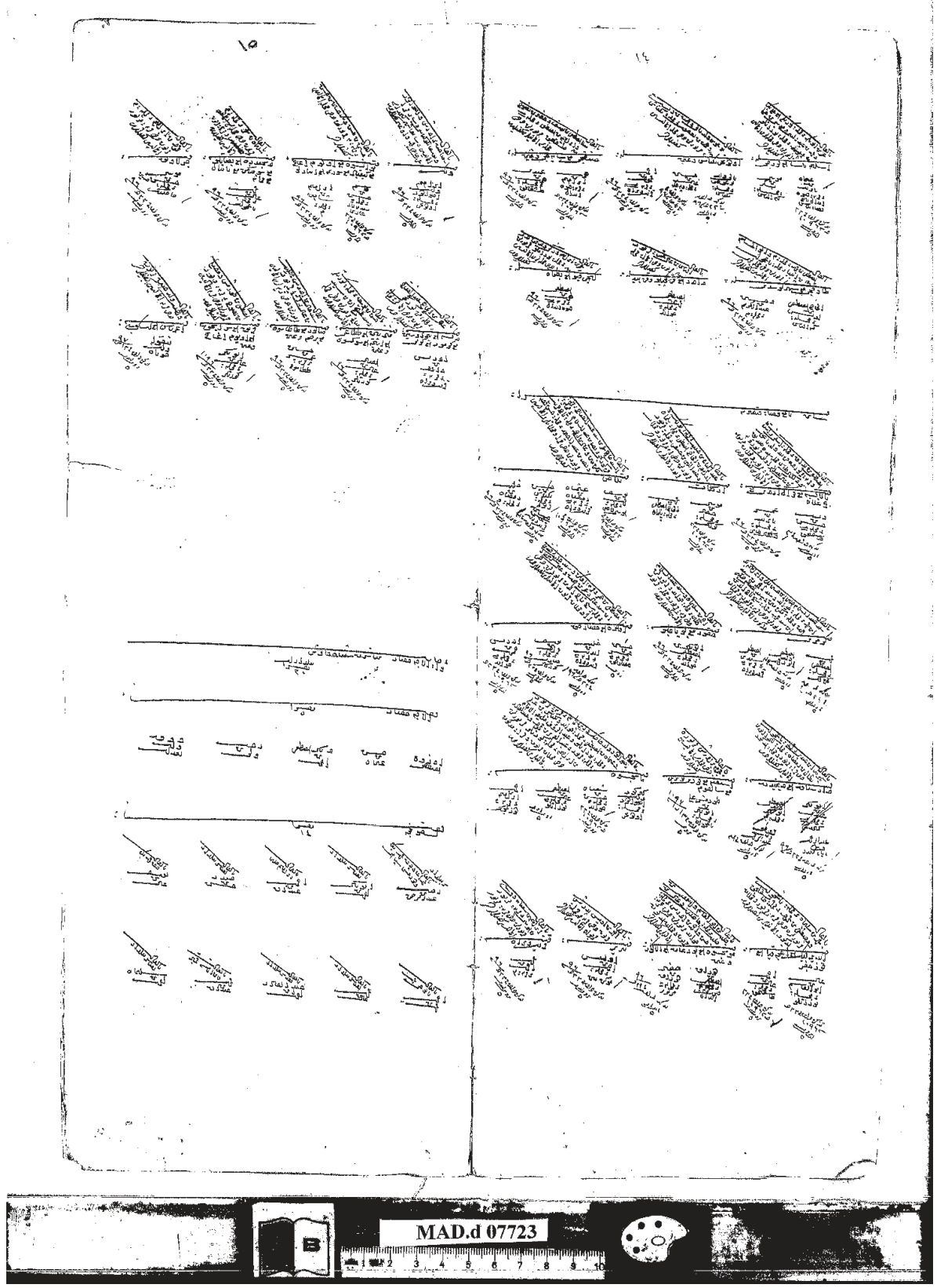


Engürüs Seferi ve Estergon Muhafazasına Katılan Geri Hizmet Birliklerine Ait 1685 Tarihli Defter

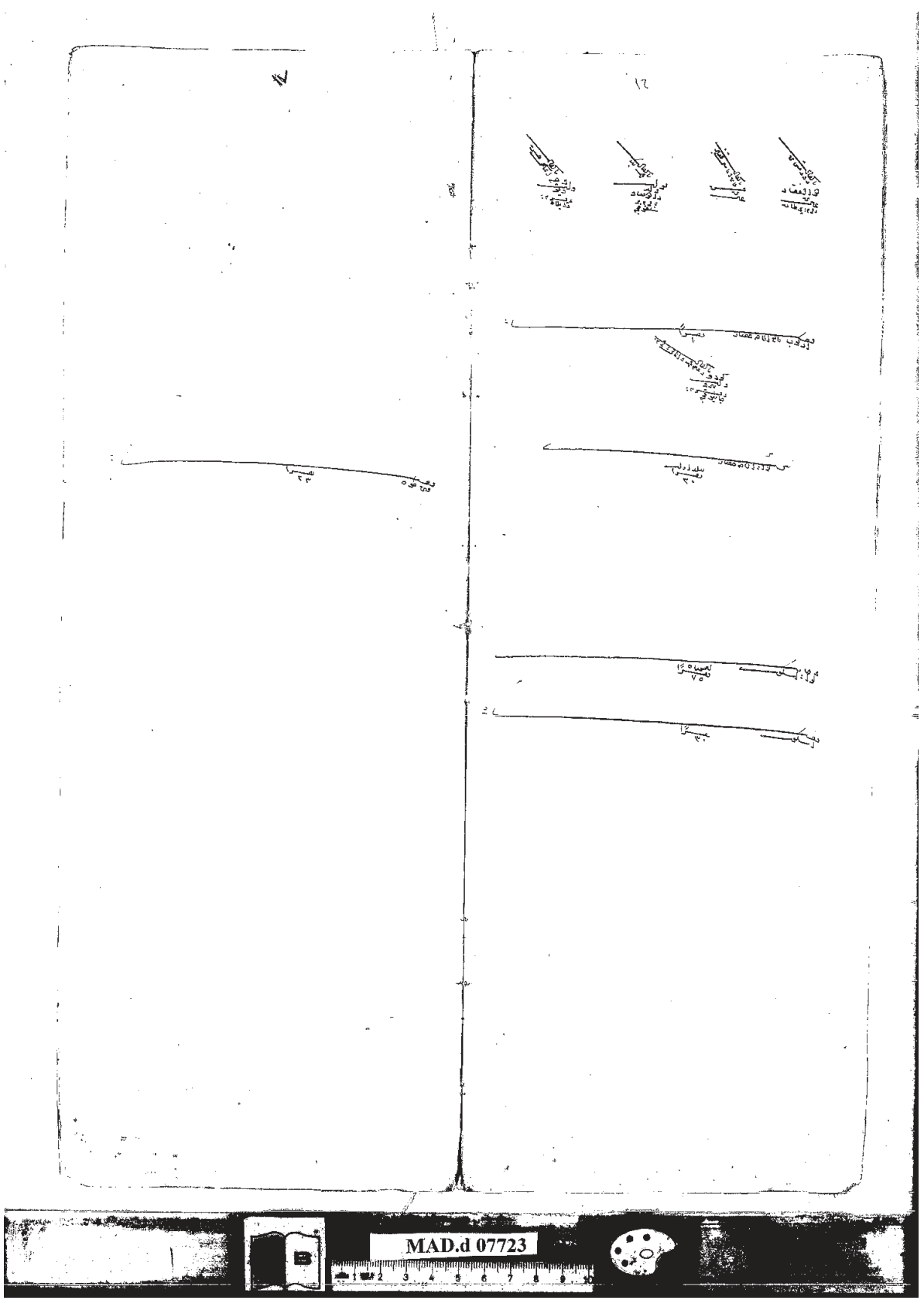




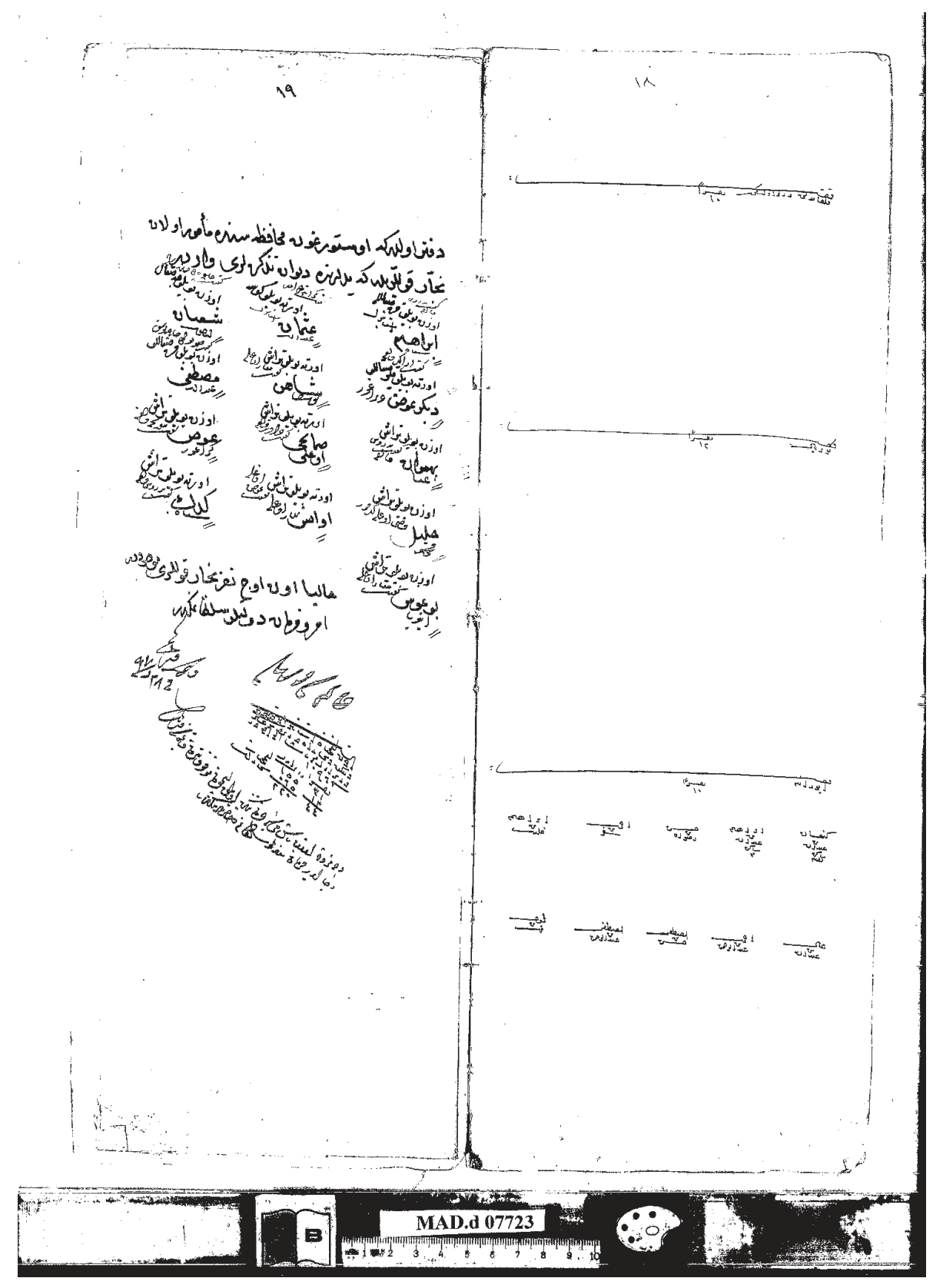


Engürüs Seferi ve Estergon Muhafazasına Katılan Geri Hizmet Birliklerine Ait

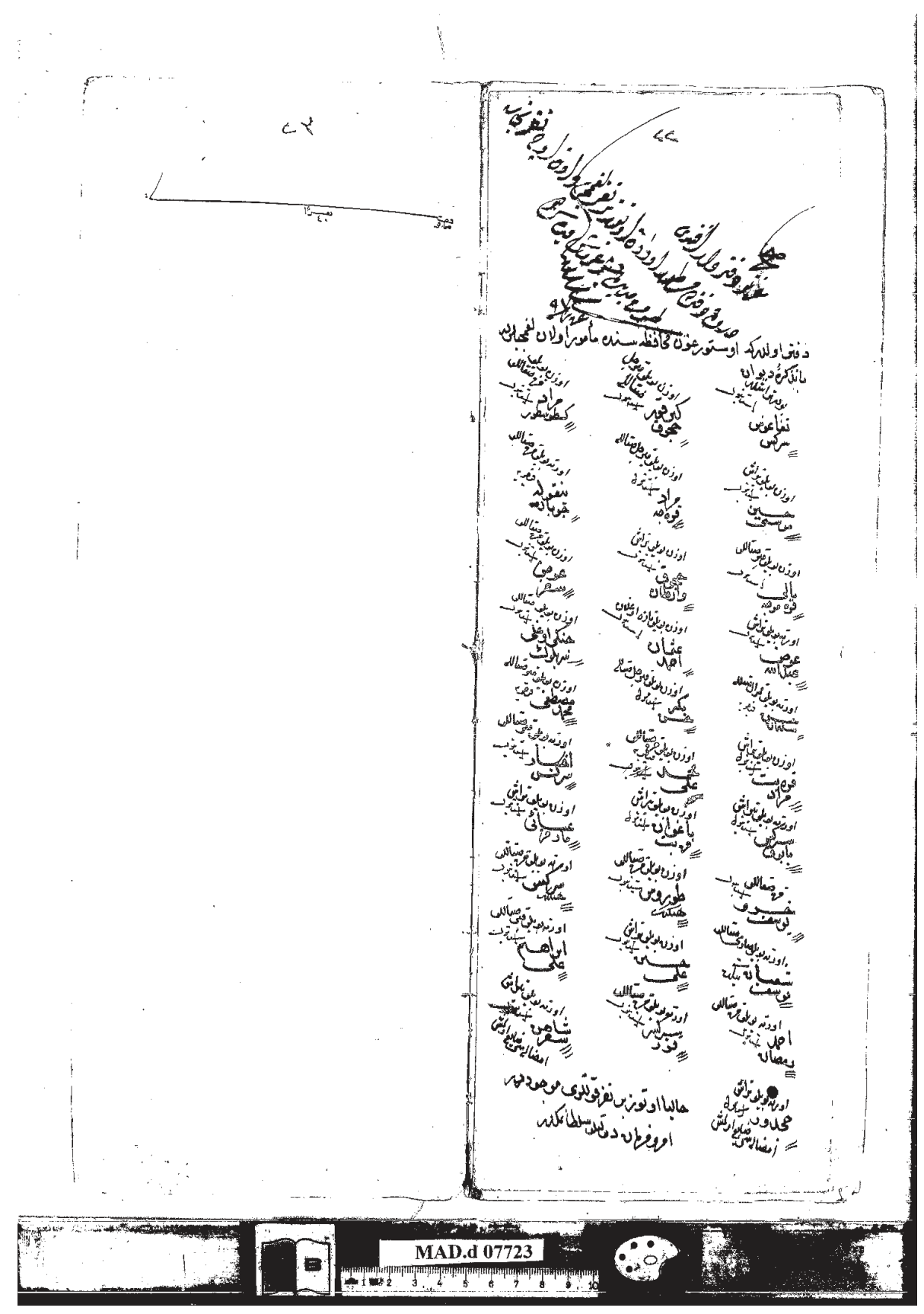



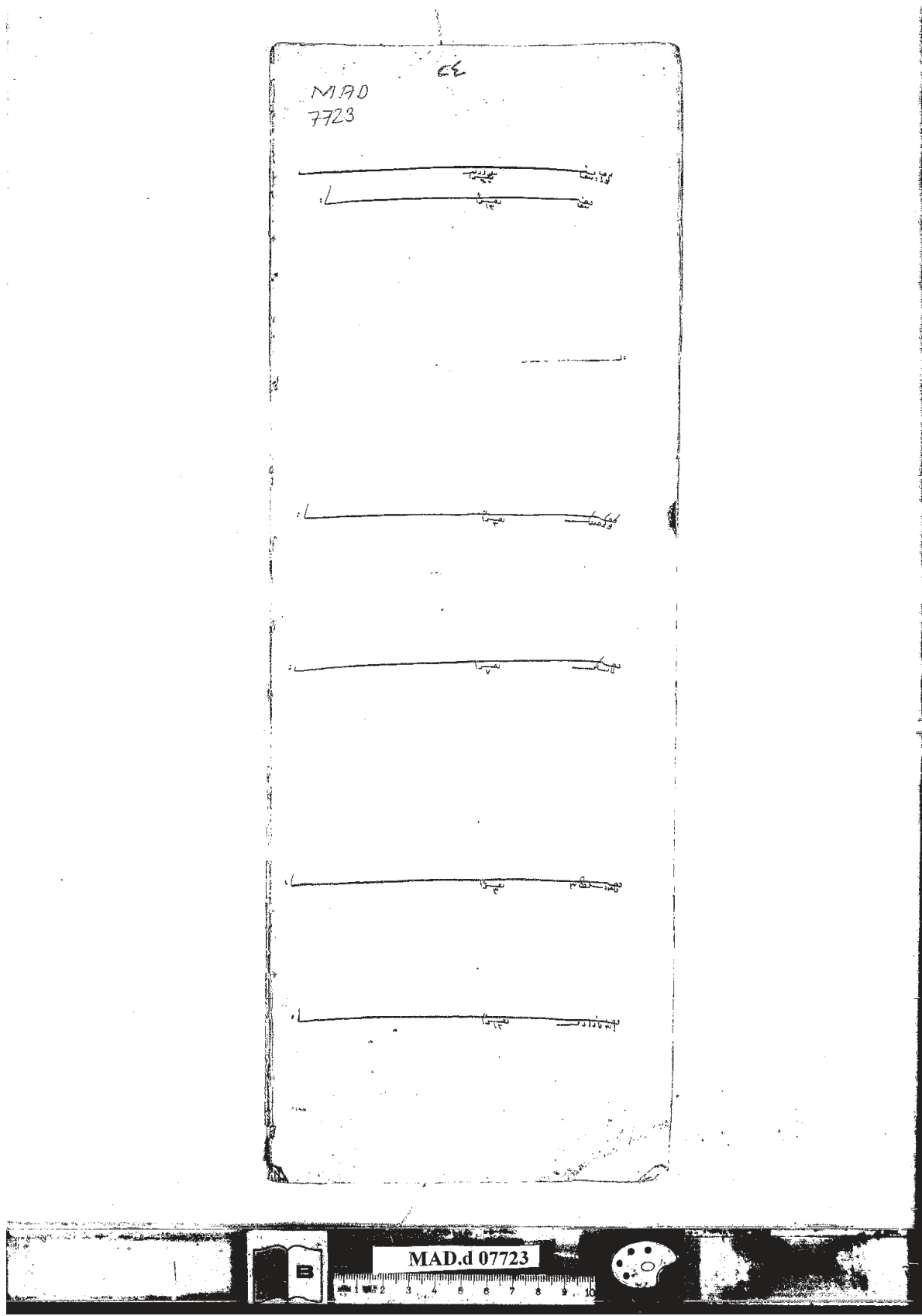